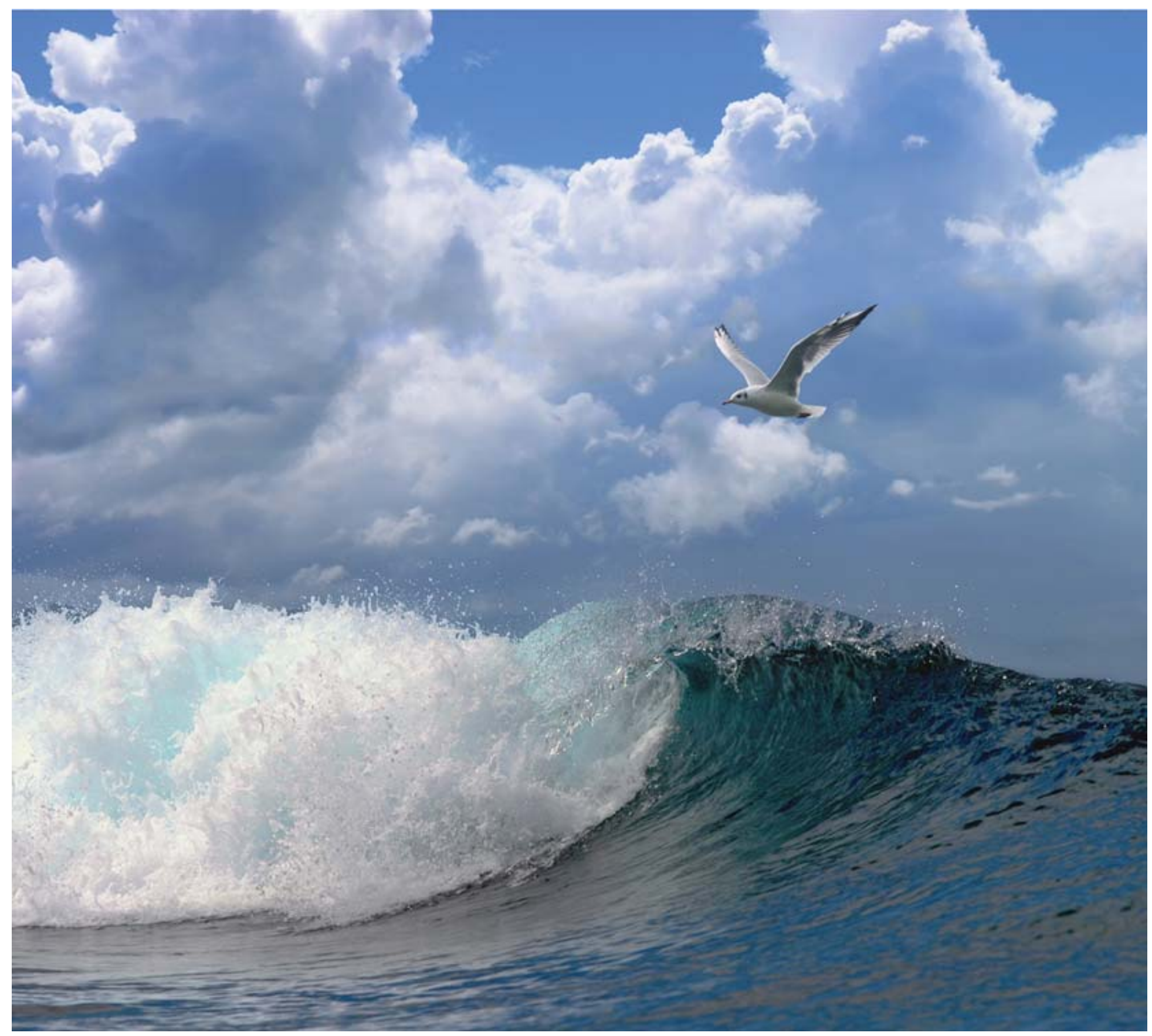

\title{
Bijvangst door innovatieve visserijmethoden voor wolhandkrab op het IJ sselmeer
}





\section{Bijvangst door innovatieve visserijmethoden voor wolhandkrab op het IJsselmeer}

Auteur(s): $\quad$ R.H. Jongbloed, M. van Hoppe, R. van Hal

Publicatiedatum: 20 september 2017

Dit onderzoek is uitgevoerd door Wageningen Marine Research in opdracht van en gefinancierd door het Ministerie van Economische Zaken, in het kader van het Beleidsondersteunend onderzoekthema 'Verduurzaming visserij' (projectnummer BO20-010-133)

Wageningen Marine Research IJmuiden, September 2017

VERTROUWELIJK Nee

Wageningen Marine Research rapport C057/17 
Jongbloed R.H., M. van Hoppe \& R. van Hal, 2017. Bijvangst door innovatieve visserijmethoden voor wolhandkrab op het IJsselmeer. Wageningen Marine Research Wageningen UR (University \& Research centre), Wageningen Marine Research rapport C057/17. 70 blz.

Keywords: Bijvangst, fuiken, korven, IJsselmeer, schubvis, duikvogels, wolhandkrab

Opdrachtgever: Ministerie van Economische Zaken

Directoraat Generaal Agro en Natuur

Directie Dierlijke Agroketens en Dierenwelzijn

T.a.v.: de heer D.J. van der Stelt

Postbus 201401

2500 EK Den Haag

BAS code BO-20-010-133

Dit rapport is vanaf 2 maanden na publicatie gratis te downloaden van

https://doi.org/10.18174/420189

Wageningen Marine Research verstrekt geen gedrukte exemplaren van rapporten.

Wageningen Marine Research Wageningen UR is ISO 9001:2008 gecertificeerd.

(C) 2017 Wageningen Marine Research Wageningen UR

Wageningen Marine Research, onderdeel van Stichting Wageningen Research KvK nr. 09098104,

IMARES BTW nr. NL 8113.83.696.B16.

Code BIC/SWIFT address: RABONL2U

IBAN code: NL 73 RABO 0373599285
De Directie van Wageningen Marine Research is niet aansprakelijk voor gevolgschade, noch voor schade welke voortvloeit uit toepassingen van de resultaten van werkzaamheden of andere gegevens verkregen van Wageningen Marine Research opdrachtgever vrijwaart Wageningen Marine Research van aanspraken van derden in verband met deze toepassing.

Dit rapport is vervaardigd op verzoek van de opdrachtgever hierboven aangegeven en is zijn eigendom. Niets uit dit rapport mag weergegeven en/of gepubliceerd worden, gefotokopieerd of op enige andere manier gebruikt worden zonder schriftelijke toestemming van de opdrachtgever. 


\section{Inhoud}

Samenvatting

$1 \quad$ Inleiding

$2 \quad$ Kennisvraag

$3 \quad$ Voorbereiding van het onderzoek $r$

$3.1 \quad$ Criteria en procedure in de voorbereiding 12

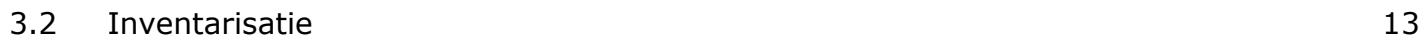

$\begin{array}{ll}3.3 & \text { Open inschrijving } \\ 3.4 & 13\end{array}$

3.4 Selectie voor deelname 13

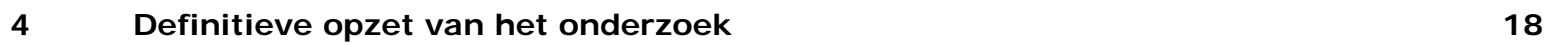

$\begin{array}{lll}4.1 & \text { Voorbereiding } & 19\end{array}$

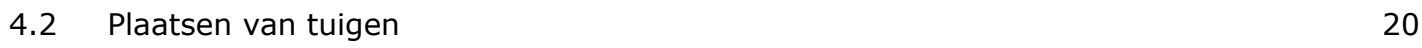

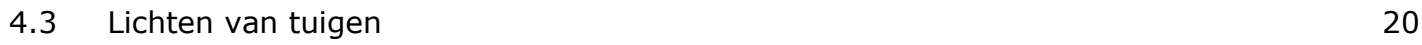

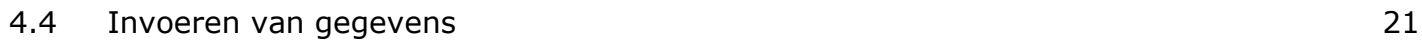

4.5 Aanvullende methoden voor Waarnemers $\quad 22$

$\begin{array}{lll}4.6 & \text { Kwaliteitsborging } & 22\end{array}$

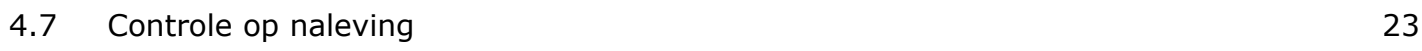

$\begin{array}{llr}5 & \text { Resultaten } & 24\end{array}$

$\begin{array}{lll}5.1 & \text { Geteste vistuigtypen } & 24\end{array}$

$\begin{array}{lll}5.2 & \text { Vangstregistratie door vissers } & 25\end{array}$

$\begin{array}{lll}5.3 & \text { Vangstregistratie door waarnemers } & 31\end{array}$

$\begin{array}{lll}5.4 & \text { Vergelijking vangstregistratiemethoden } & 42\end{array}$

6 Discussie, conclusies en aanbevelingen $\quad 47$

6.1 Wel en niet onderzochte vistuigtypen 4

$\begin{array}{lll}6.2 & \text { Onderzoeksperiode } & 47\end{array}$

$\begin{array}{lll}6.3 & \text { Bruikbaarheid en betrouwbaarheid van de gegevens } & 47\end{array}$

6.4 Vergelijking tussen gegevens van de vissers in het VRS en van waarnemers 48

$\begin{array}{lll}6.5 & \text { Ervaringen met VRS } & 48\end{array}$

$\begin{array}{lll}6.6 & \text { Bijvangst van vogels } & 49\end{array}$

6.7 Vergelijking met ander onderzoek met aangepaste hokfuiken en schietfuiken 50

6.8 Fuikenvisserij druk van onderzoek en visserijdruk van andere fuikenvisserij op het IJsselmeer $\quad 50$

6.9 Schaalgrootte en bestanden van commerciële schubvis op het IJsselmeer 51

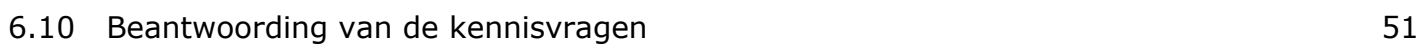

6.11 Aanbevelingen $\quad 53$

$\begin{array}{llr}7 & \text { Kwaliteitsborging } & 55\end{array}$

$8 \quad$ Literatuur $r 5$

Bijlage 1 Antwoordformulier bij de brief I nventarisatie pilot experiment wolhandkrabvisserij op IJ sselmeer

Bijlage 2 Kaart van het IJ sselmeer met indeling van de regio's 60 
Bijlage 6 Tijdschema wolhandkrabvisserij onderzoek volgens de vergunning en daadwerkelijk gevist 


\section{Samenvatting}

\section{Achtergrond en doelstelling}

Het ministerie van Economische Zaken (EZ) wil de visserij op het IJsselmeer meer perspectief bieden door mogelijkheden te verkennen gericht op wolhandkrab te vissen. Daarbij moet echter worden voorkomen dat hierdoor, via ongewenste bijvangst, een te grote visserijdruk op het schubvis- en aalbestand ontstaat. De huidige gangbare vistuigen voor wolhandkrab zijn verlaagd staandwant, schietfuik en grote fuik(hokfuik), waarbij de fuiken zijn voorzien van aanpassingen (grotere maaswijdte of een PVC buis) zodat bijgevangen aal kan ontsnappen. Deze aanpassingen zijn echter niet bemeten op een ontsnapping van schubvis (baars, snoekbaars, blankvoorn, brasem). Dit was de aanleiding voor EZ om opdracht te geven aan WMR een grootschalig experimenteel onderzoek te verrichten naar innovatieve vistuigentypen voor de wolhandkrabvisserij met een zo laag mogelijke bijvangst van schubvis en behoud van mogelijkheden om aal te laten ontsnappen. De vermijding van bijvangst van duikvogels is vanuit natuurbeschermingsoogpunt ook belangrijk. Voor het onderzoek zijn beroepsvissers ingeschakeld met daarbinnen een waarnemersprogramma uitgevoerd door WMR en ATKB. Dit onderzoek vond plaats gedurende 2016, waarbij er niet gevist mocht worden in de gesloten periode vanwege de paaiperiode van schubvis.

\section{Aanpak}

$\mathrm{Er}$ is een brief naar alle beroepsvissers van het IJsselmeer en het Markermeer gestuurd om te inventariseren wat de ideeën waren over selectieve aanpassingen aan bestaande vistuigtypen, nieuwe vistuigtypen en de belangstelling voor deelname aan het onderzoek. Na analyse en rubricering van de gegevens uit de inventarisatie is er een open inschrijving geweest voor de beroepsvissers betreffende het type en aantal vistuigen en vislocaties, waarmee ze deel zouden willen nemen in het experiment. Op de respons zijn selectiecriteria toegepast om te komen tot een verantwoorde opzet van het onderzoek met de volgende 5 vistuigtypen:

- Aangepaste hokfuik

- Aangepaste schietfuik (met en zonder buis)

- Aangepast staandwant

- $\quad$ Platliggend net (nieuw vistuigtype voor het IJsselmeer)

- Krabben- of kreeftenkorf (nieuw vistuigtype voor het IJsselmeer)

Uiteindelijk is er in het onderzoek door 4 vissers gevist met één van de volgende vistuigtypen:

- Aangepaste hokfuik (EH22)

- Aangepaste schietfuik (zonder buis) (VD94, GM29) (Dus 2 vistuig-schip combinaties)

- Krabben- of kreeftenkorf (nieuw vistuigtype voor het IJsselmeer) (WON1)

\section{Registratie en controle}

Vanwege het belang van een real time controle van het onderzoek ten behoeve van de naleving van de regelgeving heeft WMR voor dit onderzoek een gebruikersovereenkomst voor digitale visvangstregistratie (VRS) afgesloten met Natuurnetwerk. De deelnemende vissers hebben een licentie gekocht bij Natuurnetwerk waarmee hun visserijactiviteiten en de vangsten van wolhandkrab, commerciële vissoorten (baars, snoekbaars, blankvoorn, brasem, aal) en duikvogels kon worden geregistreerd in het VRS. Het beveiligingsbedrijf G4S is ingehuurd voor het uitvoeren van een aantal onaangekondigde netcontroles en aanlandcontroles bij vissers die deelnamen aan dit onderzoek. Iedere visser is door de controleurs van G4S enkele keren bezocht, waarbij geen overtredingen zijn geconstateerd.

De waarnemers van WMR of ATKB konden willekeurig opstappen bij één van de deelnemende vissers op basis van de gegevens in het VRS. De warnemers hebben de lengte van de gevangen vissen en rugschildbreedte van de wolhandkrabben gemeten en geregistreerd. 


\section{Onderzoeksperiode}

De gehele periode waarin er in dit onderzoek kon worden gevist, is door de vissers grotendeels, maar niet volledig benut. De motivatie bij dat laatste was op die momenten naar verwachting te geringe wolhandkrabvangst of de voorkeur voor een andere commercieel aantrekkelijkere vorm van visserij.

\section{Type resultaten}

Er kon geen statistische vergelijking tussen vangtuigtypen worden gemaakt van de selectiviteit (vangst-bijvangst ratio's) vanwege te weinig metingen (n) en verschil in vislocaties. Er zijn veel data verzameld, waarvan duidelijke overzichten zijn gemaakt, zoals voor (bij)vangstgegevens per vistuigtype en visreisdatum, en ook gepoold per vistuigtype over de duur van de hele pilot voor zowel VRS als de waarnemersreizen. Resultaten zijn gepresenteerd en geanalyseerd voor de visserijlocaties, visserijinspanning, vangst van wolhandkrab, bijvangst van vis, soortensamenstelling van vis, verhouding van bijvangst t.o.v. vangst van wolhandkrab, en bijvangst van vogels. Er is daarbij ook een vergelijking gemaakt tussen beide registratiemethoden.

\section{Vangst van wolhandkrab en bijvangst van vis}

Er is veel inzicht verkregen in de vangst van wolhandkrab en de omvang, soortsamenstellingen en lengteverdeling van de bijvangst van vis. De vangst aan wolhandkrab en vis per visserijinspanning verschilde sterk tussen de vistuigtypen (korf, hokfuik, schietfuik). Er zijn 28 schubvissoorten bijgevangen, waarbij er slechts enkele soorten zijn die in kwantitatieve zin, zowel aantal als gewicht, de bijvangst grotendeels bepalen. Dit zijn baars, snoekbaars, blankvoorn, bot, pos, en zwartbekgrondel. Daarvan zijn er bij elk van de 4 onderzochte vistuig-schip combinaties slechts 2 vissoorten die op basis van aantal de bijvangst domineren. Dit zijn pos en zwartbekgrondel bij korfWON1 en schietfuik-GM29, baars en zwartbekgrondel bij schietfuik-VD94, baars en pos bij hokfuikEH22. De commerciële schubvissoorten baars, snoekbaars, blankvoorn hebben alleen bij de hokfuiken een belangrijk aandeel in de totale bijvangst. Met korven en hokfuiken wordt bijna alleen kleine vis bijgevangen, terwijl met schietfuiken ook veel grotere vis wordt bijgevangen.

\section{Verhouding tussen bijvangst van vis en vangst van wolhandkrab}

De verhouding tussen de bijvangst van vis en de vangst van wolhandkrab is berekend voor alle 4 vistuig-schip combinaties. Hierbij kwamen grote verschillen naar voren tussen deze combinaties. De bijvangst van vis relatief ten opzichte van wolhandkrab is het grootste in hokfuik en schietfuik van de GM29. De bijvangst is het kleinste in korven. De bijvangst is intermediair in de schietfuiken van VD94. Er wordt een groot verschil in bijvangst geconstateerd tussen de schietfuiken van de VD94 en de GM29. Er zijn twee verschillen tussen de beide schietfuik-schip combinaties die een grote rol bij dit verschil zouden kunnen spelen. Circa de helft van de schietfuiken van de GM29 had een andere netaanpassing, namelijk een grootmazige ruif in plaats van een grootmazige achterste kub. Wellicht dat de ontsnapping van vis beperkter is in een ruif vanwege de beperkte afmeting van die ruif. Een ander verschil betreft de vislocaties met de daaraan gekoppelde verschillen in dichtheden van wolhandkrab, schubvis, waterdiepte, e.d.. Dit zijn echter alleen veronderstellingen.

\section{De invloed van seizoen en locatie op vangst en bijvangst}

Er zijn geen grote verschillen in vangst en bijvangst tussen de seizoenen geconstateerd. Dit werd niet verwacht omdat algemeen bekend is dat de vangst van wolhandkrab meestal verreweg het grootste is in het najaar. Echter de opzet en de omvang van dit onderzoek was te beperkt om harde conclusies te trekken. Voor de invloed van seizoenen binnen een jaar is monitoring gedurende een aantal jaren nodig, vanwege de variatie in bestanden van wolhandkrab en vissen.

\section{Bijvangst van vogels}

Er is belangrijk inzicht verkregen in de bijvangst van vogels. Er trad namelijk bijvangst van een aantal vogels op in hokfuiken en schietfuiken, terwijl van tevoren niet werd verwacht dat de bijvangstkans in fuiken op het IJsselmeer zo groot zou kunnen zijn. Het aantal waarnemingen is echter dermate gering zodat onvoldoende beeld verkregen kon worden van de kans op bijvangst van vogels. Bijvangst van vogels in fuiken blijkt wel een reële bedreiging voor met name de instandhoudingsdoelstelling van de fuut te zijn. Ook de relatief grote kans op bijvangst van aalscholvers in aangepaste hokfuiken is een punt van zorg. 


\section{Vergelijking van resultaten geregistreerd door waarnemers en geregistreerd door vissers in}

het digitale visregistratiesysteem (VRS)

De mate van overeenkomst tussen resultaten die zijn geregistreerd door waarnemers in hun eigen systeem en resultaten die door de vissers zijn ingevoerd in het digitale visregistratiesysteem (VRS) is redelijk voor de wolhandkrabvangst en over het algemeen matig voor bijvangst van vis, waarbij deze varieert per vissoort. De verhouding tussen de bijvangst en de vangst verschilt tussen de beide registratiemethoden over het algemeen een factor 2 , met een matige correlatie. VRS lijkt daarmee wel geschikt om een globaal beeld te krijgen van vangst en bijvangst in de wolhandkrabvisserij, maar de afwijkingen met de waarnemers zijn soms aanzienlijk, o.m. vanwege het lagere detailniveau en daarmee is VRS niet geschikt voor wetenschappelijke doeleinden. De ervaringen met de digitale visvangstregistratie door de vissers in het VRS zijn dat de vissers het soms onduidelijk en bewerkelijk vonden om er mee te werken, terwijl er een enkele keer ook storingen in het VRS optraden. VRS is wel een geschikte tool voor inzicht in de concrete visserijactiviteiten.

\section{De selectiviteit van nieuwe en aangepaste vistuigtypen voor de wolhandkrabvisserij op het IJ sselmeer}

Alle 3 vistuigtypen zijn selectief voor de vangst van wolhandkrab, maar in verschillende mate. De verschillen zijn soms groot, maar zijn niet statistisch getoetst, omdat de opzet van het onderzoek zich daarvoor niet leende. De vraag blijft echter of deze selectiviteit voldoende of acceptabel is. Er zijn echter geen objectieve criteria voor een acceptabel niveau van selectiviteit van vistuigen. In geval subjectieve criteria worden gekozen, is de bijvangst klein in korven, matig in hokfuiken, en klein tot groot in schietfuiken, op basis van de metingen van de waarnemers. Uitgaande van de registraties van de vissers is de bijvangst klein in korven, klein in hokfuiken, en klein tot matig in schietfuiken.

\section{Aanbevelingen}

Op basis van de resultaten van dit onderzoek worden er een aantal aanbevelingen voor nader onderzoek gedaan. Bij de bespreking van de resultaten van dit onderzoek met de deelnemende vissers bleek dat er nog veel aanvullende ideeën zijn en dus ruimte voor verdergaande verbetering en innovatie. Deze aanbevelingen en aanvullende ideeën worden hieronder kort benoemd.

- Keerwant in fuiken voor reductie van bijvangst van vogels, vergelijkbaar met de keerwant die verplicht is gesteld in de fuikenvisserij in de kustwateren.

- Draden die worden gespannen voorin de fuik. De verwachting is dat deze draden wel duikvogels, maar niet wolhandkrabben afschrikken om de fuik binnen te gaan.

- Draden die worden gespannen aan de buitenzijde van de ontsnappingsbuis zouden duikvogels, zoals aalscholvers, kunnen afschrikken door de buis de fuik in gaan.

- De bevestiging van afschriklinten aan de palen van hokfuiken zou een effectieve mitigerende maatregel voor vogels kunnen zijn.

- Nader onderzoek met onderwatercamera's om het gedrag van aalscholvers bij de hokfuiken, met en zonder de bovengenoemde mitigerende maatregelen, te onderzoeken.

- De overleving van schubvis die worden bijgevangen in hokfuiken kan worden verbeterd met een "opvangzak" waarin de vangst wordt geleegd en de kleine schubvis kan ontsnappen. De werking is naar verwachting analoog aan de overlevingsbun die wordt toegepast bij schietfuiken.

- De toepassing van een ruif (maaswijdte $70 \mathrm{~mm}$ ) aan de bovenkant en de onderkant van het middelste gedeelte van hokfuik en schietfuik biedt de daar zich soms massaal ophopende kleine schubvis een extra mogelijkheid te ontsnappen.

- Schietfuiken met een achterste kub die geheel uit grofmazig netwerk bestaan, zijn voor de beoogde ontsnapping van schubvis waarschijnlijk veel effectiever dan schietfuiken met de grofmazige ruif in de achterste kub.

- Controleren of de mazen van de achterste kub na het schieten van de fuiken wel voldoende open staan om daarmee de ontsnapping van kleine schubvis voldoende mogelijk te maken. Zo nodig moet de constructie van het netwerk worden aangepast om het doel wel te bereiken.

- Testen van korven op andere locaties in het IJsselmeer

- Studie naar invloed van opschaling van wolhandkrabvisserij op schubvisbestanden van het IJsselmeer. 
- Adaptief beheer \& systematische verbetering die aan kunnen sluiten en meegenomen kunnen worden bij de "Plan B" benadering van de IJsselmeervissers, waarvoor de Staatssecretaris recent groen licht heeft gegeven - onder voorwaarden. 


\section{$1 \quad$ Inleiding}

\section{Achtergrond}

De Chinese wolhandkrab (Eriocheir sinensis) komt oorspronkelijk uit China, maar komt nu op vele plekken ter wereld, waaronder Nederland, massaal voor. Aanvankelijk werd de wolhandkrab door vissers en waterschappen gezien als een plaag, maar de Nederlandse binnenvisserij ontdekte rond 2000 dat China een belangrijke markt was voor wolhandkrab. Recent is ook op de internationale markt de vraag naar de wolhandkrab sterk gestegen. In de afgelopen jaren is de prijs per $\mathrm{kg}$ wolhandkrab gestegen naar gemiddeld circa 16 euro per kg (Bron: Afslag Urk). Met de wolhandkrab kunnen aanvullende bronnen van inkomen worden gegenereerd, die de Nederlandse binnenvisserij sector nieuwe impulsen kan bezorgen. Betrokkenen in de sector zien de wolhandkrab als lucratieve nieuwe markt.

De vangst van wolhandkrab varieert sterk van jaar tot jaar. Binnen het jaar wordt normaliter de meeste wolhandkrab gevangen tijdens de migratieperiode, dat is met name in het najaar (september t/m november) en in mindere mate geldt dat ook voor de maand mei. (Bakker \& Zaalmink, 2012; Soes et al., 2007).

Er zijn enkele experimenten uitgevoerd naar de bijvangst van schubvis in de visserij die was gericht op de vangst van wolhandkrab. Dit betreft experimenten met aangepaste hokfuiken en schietfuiken (Heinen, 2012; Leijzer et al., 2008), een experiment met aangepaste schietfuiken (Kampen, 2014) en een experiment met laag staandwant (Kampen, 2015). De omvang van de bijvangst van schubvis bleek gering te zijn. Deze experimenten waren echter beperkt van opzet betreffende het aantal geteste vistuigtypen, aantal visreizen en de duur van de visserijperiode in het jaar. Er werden geen nieuwe vistuigtypen getest, terwijl daar ook behoefte aan is om inzicht te krijgen in de mogelijkheden om vistuigtypen in te zetten waarmee er nog minder bijvangst kan optreden.

De huidige gangbare vistuigen voor wolhandkrab op het IJsselmeer zijn verlaagd staand want, schietfuik en grote fuik (hokfuik). Sinds kort is een beleidsregel in werking getreden die het mogelijk maakt te vissen op wolhandkrab in de aalgesloten periode (september $\mathrm{t} / \mathrm{m}$ november) en daarvoor moeten de vissers voldoen aan een aantal voorwaarden. Hiervan wordt door een aantal beroepsvissers op het IJsselmeer gebruik gemaakt. De fuiken voor de visserij in de aalgesloten periode moeten voorzien zijn van aanpassingen (grotere maaswijdte of aanbrengen van een PVC buis) zodat bijgevangen aal kan ontsnappen. Deze aanpassingen zijn echter niet bemeten op een ontsnapping van schubvis (baars, snoekbaars, blankvoorn, brasem), want daarvoor is een grotere netmaaswijdte of buisdiameter nodig.

\section{Behoefte aan dit onderzoek}

De visserijsector op het IJsselmeer en Markermeer is de laatste jaren geconfronteerd met beperkingen in de visserij op aal en schubvis. Het ministerie van Economische Zaken (EZ) wil de visserij op het IJsselmeer en het Markermeer meer perspectief bieden door de mogelijkheden te verkennen om gericht op wolhandkrab te vissen. Daarbij moet echter worden voorkomen dat de verruiming van de mogelijkheden van een gerichte wolhandkrabvisserij gepaard gaat met veel bijvangst van schubvis en aal en daarmee zorgt voor een hogere visserijdruk op het schubvis- en aalbestand. Daarom laat EZ een breed opgezet onderzoek verrichten naar vistuigen die gebruikt kunnen worden voor de wolhandkrabvisserij met een zo laag mogelijke bijvangst van schubvis en behoud van mogelijkheden om aal te laten ontsnappen.

Voor een verdere verruiming van de wolhandkrabvisserij zal experimenteel moeten worden onderzocht hoe de bijvangst van schubvis kan worden beperkt d.m.v. aanpassingen aan vistuigen of toepassing van nieuwe vistuigen waardoor er geen of weinig schubvis wordt gevangen en gevangen schubvis kan ontsnappen. De aandachtsoorten onder de schubvis zijn baars, snoekbaars, blankvoorn, brasem, vanwege hun commerciële waarde. 
De kennisvraag voor dit onderzoek is het testen van door vissers voorgestelde tuigconfiguraties betreffende vangst van wolhandkrab en bijvangst van relevante vissoorten en vogels. Eerder onderzoek (Bult et al. 2007) heeft laten zien dat de vangstverhoudingen worden beïnvloed door factoren als jaargetijde en locatie. Daarom is er in het huidige onderzoek bemonsterd in verschillende gebieden gedurende de periodes binnen één jaar waarin deze visserij is toegestaan en interessant voor de sector is. De visserij is door de vissers uitgevoerd en met hun eigen (samengestelde/aangepaste) tuigen.

Op deze manier is er in de praktijksituatie geprobeerd inzicht te krijgen in de selectiviteit van de geteste aangepaste en nieuwe vistuigen voor de vangst van wolhandkrab en de bijvangst van schubvis, aal en vogels. De vistuigtypen zijn onderling vergeleken betreffende de ratio vangst/bijvangst. De resultaten kunnen door het ministerie/EZ worden gebruikt bij de ontwikkeling van regelgeving voor de beroepsmatige wolhandkrabvisserij op het IJsselmeer.

\section{Waarom deelname van vissers?}

Er zijn een aantal beroepsvissers op het IJsselmeer die ervaring hebben met de wolhandkrabvisserij en daardoor weten wat geschikte methoden, locaties en periodes zijn voor een optimale vangst van wolhandkrab. Bovendien leven er bij de beroepsvissers ideeën over mogelijke aanpassingen aan bestaande tuigen of de inzet of ontwikkeling van nieuwe vistuigtypen om wolhandkrab te vangen. Deze nieuwe en aangepaste bestaande vistuigtypen mogen echter niet worden toegepast in het IJsselmeer omdat deze vistuigtypen niet zijn toegestaan voor de visserij op wolhandkrab op het IJsselmeer/Markermeer of niet zijn toegestaan in bepaalde perioden van het jaar. Dit onderzoek is uitgevoerd door een aantal beroepsvissers in samenwerking met WMR op basis van een ontheffing voor onderzoek door WMR. Uitgangspunt van het onderzoek was dat er voldoende draagvlak binnen de IJsselmeervisserijsector moest zijn waarbij gebruik gemaakt kon worden van de kennis van de vissers betreffende een effectieve vangst van wolhandkrab in combinatie met een beperking van de bijvangst van vis. Wageningen Marine Research (WMR) heeft de ideeën en de belangstelling van beroepsvissers voor deelname aan deze experimentele visserij op wolhandkrab geïnventariseerd. Door de samenwerking tussen de visserijsector, EZ en WMR wordt optimaal gebruik gemaakt van de aanwezige praktische (sector) en wetenschappelijke (WMR) kennis en wordt draagvlak gecreëerd voor de ontwikkeling en toepassing van vistuigtypen, waarmee bijvangst wordt beperkt tot een zeer laag niveau.

\section{Nb-wetvergunning}

Voor het onderzoek is een Nb-wetvergunning aangevraagd, waarvoor een Voortoets is uitgevoerd naar de verwachte effecten van het onderzoek op de Natura 2000-instandhoudingsdoelstellingen van het IJsselmeer (Jongbloed, 2015). In de Voortoets zijn de activiteit, de beschermende natuurwaarden volgens Natura 2000, globale beoordeling van de mogelijke verstoringstypen en de gevoeligheden van de natuurwaarden, nadere effectbeoordeling van verwachte effecten op relevante natuurwaarden, mitigerende maatregelen, en cumulatie behandeld. Er zijn ook conclusies getrokken over de verwachte gevolgen van de activiteit voor de instandhoudingsdoelstellingen.

De belangrijkste potentiele effecten van de activiteit zijn verdrinking van duikvogels in verlaagd staandwant en platliggend net en aantasting van de voedselvoorraad van visetende vogels door de bijvangst van schubvis. Van de aangepaste hokfuiken, aangepaste schietfuiken en de krabbenkorven werden in de Voortoets geen substantieel negatieve effecten op Natura 2000 instandhoudingsdoelstellingen verwacht. De verwachting was dat er door toepassing van bestaande en nieuwe mitigerende maatregelen geen significante effecten op de instandhoudingsdoestellingen van deze soorten zullen plaatsvinden, waarbij de registratie van de aantallen bijgevangen vogels in de onderzoeksmatige wolhandkrabvisserij op het IJsselmeer kunnen worden gebruikt ter verificatie van de conclusies.

De Nb-wetvergunning voor het onderzoek is aangevraagd bij de provincie Fryslân, het bevoegd gezag voor Natura 2000-gebied IJsselmeer, en is eind december 2015 verstrekt aan WMR en was geldig voor de periode 1 januari t/m 31 december 2016. 


\section{$2 \quad$ Kennisvraag}

Het doel van het onderzoek is het verkrijgen van inzicht in de visserijmethoden waarmee de mogelijkheden voor de wolhandkrabvisserij op het IJsselmeer kunnen worden vergroot, zonder dat dit een grote visserijdruk legt op bestanden van aal en schubvis. De doelgroepen zijn het ministerie van Economische Zaken en de IJsselmeervissers en indirect ook de Natuurorganisaties.

De hoofdvraag betreffende het onderzoek is: Hoe selectief zijn nieuwe en aangepaste vistuigtypen voor de wolhandkrabvisserij op het IJsselmeer?

De daarbij horende deelvragen hebben betrekking op het met experimenteel onderzoek verkrijgen van inzicht in de volgende aspecten:

1. Vangst van wolhandkrab

2. Bijvangst van vis (omvang, soortensamenstelling, lengteverdeling)

3. Verhouding tussen bijvangst van vis en vangst van wolhandkrab

4. Bijvangst van vogels

5. De invloed van seizoen en locatie op vangst en bijvangst.

6. De mate van overeenkomst tussen resultaten die zijn geregistreerd door de waarnemingen van onderzoekers en door de vissers in het digitale visregistratiesysteem (VRS) van NatuurNetwerk. 


\section{$3 \quad$ Voorbereiding van het onderzoek}

\subsection{Criteria en procedure in de voorbereiding}

Deze paragraaf geeft een korte beschrijving van de criteria, gevolgde procedure en resultaat in de voorbereidingsfase van het onderzoek. Dit is de voorbereidingsfase, de beschrijving van de uiteindelijke opzet van het onderzoek is beschreven in het volgende hoofdstuk. De uiteindelijke opzet is, door de tegenvallende deelname van het aantal vissers, minder ambitieus dan hieronder beschreven en waar vanuit was gegaan tijdens de voorbereiding.

In de voorbereiding gingen we uit van criteria om te komen tot een verantwoorde opzet van het onderzoek en de selectie van typen en aantallen vistuigentypen, vissers, e.d.. Deze criteria waren:

1. Het onderzoek moet wetenschappelijk verantwoord zijn. De wijze waarop het onderzoek is vormgegeven moet vanuit een wetenschappelijke opzet ingestoken en verdedigbaar zijn.

2. Er wordt, tenzij expliciet en specifiek anders bepaald in het kader van dit onderzoek, niet getornd aan bestaande regels voor IJsselmeervisserij, zoals minimale afstanden (200 m/50 m) van plaatsen van schietfuiken ten opzichte van hokfuiken, en dergelijke.

3. Controleerbaarheid van het onderzoek is voldoende/overtuigend.

4. Zo veel mogelijk vissers en viscapaciteit als mogelijk (binnen wat wettelijk, wetenschappelijk verantwoordbaar en binnen natuurbeheerdoelstellingen redelijkerwijs is toegestaan) deel laten nemen.

De insteek van EZ was om alle beroepsvissers de kans te gegeven deel te nemen aan het onderzoek, vandaar dat er als eerste een inventarisatie onder de beroepsvissers is gedaan naar mogelijke interesse in deelname en mogelijke vangsttechnieken (zie bijlage 1). Op basis van de door de beroepsvissers voorgestelde vangsttechnieken is er een lijst van vangsttechnieken opgesteld waarop beroepsvissers zich, via een open inschrijving, konden aanmelden. Inschrijven voor meerdere vangsttechnieken was ook mogelijk en de vissers konden aangeven waar ze de visserij met deze techniek zouden willen uitvoeren waarbij het IJsselmeer en Markermeer waren opgedeeld in verschillende regio's (Bijlage 2). Deze acties hebben geleid tot een beperkte lijst van beroepsvissers en vistechnieken. Daarna zijn de definitieve voorwaarden, waaraan voldaan moest worden voorgelegd aan de beroepsvissers en is een contract opgesteld om de deelname te bekrachtigen. Uiteindelijk hebben vier beroepsvissers mee gedaan aan de uitvoering van het onderzoek. De stappen in dit proces van de inventarisatie, selectie en uiteindelijke deelname en de bijbehorende aantallen vissers zijn weergeven in Tabel 1.

Tabel 1 Het proces van de inventarisatie van de belangstelling voor deelname tot en met de huidige deelname van vissers in het onderzoek en de bijbehorende aantallen vissers.

\begin{tabular}{|l|c|c|c|}
\hline Stap in proces & Periode & Aantal vissers & $\begin{array}{c}\text { Aantal } \\
\text { vistuigtypen }\end{array}$ \\
\hline Belangstellende vissers in de inventarisatie & jul/15 & 29 & 9 \\
\hline Open inschrijving door vissers & sep/15 & 15 & 6 \\
\hline Geselecteerde vissers voor deelname & nov/15 & 12 & 6 \\
\hline $\begin{array}{l}\text { Belangstellende vissers van de geselecteerde } \\
\text { vissers }\end{array}$ & dec/15 & 10 & 6 \\
\hline Contract aangeboden aan vissers & jan/16 & 10 & 4 \\
\hline Contract ondertekend door vissers & jan/16 \& feb/16 & 4 & 4 \\
\hline Actieve deelname door vissers aan het onderzoek & jan/16 t/m dec/16 & 4 & 3 \\
\hline
\end{tabular}




\subsection{Inventarisatie}

Het project is gestart in mei 2015 met voorbereidende besprekingen tussen EZ en Wageningen Marine Research over de opzet van een experiment naar de wolhandkrabvisserij en de voorbereiding daarvan. Een belangrijk onderdeel van die voorbereiding was de inventarisatie naar de belangstelling voor deelname bij beroepsvissers met een vergunning voor aalvisserij en/of schubvisserij op het IJsselmeer. EZ heeft de brief met deze inventarisatie op 9 juli 2015 naar deze vissers gestuurd. WMR heeft de reactie van de vissers geanalyseerd, waarbij de aangedragen vistuigtypen zijn gerubriceerd en beoordeeld op voldoende ontsnappingsmogelijkheid voor schubvis. Van de 9 rubrieken vistuigen zijn er 2 afgevallen omdat er te weinig vertrouwen was in die laatsten.

Het aantal belangstellende vissers was op dat moment dusdanig groot dat het aannemelijk was dat elke rubriek van vistuigtypen/-varianten in het onderzoek zou kunnen worden getest. Het uiteindelijke aantal vissers kon nog groter worden, maar dat moest blijken uit de nog te houden open inschrijving.

\subsection{Open inschrijving}

Op 8 september 2015 heeft RVO een brief gestuurd naar alle beroepsvissers van het IJsselmeer, waarbij deze zich via een open inschrijving konden aanmelden voor deelname. De visser kon kiezen uit een zevental vistuigtypen, het aantal vistuigen per vistuigtype binnen een vooraf opgegeven range, en een aantal regio's; 4 regio's in het IJsselmeer en 4 regio's in het Markermeer. Er is een aantal spelregels voor deelname opgesteld (zie bijlage 4). Door inschrijving bevestigde de inschrijvende visser met deze regels in te stemmen en deze na te zullen leven. De spelregels waren bedoeld om:

- $\quad$ helderheid te geven over de kosten en baten voor de vissers;

- de kwaliteit van het experiment te borgen;

- de naleving van de voorwaarden van de ontheffing van WMR door de geselecteerde vissers te bevorderen;

- de aansprakelijkheid en consequenties van het overtreden van de ontheffingsvoorwaarden vast te leggen.

Vijftien vissers hebben zich ingeschreven via deze open inschrijvingsronde. Het aantal vistuigtypen waarvoor deze belangstelling hadden was 6.

- Aangepaste hokfuik

- Aangepaste schietfuik, zonder ontsnappingsbuis

- Aangepaste schietfuik, met ontsnappingsbuis

- Aangepast staandwant

- $\quad$ Platliggend net (nieuw tuig type voor het IJsselmeer)

- Krabben- of kreeftenkorf (nieuw tuig type voor het IJsselmeer)

De kenmerken van deze vistuigtypen worden vermeld in Tabel 2 en bijbehorende foto's staan in Bijlage 3.

\subsection{Selectie voor deelname}

\subsubsection{Vissers}

Drie van de 15 vissers voldeden niet aan alle voorwaarden die waren gesteld (zie bijlage 4). Van de 12 resterende vissers hebben twee vissers zich in december 2015 teruggetrokken van deelname. Dat betekent dat er 10 vissers overbleven die tot aan het moment van het aanbieden van het contract met WMR wel belangstelling hadden voor deelname. De opzet van het onderzoek werd daarom afgestemd op de deelname van deze 10 vissers. In de volgende paragrafen is dit uitgewerkt voor de vistuigentypen, tijdschema, visserij locaties, en visserij-inspanning.

$\mathrm{Na}$ het aanbieden van het contract van WMR aan elk van deze 10 vissers bleek dat slechts 4 vissers het contract daadwerkelijk ondertekenden. Van de 6 vissers die het contract niet hebben ondertekend, zouden er 3 vissers gaan vissen met verlaagd staandwant, 2 vissers gaan vissen met verlaagd 
staandwant en platliggende netten, en 1 vissers gaan vissen met aangepaste schietfuiken. De reden die deze vissers voor hun aarzeling opgaven was dat ze eerst een uitspraak van de Raad van State over het verminderen van de staande netten op het IJsselmeer wilden afwachten. Toen de uitspraak van de Raad van State bekend was op 26 april 2016, waren ze niet meer gemotiveerd om deel te nemen aan het onderzoek.

$\mathrm{Er}$ is nog een vistuigtype dat niet is getest in dit onderzoek. Dat betreft de schietfuik met een buis. De visser die oorspronkelijk van plan was met dit vistuigtype te gaan vissen in het onderzoek heeft besloten dit toch niet te gaan doen. Hij heeft wel gevist met aangepaste schietfuiken zonder buis maar wel met een groetere maaswijdte (minimaal $70 \mathrm{~mm}$ ) in de laatste kub. De redenen die deze visser hiervoor gaf waren dat het werken met schietfuiken met buizen zeer onpraktisch is en ook onveilig is voor de medewerkers aan boord.

Dit alles had de consequentie dat de opzet voor het onderzoek kort voor de start, terwijl er al toezeggingen waren gedaan aan de 4 vissers die wel hebben getekend, weer moest worden bijgesteld. De definitieve opzet van het onderzoek is beschreven in hoofdstuk 4.

\subsubsection{Vistuigtypen}

De kenmerken van de 6 vistuigtypen die in aanmerking kwamen voor het onderzoek staan vermeld in Tabel 2 en bijbehorende foto's staan in Bijlage 3.

Tabel 2 Vistuigtypen voor het wolhandkrabvisserij onderzoek op het IJ sselmeer

\begin{tabular}{|c|c|c|c|}
\hline Nr. & Status & Vistuig categorie & Kenmerken van het vistuig \\
\hline 1 & Nieuw & Korven & $\begin{array}{l}\text { Vistuig bestaande uit een frame van kunststof of een ander } \\
\text { niet vervormbaar materiaal, met een maximale afmeting van } \\
100 \mathrm{~cm} \text { lengte, } 100 \mathrm{~cm} \text { breedte en } 60 \mathrm{~cm} \text { hoogte, voorzien } \\
\text { van een niet vervormbare omkleding, dan wel een omkleding } \\
\text { van netwerk met maaswijdte van minimaal } 70 \mathrm{~mm} \text {, met een } \\
\text { open inzwemopening met een inkeling van niet vervormbaar } \\
\text { materiaal met een doorsnede van minimaal } 200 \mathrm{~mm} \text {. }\end{array}$ \\
\hline 2 & Aangepast & Hokfuik & $\begin{array}{l}\text { Hokfuik waarvan de achterste kub geheel of deels (ruif) een } \\
\text { maaswijdte heeft van tenminste } 70 \mathrm{~mm} \text {, met een buis met } \\
\text { een diameter van } 200 \mathrm{~mm} \text { en een lengte van maximaal } 400 \\
\mathrm{~mm} \text { die in de laatste kub achterin en horizontaal is geplaatst. }\end{array}$ \\
\hline 3 & Aangepast & Schietfuik & $\begin{array}{l}\text { Schietfuik waarvan de achterste kub geheel of deels (ruif) } \\
\text { een maaswijdte heeft van tenminste } 70 \mathrm{~mm} \text {. }\end{array}$ \\
\hline 4 & Aangepast & Schietfuik & $\begin{array}{l}\text { Schietfuik waarvan de achterste kub geheel of deels (ruif) } \\
\text { een maaswijdte heeft van tenminste } 70 \text { mm, met een buis } \\
\text { met een diameter van } 200 \text { mm en een lengte van maximaal } \\
400 \mathrm{~mm} \text { die in de laatste kub achterin en horizontaal is } \\
\text { geplaatst. }\end{array}$ \\
\hline 5 & Aangepast & Staandwant & $\begin{array}{l}\text { Standaard staandwant (maaswijdte } 101-140 \mathrm{~mm} \text { en } \\
\text { minimale hoogte } 120 \mathrm{~cm} \text { ) ingekort tot maximale hoogte van } \\
30 \mathrm{~cm} \text {. }\end{array}$ \\
\hline 6 & Nieuw & Platliggend net & $\begin{array}{l}\text { Standaard staandwant (maaswijdte } 101-140 \mathrm{~mm} \text { ) materiaal, } \\
\text { platliggend op de bodem door geen drijvers te gebruiken } \\
\text { maar wel loodsim. }\end{array}$ \\
\hline
\end{tabular}

\subsubsection{Tijdschema}

Het doel was het onderzoek zo spoedig mogelijk te starten (richtdatum 1 januari 2016) met een doorlooptijd van 1 jaar, waarbij Tabel 3 wordt gevolgd. Het aantal maanden dat de vissers zouden kunnen vissen was afhankelijk van het vistuigtype. In bepaalde perioden mag met specifieke vistuigen, die zijn gericht op schubvis, niet worden gevist. Van half maart $\mathrm{t} / \mathrm{m}$ april is er een gesloten 
periode in verband met de bescherming van paaiende schubvis. Ook met de andere vistuigtypen wordt niet gevist in de gevoelige periode van schubvis. In mei wordt er niet op schubvis gevist met commercieel staandwant (Tabel 4). Er wordt daarom in dit experiment ook niet in mei op wolhandkrab gevist met verlaagd staandwant en platliggend net. De verschalingsperiode van de wolhandkrab valt in de zomer (juni t/m juli) (Leijzer et al., 2007; Bakker \& Zaalmink, 2012). Er wordt in die periode nauwelijks wolhandkrab gevangen. Er is daarmee gekozen om in juni en juli niet op wolhandkrab te vissen in dit onderzoek. Dat geldt voor alle vistuigtypen

De vistijd voor de nieuwe vistuigen (platliggend net en korven) is het langst, namelijk 8-9 maanden, de overige tuigen mochten alleen korter ingezet worden (Tabel 3 en Tabel 4).

Tabel 3 Tijdschema voor het wolhandkrabvisserij onderzoek

\begin{tabular}{|c|c|c|c|c|c|c|c|c|c|c|c|c|c|}
\hline Nr. & Vistuigtypen & J & $\mathbf{F}$ & $\mathbf{M}$ & $\mathbf{A}$ & $\mathbf{M}$ & J & J & $\mathbf{A}$ & $\mathbf{S}$ & $\mathbf{0}$ & $\mathbf{N}$ & D \\
\hline 1 & Korven & & & & & & & & & & & & \\
\hline 2 & Aangepaste hokfuik & & & & & & & & & & & & \\
\hline 3 & Aangepaste schietfuik & & & & & & & & & & & & \\
\hline 4 & Verlaagd staandwant & & & & & & & & & & & & \\
\hline 5 & Platliggend net & & & & & & & & & & & & \\
\hline
\end{tabular}

Wel visserij met dit vistuigtype in het onderzoek

Optioneel

Geen visserij met dit vistuigtype in het onderzoek

Tabel 4 Tijdstabel voor wolhandkrabvisserij onderzoek en de beroepsvisserij met fuiken en staandwant op het IJ sselmeer

\begin{tabular}{|c|c|c|c|c|c|c|c|c|c|c|c|c|c|}
\hline Vistuigtypen & J & $\mathbf{F}$ & M1 & M2 & $\mathbf{A}$ & M & J & J & $\mathbf{A}$ & $\mathbf{S}$ & $\mathbf{0}$ & $\mathbf{N}$ & D \\
\hline Aangepaste hokfuik & W & W & W & G & G & B & B & B & B & $A$ & $A$ & $A$ & $\mathrm{~B}$ \\
\hline Aangepaste schietfuik & W & W & W & G & G & B & B & B & B & A & W & W & W \\
\hline Verlaagd staandwant & W/ & W/ & $\begin{array}{c}\text { W/ } \\
\text { B }\end{array}$ & G & G & G & G & B & W/ & W/ & W/ & W/ & W/ \\
\hline Platliggend net & W & W & W & G & G & G & G & G & W & W & W & W & W \\
\hline Korven & W & W & W & G & G & W & G & G & W & W & W & W & W \\
\hline
\end{tabular}

\begin{tabular}{|l|l|}
\hline W & Wolhandkrabvisserij met dit vistuigtype voor het onderzoek \\
\hline W/ & $\begin{array}{l}\text { Wolhandkrabvisserij met ingekort staandwant voor het onderzoek en daarnaast bestaande visserij met } \\
\text { niet aangepast staandwant }\end{array}$ \\
\hline B & Bestaande visserij met niet aangepast vistuig, dus niet voor het onderzoek \\
\hline G & Gesloten periode vanwege de paaiperiode van schubvis of de verschalingperiode van wolhandkrab \\
\hline A & Wolhandkrabvisserij met aangepast aalvistuig in de aalgesloten periode, maar niet voor het onderzoek \\
\hline
\end{tabular}

Uit Tabel 3 is af te leiden dat extra tijd per jaar die door het onderzoek maximaal beschikbaar komt voor visserij op wolhandkrab, behoorlijk varieert tussen de 3 geteste vistuigtypen. Deze bedraagt voor de korven, aangepaste schietfuiken en aangepaste hokfuiken respectievelijk $71 \%$, $46 \%$ en $20 \%$.

\subsubsection{Visserijlocaties}

$\mathrm{Na}$ de open inschrijving bleek dat het aantal vissers dat wilde deelnemen in het Markermeer zeer beperkt was en dat op basis daarvan er geen onderzoeksopzet gerealiseerd kon worden. Hierdoor is er besloten het onderzoek uitsluitend uit te voeren in het IJsselmeer.

Het IJsselmeer is opgedeeld in 4 regio's (Bijlage 2) om een beeld te krijgen of de vangsten en bijvangsten verschillen tussen de regio's. Eerder onderzoek (Bult et al. 2007) met fuiken in het IJsselmeer heeft namelijk laten zien dat de vangstverhoudingen worden beïnvloed door factoren als 
jaar en locatie. Hierdoor werd er naar gestreefd in verschillende gebieden jaar rond te bemonsteren. De verdeling van het aantal vistuigen over de regio's staat in Tabel 5.

In het wolhandkrabonderzoek zal de visserij met hokfuiken op vaste plaatsen dichtbij de oever plaatsvinden. Andere visserij moet minimaal 200 meter van deze locaties verwijderd blijven. De visserij met korven, platliggend net en een deel van verlaagd staandwant zal in de buurt van de spuisluis bij Kornwerderzand worden uitgevoerd. Bij de spuisluis van Den Oever zal niet met korven worden gevist, maar wel met platliggend net en verlaagd staandwant. De visserij met schietfuiken en verlaagd staandwant vindt normaliter op open water plaats. De vissers die deelnemen aan het wolhandkrabvisserij onderzoek moeten zich wel houden aan de regio's binnen het IJsselmeer waarvoor ze zich hebben ingeschreven. Met deze indeling wordt bevorderd dat het visserij onderzoek zoveel mogelijk ruimtelijk wordt verspreid over het IJsselmeer. De vissers zijn wel vrij in het kiezen van de vislocaties binnen een regio. De meeste visserij zal plaatsvinden in de regio Noord (langs de Afsluitdijk), gevolgd door West (bij de Noord-Hollandse kust), Oost (Friese kust en Flevoland kust) en Zuidwest (langs de Houtribdijk).

\subsubsection{Visserij-inspanning}

Het aantal vistuigen per vistuigtype is aangegeven in onderstaande Tabel 5. Dit aantal is gebaseerd op de opgave van de vissers in de open inschrijving en bleek niet evenredig verdeeld te zijn over de vistuigtypen. De belangstelling voor twee van de vistuigtypen, namelijk schietfuik met grote maaswijdte en ingekort staandwant, was groter dan voor de andere vistuigtypen. Ook de verdeling over de gebieden was niet evenredig.

Tabel 5 Aantal vistuigen per vistuigtype voor het IJ sselmeer waarmee kon worden gevist in het onderzoek en de bijbehorende visserij-inspanning. Het plan in december 2015.

\begin{tabular}{|c|c|c|c|c|c|c|c|c|c|}
\hline \multirow[t]{2}{*}{$\mathbf{N r}$} & \multirow[t]{2}{*}{ Vistuigtype } & \multirow{2}{*}{\begin{tabular}{|c|} 
Aantal \\
vissers \\
$\#$
\end{tabular}} & \multicolumn{5}{|c|}{ Aantal vistuigen \# } & \multirow{2}{*}{$\begin{array}{c}\begin{array}{l}\text { Visserij- } \\
\text { periode }\end{array} \\
\text { (maanden } \\
\text { per jaar) }\end{array}$} & \multirow{2}{*}{$\begin{array}{c}\begin{array}{c}\text { Visserij- } \\
\text { inspanning }\end{array} \\
\text { (netnachten } \\
\text { per jaar) }\end{array}$} \\
\hline & & & Noord & West & $\begin{array}{l}\text { Zuid- } \\
\text { west }\end{array}$ & Oost & $\begin{array}{c}\text { Totaa } \\
1\end{array}$ & & \\
\hline 1 & Korven & 1 & 30 & 0 & 0 & 0 & 30 & 8.5 & 7799 \\
\hline 2 & $\begin{array}{l}\text { Hokfuik met } \\
\text { grote } \\
\text { maaswijdte en } \\
\text { horizontale buis }\end{array}$ & 1 & 0 & 14 & 20 & 8 & 42 & 2.5 & 3108 \\
\hline 3 & $\begin{array}{l}\text { Schietfuik met } \\
\text { grote } \\
\text { maaswijdte }\end{array}$ & 3 & 262 & 262 & 0 & 0 & 524 & 5.5 & 86984 \\
\hline 4 & $\begin{array}{l}\text { Schietfuik met } \\
\text { grote } \\
\text { maaswijdte en } \\
\text { horizontale buis }\end{array}$ & 1 & 5 & 5 & 0 & 0 & 10 & 5.5 & 1660 \\
\hline 5 & $\begin{array}{l}\text { Staandwant } \\
\text { ingekort tot } \\
\text { max. } 30 \mathrm{~cm} \\
\text { hoogte }\end{array}$ & 5 & 75 & 50 & 0 & 0 & 125 & 7.5 & 16214 \\
\hline 6 & Platliggend net & 2 & 50 & 0 & 0 & 0 & 50 & 7.5 & 6554 \\
\hline
\end{tabular}

\# het aantal vissers en vistuigen is gebaseerd op de opgave van de vissers die in december 2016 aangaven deel te willen nemen aan het onderzoek.

* 3 vissers wilden deelnemen met 2 vistuigtypen. 


\subsubsection{Onderzoek en controle}

Het grootste deel van het project bestaat uit een experimenteel onderzoek ter vaststelling van de (gewenste) vangst van wolhandkrab en (ongewenste) bijvangst van aal en schubvis en de daaruit volgende selectiviteit per vistuigtype. WMR heeft dit onderzoek opgezet en begeleid. De vissers, die zich hiervoor hebben aangemeld, spelen zelf een grote rol spelen in de dataverzameling. Daarnaast begeleiden zoetwatervisserijdeskundigen van ATKB de dataverzameling van de vissers en doen zelf waarnemingen. De keuze van het onderzoeksbureau ATKB is gebaseerd op hun ervaring met deze visserijtechnieken en hun betrokkenheid bij eerder onderzoek naar aanpassingen van vistuigen gericht op reductie van bijvangst van aal en/of schubvis. WMR voert het databeheer uit. De waarnemersreizen hebben tot doel het controleren van het correct uitvoeren van het onderzoek door de vissers en het zelf registreren van de vangst- en bijvangstgegevens voor verdere analyse. Met de waarnemersreizen kan worden geverifieerd of er geen discrepanties zijn tussen de gegevens die de vissers zelf verzamelen en de gegevens die onderzoekers verzamelen. Het is dus een vorm van kwaliteitsborging.

EZ heeft aangegeven dat zij hecht aan een real time controle van het onderzoek ten behoeve van de naleving van de regelgeving. Met het oog hierop heeft WMR voor dit onderzoek een gebruikersovereenkomst voor digitale visvangstregistratie (VRS) afgesloten met Natuurnetwerk. De deelnemende vissers hebben een licentie gekocht bij Natuurnetwerk en kunnen daarmee hun visserijactiviteiten registreren in het VRS. De registratie in VRS is al verplicht voor alle vissers die in de gesloten periode voor het aalherstel met aangepast fuiken op wolhandkrab vissen. Voor onderhavig onderzoek naar de bijvangst van schubvis tijdens/bij wolhandkrabvisserij op het IJsselmeer is door Natuurnetwerk een extra invoer mogelijk gemaakt waarmee de vissers tevens de bijvangst van de aandachtsoorten onder de schubvis kunnen invoeren.

Het beveiligingsbedrijf G4S is ingehuurd voor het uitvoeren van een aantal netcontroles en aanlandcontroles bij vissers die deelnemen aan dit onderzoek.

Er is op 21 december 2015 een startbijeenkomst in Emmeloord georganiseerd met de vissers die op dat moment belangstelling hadden om deel te nemen aan het onderzoek.

In de voorbereidende fase is een protocol voor het wolhandkrabvisserij onderzoek opgesteld. Dit protocol is opgenomen in onderhavig rapport in bijlage 4. 


\section{$4 \quad$ Definitieve opzet van het onderzoek}

Uiteindelijk hebben vier vissers deelgenomen aan deze studie. Één viste met korven bij de sluizen van Kornwerderzand, één met hokfuiken ten noorden van Enkhuizen, langs de Houtribdijk en de kant van Oost Flevoland. Twee visten er met schietfuiken nabij Den Oever (Tabel 6; Figuur 1).

Tabel 6 Deelnemende visbedrijven met type vangsttechniek en aantallen.

\begin{tabular}{|l|l|l|l|}
\hline Bedrijf & Tuig & Aantal & Locaties \\
\hline Visbedrijf van Malsen & Korf & 30 stuks & 1 \\
\hline Visserijmaatschap Blok & Exp1_Hokfuik_mw70_buis_dia200le400 & 42 stuks & 23 \\
\hline VOF Smit & Exp2_Schietfuik_mw70 & 186 stel & 12 \\
\hline Visserijbedrijf A. Hoekman en Zn. B.V. & Exp2_Schietfuik_mw70 & 81 stel & 4 \\
\hline
\end{tabular}

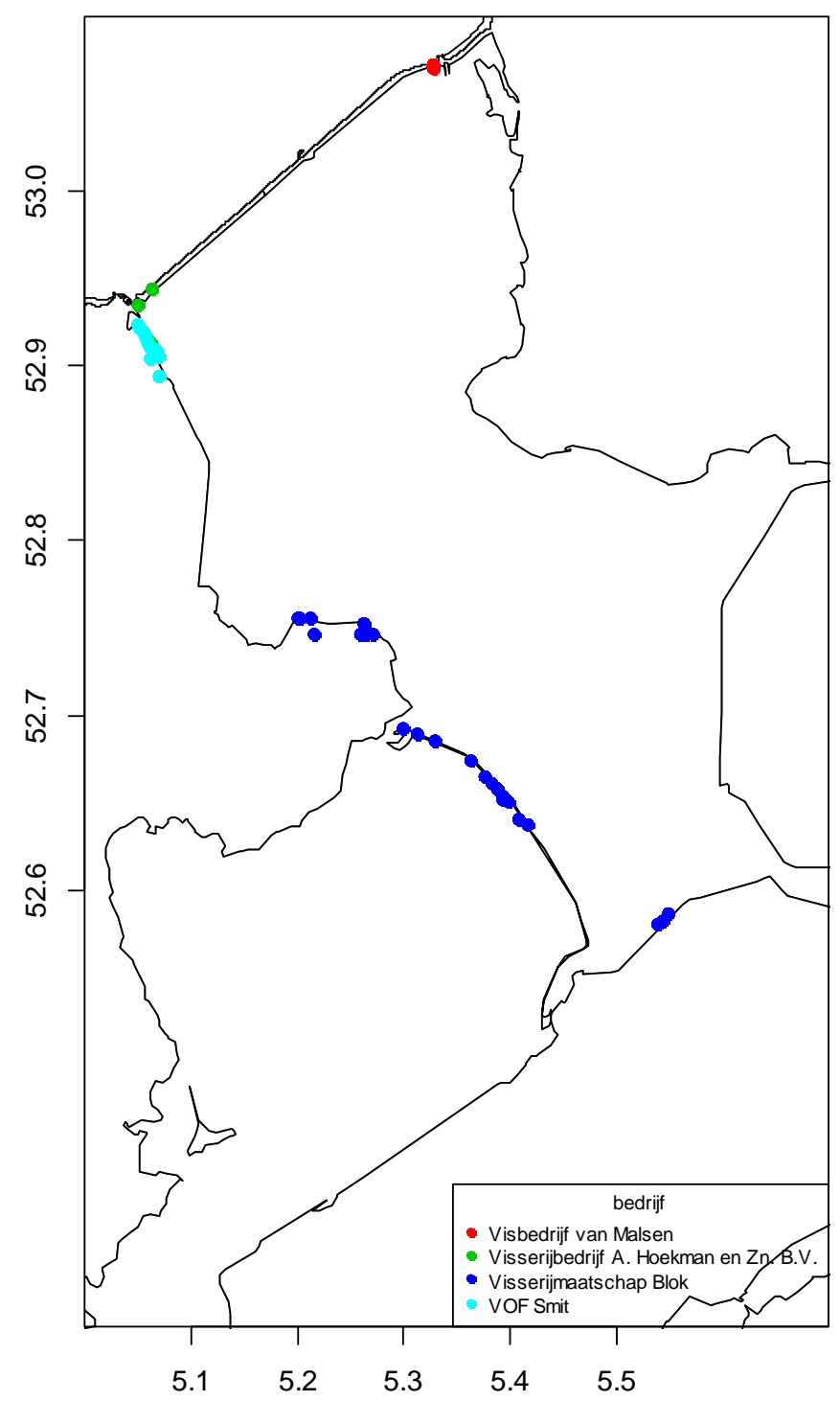

Figuur 1. Locaties wolhandkrab-tuigen per visbedrijf in de periode januari $\mathrm{t} / \mathrm{m}$ medio maart 2016. Voor Visserijmaatschap Blok (EH22) zijn dit vaste locaties. In de resterende periode van dit onderzoek zijn de locaties van Visbedrijf van Malsen identiek, voor VOF Smit (VD94) kan dit enigszins anders zijn, voor Visserijbedrijf A. Hoekman en Zn. B.V (GM29) zijn de locaties soms behoorlijk anders. 
Het tijdschema van het onderzoek is weergegeven in Tabel 7 en Bijlage 6. Er is echter een vertraging van 3 weken opgetreden in het moment van aanbieding van de samenwerkingsovereenkomst door Wageningen Marine Research aan de deelnemende vissers waardoor de deelnemende vissers op zijn vroegst 25 januari 2016 konden beginnen met vissen in het onderzoek. Twee van de 4 vissers zijn later begonnen, maar allemaal hebben ze door gevist tot aan de gesloten periode die medio maart begon (zie Bijlage 6). In de maanden augustus en september is er niet gevist door de korvenvisser, terwijl dat wel mogelijk was volgens de ontheffing. Een van de twee schietfuikenvissers is in het najaar een maand later begonnen met vissen (zie Bijlage 6). De vissers maken blijkbaar de afweging of de verwachte vangst van wolhandkrab wel op zal wegen tegen de inspanning de ze daarvoor zouden moeten doen met de visserijactiviteiten. Hierover is contact geweest tussen WMR en de betreffende vissers, waarbij WMR heeft gewezen op het belang dat het vissen in de gehele toegestane periode heeft voor het onderzoek.

Tabel 7 Tijdschema voor het wolhandkrabvisserij onderzoek

\begin{tabular}{|c|c|c|c|c|c|c|c|c|c|c|c|c|c|}
\hline Nr. & Vistuigtypen & J & $\mathbf{F}$ & $\mathbf{M}$ & $\mathbf{A}$ & M & J & J & $\mathbf{A}$ & $\mathbf{S}$ & $\mathbf{0}$ & $\mathbf{N}$ & D \\
\hline 1 & Korven & & & & & & & & & & & & \\
\hline 2 & Aangepaste hokfuik & & & & & & & & & & & & \\
\hline 3 & Aangepaste schietfuik & & & & & & & & & & & & \\
\hline
\end{tabular}

Wel visserij met dit vistuigtype in het onderzoek

Optioneel

Geen visserij met dit vistuigtype in het onderzoek

Tabel 8 Aantal vistuigen per vistuigtype voor het IJ sselmeer waarmee kan worden gevist in het onderzoek en de bijbehorende maximale visserij-inspanning bij volledige benutting van het aantal vistuigen en de visperiode.

\begin{tabular}{|c|c|c|c|c|c|c|c|c|}
\hline \multirow{2}{*}{ Vistuigtype } & \multirow[t]{2}{*}{ Schip } & \multicolumn{5}{|c|}{ Aantal vistuigen \# } & \multirow{2}{*}{ 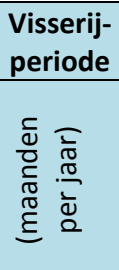 } & \multirow{2}{*}{ 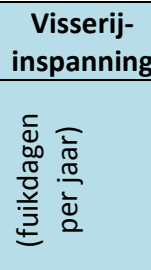 } \\
\hline & & $\begin{array}{l}\text { 만 } \\
\text { 을 }\end{array}$ & 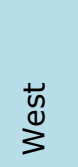 & 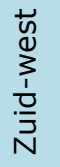 & $\begin{array}{l}\text { ज̆ } \\
\text { Oे }\end{array}$ & $\begin{array}{l}\bar{\pi} \\
\mathbb{N} \\
\stackrel{0}{0} \\
\vdash\end{array}$ & & \\
\hline Korven & WON1 & 30 & 0 & 0 & 0 & 30 & 8.5 & 7770 \\
\hline $\begin{array}{l}\text { Hokfuik met grote maaswijdte en } \\
\text { horizontale buis }\end{array}$ & $\mathrm{EH} 22$ & 0 & 14 & 20 & 8 & 42 & 2.5 & 3150 \\
\hline Schietfuik met grote maaswijdte & VD94 & 100 & 100 & 0 & 0 & 200 & 5.5 & 33400 \\
\hline Schietfuik met grote maaswijdte & GM29 & 62 & 63 & 0 & 0 & 125 & 5.5 & 20875 \\
\hline
\end{tabular}

\section{$4.1 \quad$ Voorbereiding}

De gebruikte tuigen werden door de vissers zelf geprepareerd en moesten voldoen aan de beschrijving in de Tabel 2. Eventueel nieuwe tuigen moesten worden aangeschaft of oude tuigen moesten worden aangepast om te voldoen aan de beschrijving. De tuigen moesten nagemeten worden en de specifieke details moesten worden gerapporteerd. Vervolgens moesten de tuigen gemerkt/genummerd worden, zodat het bekend is welk van de tuigen ingezet is. Verdere voorbereiding verschilt niet van de normale visserij. 


\subsection{Plaatsen van tuigen}

Het plaatsen van de tuigen gebeurde volgens eigen inzicht van de visser en volgens de normale gang van zaken in de visserij. Het plaatsen vond plaats in het vooraf afgesproken gebied. Binnen dit gebied was de visser vrij om naar eigen inzicht de locaties te kiezen, rekening houdend met bestaande regelgeving en afstemming met eventuele andere vissers in het onderzoek. De exacte locatie werd op het moment van uitzetten in het Digitale Vangst Registratiesysteem (VRS) van bureau Natuurnetwerk geregistreerd op basis van de gps coördinaten.

Enkele tuigconfiguraties werden als individuele objecten geplaatst. Voor deze tuigen moesten de gegevens per individueel tuig geregistreerd worden in het digitale Visvangstregistratiesysteem (VRS). Dit gebeurde voor de korven, aangezien deze individueel verschillen.

Bij voorkeur werden alle tuigen individueel geregistreerd in het VRS. Na overleg is er besloten hiervan af te stappen omdat het veel te veel werk voor de vissers was. Daarom zijn de hokfuiken in de meeste gevallen per stel en de schietfuiken per regel of stal geplaatst en geregistreerd. In dit geval moesten alle tuigen in de groep van dezelfde configuratie zijn en het aantal tuigen in de regel of stal moest gerapporteerd worden. Ook bij schietfuiken in een stel moesten beide schietfuiken van dezelfde configuratie zijn en moesten er twee tuigen gerapporteerd worden.

\subsection{Lichten van tuigen}

Voorafgaande aan de dag van lichten van de vistuigen dienden de vissers dit voor 18:00 aan te geven in het registratiesysteem (datum, tijd, vertrek locatie en aanland locatie). Bij het lichten werd er in de VRS aangegeven dat het tuig werd gelicht, waardoor de tijd werd geregistreerd.

Vervolgens moesten alle krabben en vissen uit de kub verwijderd worden en per tuig of groep tuigen apart gehouden worden (niet in de overlevingsbak). Het ging hierbij uitsluitend om de vissen in de kub, dus niet de vissen in de kelen of andere delen van het net. De vangst werd niet in de overlevingsbak gestort omdat dan het doormeten en registreren van alle vangst niet meer mogelijk is.

Vervolgens moesten de volgende soorten onderscheiden worden:

1. Wolhandkrab (uitsluitend gewicht)

2. Rode aal

3. Schier aal

4. Baars $<22 \mathrm{~cm}$

5. Baars $>22 \mathrm{~cm}$

6. Blankvoorn

7. Snoekbaars $<42 \mathrm{~cm}$

8. Snoekbaars $>42 \mathrm{~cm}$

9. Bot

10. Brasem

Van deze 10 groepen moesten de aantallen vis per categorie geteld worden en vervolgens moest het gewicht bepaald worden. Bij grote aantallen (>50 individuen) was het voldoende om uitsluitend het gewicht te rapporteren. Het bepalen van het gewicht moest zo nauwkeurig mogelijk gebeuren (gram) met behulp van een weegschaal of unster. Deze gegevens moesten per tuig of groep tuigen geregistreerd worden in het VRS.

Daarna moest alle vis worden teruggezet. Dit betekent dat ook maatse vis teruggezet diende te worden.

Daarnaast moesten bijvangsten van vogels geregistreerd worden, waarbij de volgende vogelsoorten onderscheiden moesten worden:

1. Aalscholver 

2. Fuut
3. Grote zaagbek
4. Middelste zaagbek
5. Nonnetje
6. Tafeleend
7. Kuifeend
8. Toppereend
9. Brilduiker
10. Meerkoet
11. Andere vogelsoort (vermeld de naam van de soort indien bekend)

\subsection{Invoeren van gegevens}

\subsubsection{Digitale Vangst Registratie}

Registratie van de vangst vond plaats via het Digitale Visvangstregistratiesysteem (VRS) ontwikkeld door bureau Natuurnetwerk. Voor het gebruik van VRS dienden de vissers een licentieovereenkomst te sluiten met Natuurnetwerk. Om VRS te kunnen gebruiken is een tablet of smartphone noodzakelijk, bij voorkeur met GPS. De mobiele website is te vinden op http://mobiel.visvangstregistratie.nl. De login gegevens werden verstrekt door Natuurnetwerk en golden zowel voor de mobiele site als de gewone site (http://www.visvangstregistratie. $\mathrm{nl}$ ).

- Via het VRS dienden vissers, die mee deden aan dit onderzoek, de locaties waar zij hun tuigen gingen plaatsen in te voeren. Deze locaties werden vastgelegd in een database. Deze database is toegankelijk voor de bij het project betrokken toezichthouders. Ook de NVWA en de Visserijkundig Ambtenaren van EZ hebben toegang tot het VRS.

- Via het VRS dienden de vissers voorafgaande aan de visserij te melden:

- De datum waarop zij willen gaan vissen

- Vertreklocatie en vertrektijd

- Aanlandlocatie

Op basis van deze gegevens kon een planning gemaakt worden van de op een bepaalde dag te controleren visser(s) en vanuit de kant van het onderzoek om een waarnemer mee te sturen voor aanvullende metingen.

- $\quad$ Op de dag zelf dat de visser wil gaan vissen dienden zij op het tijdstip van vertrek een vertrekmelding te doen.

- Als de visser eenmaal gevorderd is met de visserij en zodoende zicht had op het tijdstip waarop hij naar schatting op de aanlandplaats kon arriveren, diende dit tijdstip door de visser te worden ingevoerd in het VRS.

Op basis hiervan kon een planning gemaakt worden voor uit te voeren aanlandcontroles.

- Tenslotte bood het VRS de mogelijkheid om de resultaten van het onderzoek vast te leggen, zoals in Tabel 9.

Tabel 9 Type gegevens dat dient te worden ingevoerd in het digitale Visvangstregistratiesysteem (VRS) ontwikkeld door bureau Natuurnetwerk.

\begin{tabular}{|l|l|}
\hline Variabelen & Betekenis \\
\hline Jaar & jaar lichten \\
\hline Maand & maand lichten \\
\hline Dag & dag lichten \\
\hline Tijd & tijd (AMS) lichten \\
\hline Sta-duur (uur) & Sta-duur van de fuik in uren \\
\hline Vistuig & gebruikt vistuig (zie Tabel 2) \\
\hline Fuiknummer & fuiknummer (of ander merknummer) \\
\hline Maaswijdte (mm) & kleinste maaswijdte in het vistuig \\
\hline Aantal vistuigen uitgezocht & aantal vistuigen dat in dit monster is samengevoegd \\
\hline Aantal & per soortsgroep het aantal gevangen individuen \\
\hline Gewicht & per soortsgroep het totale gewicht. \\
\hline
\end{tabular}




\subsubsection{Papieren logboek}

Er werd ook verzocht om in een eigen logboek aanvullende gegevens te registreren over:

- weersomstandigheden

- spui-omstandigheden waarbij de tuigen hebben gestaan

- schade aan of begroeiing op de tuigen

- andere bijvangsten.

\subsection{Aanvullende methoden voor Waarnemers}

De waarnemers konden willekeurig opstappen bij een van de deelnemende vissers op basis van de gegevens in het VRS. Er werd naar gestreefd dat iedere visser één tot enkele keren in de gehele periode bezocht werd. Daarnaast zijn waarnemers extra meegaan omdat vissers problemen hadden met de registratie in VRS en de gegevens in VRS vraagtekens opriepen over de uitgevoerde werkzaamheden.

Tijdens de reizen met de waarnemers, hebben de vissers op de hierboven geschreven manier de vangsten geregistreerd. De waarnemers registreren de zelfde gegevens. Daarnaast bepalen de waarnemers de lengtesamenstelling van de vangst. Hiervoor meten zij per tuig (of regel/stal) per soort de individuen. Meten gebeurt voor totale lengte van de vis in $\mathrm{cm}$ afgerond naar beneden en voor Wolhandkrab wordt de breedte van het rugschild gemeten in $\mathrm{mm}$.

Eventueel kan er een subsample door gemeten worden (minimaal 50 individuen). Een subsample kan visueel bepaald worden door de vangst in gelijke delen te splitsen of kan bepaald worden op basis van gewicht. Als het op basis van gewicht gebeurt, wordt het gewicht van het totale sample bepaald en vervolgens het gewicht van het doorgemeten sample.

Het invoeren van de gegevens is gebeurd door de waarnemers in het IMARES programma Billie8. De ingevoerde basis gegevens staan in Tabel 10. Daarnaast zijn de lengte metingen per soort ingevoerd. De gegevens zijn bij voorkeur aan boord ingevoerd. Na het einde van de survey zijn de Billie bestanden aangeboden aan de WMR database beheerder, vervolgens zijn deze routinematig gecontroleerd en in de FRISBE database gezet.

Bij de wolhandkrab is voor de omrekening van de breedte van het rugschild naar gewicht van het individu gebruik gemaakt van de rugschildbreedte-gewicht relatie die is gepubliceerd door Czerniejewski (2010).

\subsection{Kwaliteitsborging}

De kwaliteit van de data is afhankelijk van de door de vissers en waarnemers aangeleverde gegevens. De vissers krijgen een duidelijke uitleg en kunnen te allen tijde met vragen bij WMR terecht.

Daarnaast worden de gegevens van de vissers tussentijds gecontroleerd zodat er contact kan zijn over eventuele onduidelijkheden of uitschieters. De waarnemers zijn ervaren met deze werkzaamheden in het veld, zowel de WMR als extern ingehuurde waarnemers. De Billie files worden automatisch gecheckt op allerlei mogelijke fouten (posities, visduur, max en minimale lengtes etc.) alvorens ze de database ingaan. 
Tabel 10 Overzicht registratie gegevens visbemonstering door de waarnemers in het IMARES programma Billie8.

\begin{tabular}{|c|c|}
\hline Waarneming & Omschrijving \\
\hline Programme & SELCWK \\
\hline Version & 1.0 \\
\hline \multicolumn{2}{|l|}{ Vessel } \\
\hline Country & Default NED \\
\hline Time Accuracy & Minuten (60) \\
\hline Station ID & Tuig/fuiknummer \\
\hline Date & [yyyymmdd] \\
\hline Time & tijd van lichten (hhmm) \\
\hline Sample ID & Lijst met nummers gegenereerd door de IMARES database beheerder \\
\hline Haul duration & in negatieve minuten (gebruik "Click me" voor het berekenen van de staduur) \\
\hline Missing Taxon & $\begin{array}{l}\text { Default }=\mathrm{C} \\
\text { c: missend record in Class tabel betekent dat een soort niet gevangen is. } \\
\mathrm{i}: \text { missend record in tabel Class tabel betekent dat niet alle soorten bekeken zijn. }\end{array}$ \\
\hline Haul Validity & Default $\sqrt{ }=$ trek is geldig, als trek ongeldig is dan vinkje weghalen \\
\hline Area code & Hoknummer + Subcode \\
\hline Latitude shoot & uitzetpositie \\
\hline Longitude shoot & uitzetpositie \\
\hline \multicolumn{2}{|l|}{ Latitude haul } \\
\hline \multicolumn{2}{|l|}{ Longitude haul } \\
\hline Units Total Catch & Schatting van de totale vangst \\
\hline Crew members & NB: voer in elk geval in wie invoerder, reisleider en meter was! \\
\hline Gear type & $\begin{array}{l}\text { Tuigcode: } \\
\text { Schietfuik } \\
\text { Hokfuik } \\
\text { Staandwant } \\
\text { Korf } \\
\text { Kooi }\end{array}$ \\
\hline Gear sub type. & $\begin{array}{l}\text { Sub type van het gekozen tuig (Definitieve codes moeten nog worden bepaald) } \\
\text { Geheel ruif met buis } \\
\text { Deels ruif met buis } \\
\text { etc }\end{array}$ \\
\hline Gear count & Aantal tuigen $(1$, of aantal in regel of stal) \\
\hline Meshsize & $\mathrm{mm}$ \\
\hline Water Depth & water diepte (meters) \\
\hline Comment & optioneel: Eventueel commentaar op de eigenschappen \\
\hline
\end{tabular}

\subsection{Controle op naleving}

Er zijn door G4S een aantal onaangekondigde controles uitgevoerd bij de 4 vissers die deelnamen aan het onderzoek wolhandkrabvisserij IJsselmeer. Bij elk van de vissers is minimaal een netcontrole en een aanlandcontrole gedaan. G4S heeft rapportages van deze controles opgesteld en opgestuurd naar WMR. Voor deze rapportage is gebruik gemaakt van een formulier waarin de vragen staan die relevant zijn om na te lopen bij een controle (zie bijlage 5). Er zijn geen onregelmatigheden geconstateerd. 


\section{Resultaten}

In dit hoofdstuk worden de resultaten uit het onderzoek gepresenteerd. Hierbij worden achtereenvolgens behandeld de details van de vistuigtypen en visserijlocaties, visserijinspanning, vangst van wolhandkrab, bijvangst van vis, soortensamenstelling van vis, verhouding van bijvangst t.o.v. vangst van wolhandkrab, bijvangst van vogels. Dit gebeurt steeds afzonderlijk voor eerst de resultaten die zijn gebaseerd op gegevens die de vissers in VRS hebben geregistreerd en daarna die door de waarnemers zijn gemeten en in de Wageningen Marine Research database zijn ingevoerd. Vervolgens wordt er, voor deze resultaten waarvoor dat mogelijk is, een vergelijking gemaakt tussen beide registratiemethoden.

\section{$5.1 \quad$ Geteste vistuigtypen}

In de volgende paragrafen wordt per visserijbedrijf nader ingegaan op de registratie van de gegevens door de 4 deelnemende vissers in het digitale visvangstregistratiesysteem (VRS) en de vangst- en bijvangstgegevens daaruit, alsmede de waarnemingen van de waarnemers.

\subsubsection{Visbedrijf van Malsen (WON1) met korven}

Visbedrijf van Malsen plaatste in één keer op nagenoeg dezelfde locatie 30 korven aan 1 lijn in het noorden van het IJsselmeer nabij de spuisluizen van Kornwerderzand (Figuur 1). De korven werden ook weer in 1 keer allemaal opgehaald en vervolgens opnieuw uitgezet. Er is door Van Malsen een grote variatie aan vorm, kleur, maaswijdte en ruifmaaswijdte toegepast. Een specificatie daarvan is te vinden in bijlage 7 , met daarbij tevens een aanduiding van de waterdiepte van de geplaatste korven.

In het VRS systeem zijn de korven genummerd van 1 tot 30, de verdere beschrijving is niet opgenomen. De data in het VRS systeem laten echter niet zien dat alle 30 korven zijn geplaatst. Maar een deel van de korven is goed geregistreerd in het systeem, ditzelfde gebeurt tijdens het ophalen en opnieuw uitzetten van de korven. Per uitzet en ophaal datum is een verschillend aantal korven geregistreerd. Dat betekent dat voor verder analyse per ophaaldatum de (bij)vangst wordt samengevoegd voor alle 30 korven.

De vangsten in de korven zijn klein en maar een beperkt aantal korven bevatte wolhandkrab. Van Malsen gaf aan dat de locatie voor de vangst van wolhandkrab niet optimaal was en dat hij normaliter de korven tijdens de pilot op een iets andere locatie had geplaatst om meer wolhandkrab te vangen. Hij heeft dat in overleg met Wageningen Marine Research niet gedaan om de analyse van het seizoenseffect op vangst en bijvangst niet te bemoeilijken. De vislocatie was dichtbij de spuisluizen van Kornwerderzand. Het spuien heeft volgens deze visser een groot effect op de bijvangst want door het spuien zullen bijna alle bijgevangen vissen uit de korven spoelen. Dat betekent dat het moment van het lichten van de korven van grote invloed kan zijn op de hoeveelheid bijvangst. Het aantal korven met wolhandkrab in VRS kwam niet altijd overeenkomt met de registratie door de waarnemers. Dit betekent dat het lastig is de gegevens uit het VRS terug te brengen naar individuele korf. Ondanks de kleine aantallen vis en wolhandkrab zit er toch enig verschil tussen de aantallen ingevoerd in VRS en de aantallen gemeten door de waarnemers. 


\subsubsection{Visserijmaatschap Blok(EH22) met aangepaste hokfuiken}

Visserijmaatschap Blok heeft op 23 locaties hokfuiken geplaatst. In totaal zijn er 20 paren en 4 individuele fuiken geplaatst, in totaal dus 42. Dit waren hokfuiken waarvan de achterste kub geheel of deels (ruif) een maaswijdte had van tenminste $70 \mathrm{~mm}$, met een buis met een diameter van $200 \mathrm{~mm}$ en een lengte van maximaal $400 \mathrm{~mm}$ die in de laatste kub achterin en horizontaal is geplaatst. de lengte van de buis is maximaal $40 \mathrm{~cm}$ om te voorkomen dat zich een te lang stuk buis binnen in de fuik bevindt welke daarmee de ontsnappingskans van de bijgevangen vis verkleint. Er steekt even veel buislengte naar binnen en naar buiten, om daarmee voldoende stabiliteit van de buis te bereiken (mondelinge mededeling R. Blok).

De vangsten in het VRS zijn bijna allemaal terug te brengen op locatie, dus 1 of 2 hokfuiken te samen. De gegevens zijn hier echter gepresenteerd per ophaaldag. Per ophaaldag verschilt de sta-duur en het aantal geleegde fuiken. Tussen de (bij)vangst van de fuiken opgehaald op dezelfde dag zit daardoor veel variatie.

Er zijn driemaal waarnemers met Blok mee geweest. De eerste keer betrof dat waarnemers van Wageningen Marine Research en daarna tweemaal waarnemers van ATKB. Op deze manier zijn in totaal 25 locaties bemonsterd door waarnemers.

\subsubsection{VOF Smit (VD94) met aangepaste schietfuiken}

VOF Smit is gaan vissen met schietfuiken waarvan de achterste kub geheel een maaswijdte heeft van tenminste $70 \mathrm{~mm}$. Uit de data die VOF Smit in het VRS heeft ingevoerd in VRS is niet altijd duidelijk wat de vislocaties zijn geweest. Er worden twee referenties gegeven namelijk Noord en west, maar met verschillende geografische posities en het aantal tuigen per positie varieert. Doordat alles te samen is gerapporteerd is het niet mogelijk om de vangsten terug te brengen naar tuig of locatie. Voor de weergave van de resultaten van de vangst en bijvangst is er in dit rapport daarom voor gekozen die per visreis voor alle fuiken samen te vermelden.

\subsubsection{Visserijbedrijf A. Hoekman en Zn. B.V. (GM29) met aangepaste schietfuiken}

Visserijbedrijf A. Hoekman en Zn. B.V. heeft gevist met schietfuiken waarvan de achterste kub geheel of deels (ruif) een maaswijdte heeft van tenminste $70 \mathrm{~mm}$. De verhouding tussen die 2 soorten aanpassingen is ongeveer gelijk (persoonlijke mededeling S. Hoekman). De schietfuiken zijn geplaatst in verschillende groepen (ook wel treinen, lagen, stellen genoemd) met een wisselend aantal schietfuiken.

De vangsten voor een dag zijn echter voor alle opgehaalde tuigen te samen gerapporteerd in het VRS. Het is dus niet mogelijk om de vangst op individueel stel, laat staan op individuele schietfuik terug te brengen. Doordat soms een stel fuiken opnieuw is uitgezet en de vangst vervolgens samen met het een ander stel is gerapporteerd, is voor de vangst op sommige ophaaldagen geen exacte sta-duur te bepalen. De visserijinspanning is daarom niet exacte te kwantificeren. In de analyse van de vangst en bijvangst resultaten van deze visser werken we daarom alleen met de maximale visserij-inspanning rapportage, waardoor de (bij)vangst per vistuigdag ook niet exact is te geven en een minimale (bij)vangst per vistuigdag is.

\subsection{Vangstregistratie door vissers}

\subsubsection{Visserij inspanning}

Het tijdschema voor de visserij in het onderzoek, zoals maximaal mogelijk was en wanneer er daadwerkelijk is gevist, is te vinden in bijlage 6. Daaruit is af te leiden dat de EH22 $100 \%$ van de beschikbare tijd heeft gevist met de aangepaste hokfuiken. De WON1 heeft $67 \%$ van de tijd gevist met de korven en de VFD94 en GM29 hebben respectievelijk 75\% en 46\% van de tijd gevist met aangepaste schietfuiken. Een overzicht van de dagen, waarop de vistuigen werden gehaald en de 
vangst en bijvangst door de vissers werd geregistreerd, staat in Tabel 11 . Op 16 van deze 36 visreizen zijn er waarnemers mee aan boord gegaan die zelf metingen hebben verricht.

Tabel 11 Data van de van de visreizen van de vissers, waarbij de vistuigen zijn gehaald en vangst is geregistreerd. Op de visreizendata die vet zijn weergegeven, zijn waarnemers mee geweest.

\begin{tabular}{|c|c|c|c|c|}
\hline $\mathbf{N r}$ & Korf & Hokfuik & Schietfuik & Schietfuik \\
\hline & WON-1 & $\mathrm{EH}-22$ & VD-94 & GM-29 \\
\hline & Van Malsen & Blok & Smit & Hoekman \\
\hline 1 & $2 / 10 / 2016$ & $2 / 4 / 2016$ & $2 / 26 / 2016 \#$ & $3 / 7 / 2016$ \\
\hline 2 & $2 / 29 / 2016$ & $2 / 5 / 2016$ & $3 / 14 / 2016$ & $3 / 14 / 2016$ \\
\hline 3 & $3 / 14 / 2016$ & $2 / 12 / 2016$ & $10 / 17 / 2016$ & $11 / 10 / 2016$ \\
\hline 4 & $5 / 16 / 2016$ & $2 / 18 / 2016$ & $11 / 2 / 2016$ & $12 / 6 / 2016$ \\
\hline 5 & $5 / 23 / 2016$ & $2 / 25 / 2016$ & $11 / 16 / 2016$ & $12 / 21 / 2016$ \\
\hline 6 & $5 / 31 / 2016$ & $3 / 1 / 2016$ & $11 / 29 / 2016$ & $12 / 22 / 2016$ \\
\hline 7 & $10 / 20 / 2016$ & $3 / 8 / 2016$ & $12 / 14 / 2016$ & \\
\hline 8 & $11 / 10 / 2016$ & $3 / 9 / 2016$ & & \\
\hline 9 & $11 / 30 / 2016$ & $3 / 10 / 2016$ & & \\
\hline 10 & $12 / 19 / 2016$ & $3 / 11 / 2016$ & & \\
\hline 11 & $12 / 30 / 2016$ & $3 / 14 / 2016$ & & \\
\hline 12 & & $3 / 15 / 2016$ & & \\
\hline
\end{tabular}

\# Geen invoer van de gegevens van deze visreis in VRS wegens weigering van het systeem. Wel registratie door de waarnemer

Tabel 12 Visserij inspanning door de vissers in het onderzoek

\begin{tabular}{|l|c|c|c|c|}
\hline & Korf WON1 & Hokfuik EH22 & Schietfuik VD94 & Schietfuik GM29 \\
\hline Aantal vistuigen & 30 & 42 & 186 & max.81\# \\
\hline Aantal visdagen per vistuig & 157 & 45.5 & 106 & max.66 \# \\
\hline $\begin{array}{l}\text { Visserij inspanning } \\
\text { (aantal vistuigdagen) }\end{array}$ & 4710 & 1910 & 19716 & max. 5346 \# \\
\hline
\end{tabular}

\# er zijn geen exacte waarden te geven, daarom worden er maximale waarden vermeld.

\subsubsection{Vangst van wolhandkrab op basis van VRS}

De vangst van wolhandkrab is weergegeven in gewicht voor elke visreis tijdens het onderzoek (Figuur 2, alsmede op basis van gewicht en per visserij-inspanning over de gehele onderzoeksperiode ( Tabel 13). De vangst van wolhandkrab, zowel absoluut als per visserij-inspanning, is het grootste bij hokfuiken en het kleinste bij de korven. 


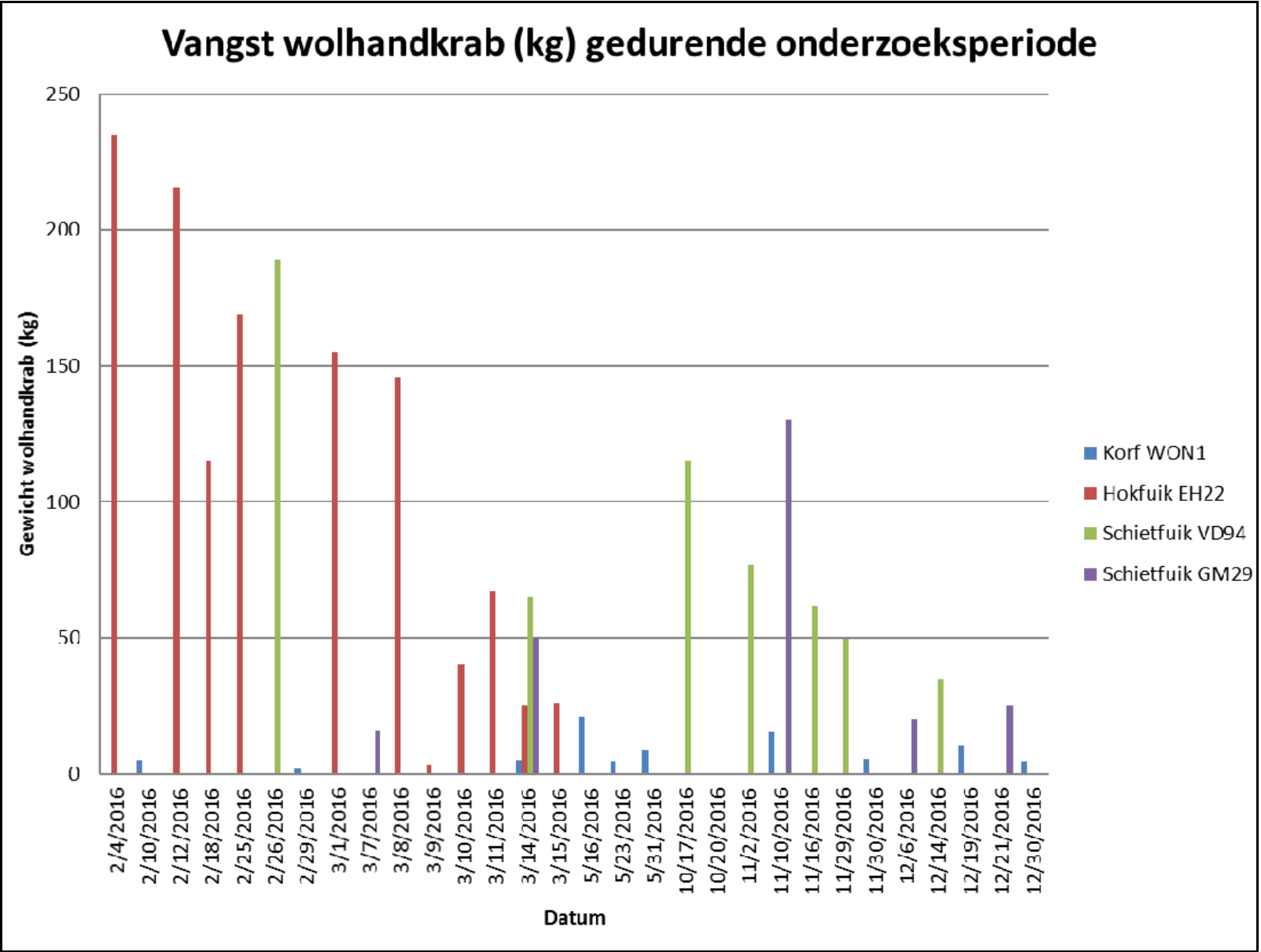

Figuur 2 Vangst van wolhandkrab $(\mathrm{kg})$ gedurende het onderzoek geregistreerd door de vissers in VRS.

Tabel 13 Totale vangst van wolhandkrab (WHK) in het onderzoek geregistreerd door de vissers in VRS.

\begin{tabular}{|l|l|r|r|r|}
\hline Vistuigtype & Schip & Gewicht $(\mathrm{kg})$ & \multicolumn{1}{c|}{ Aantal vistuigdagen } & WHK gewicht (gram)/vistuigdag \\
\hline Korf & WON1 & 81.3 & 4710 & 17 \\
\hline Hokfuik & EH22 & 1302.5 & 1910 & 682 \\
\hline Schietfuik & VD94 & 592.0 & 19716 & 30 \\
\hline Schietfuik & GM29 & 241.0 & $5346 \#$ & 45 \\
\hline
\end{tabular}

\# alleen de maximum waarde kan worden geschat

\subsubsection{Bijvangst van vis op basis van VRS}

De bijvangst als gewicht per vissoort op verschillende momenten in het onderzoek wordt getoond in Figuur 3 en op basis van de visserij-inspanning in Tabel 14.

In de korven werden geen grote baars, snoekbaars en schieraal bijgevangen. In de hokfuiken en schietfuiken werd een veel groter gewicht aan kleine dan aan grote baars en snoekbaars bijgevangen. In de verdere berekeningen wordt de categorie van kleine baars en kleine snoekbaars daarom gecombineerd met de categorie van respectievelijk grote baars en grote snoekbaars. 


\section{Korf WON1}
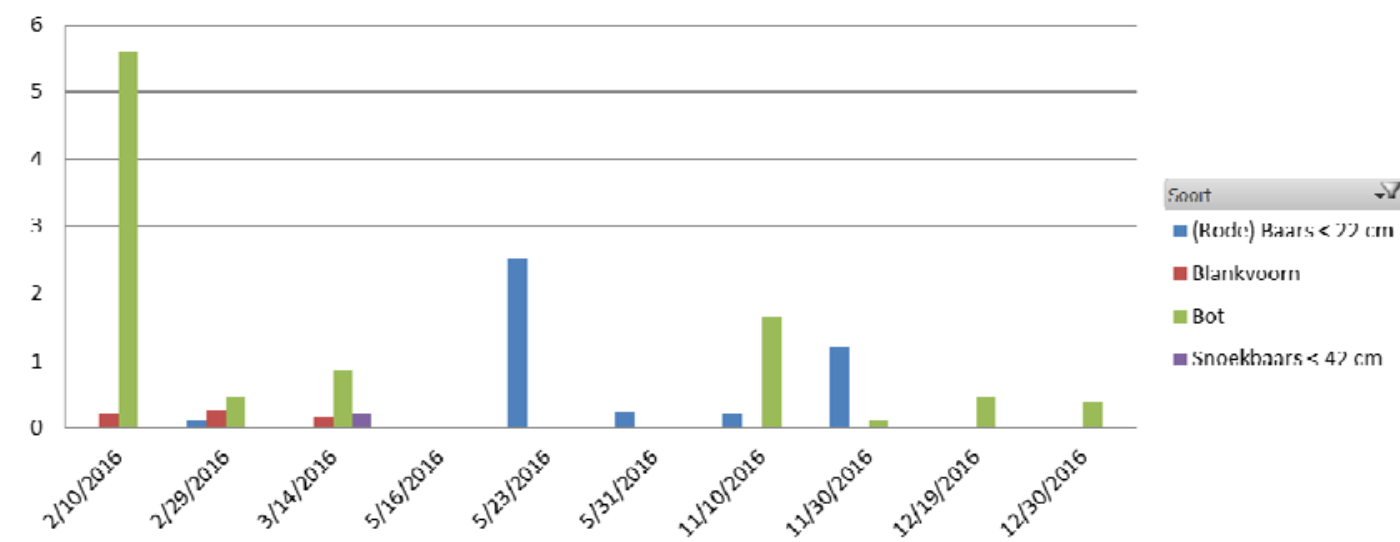

an Blarıvoorn

not

= Snnekhanrs $<4$ ) cm

\section{Hokfuik EH22}
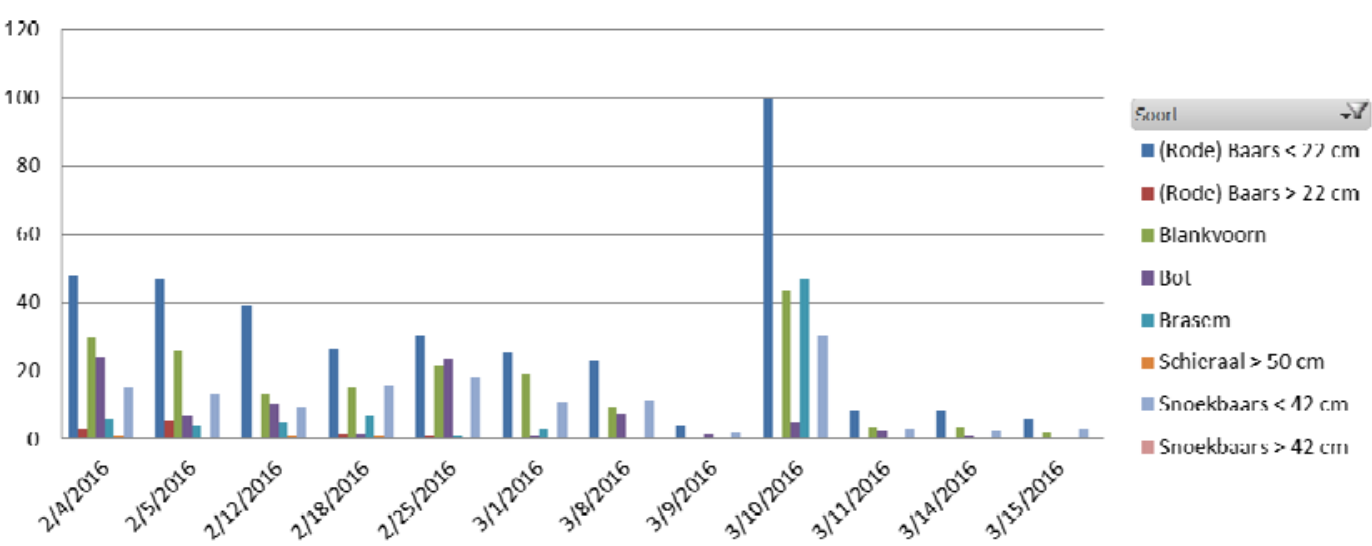

E (Kode) haars «ग cm

a (Rode) Baars $>22 \mathrm{~cm}$

m Blankvoorn

- Bol

n Rrass.m

= $S$ chicraal $>50 \mathrm{~cm}$

Snoekbaars $<12 \mathrm{~cm}$

- Snuekbaar $s>42 \mathrm{~cm}$

\section{Schietfuik VD94}
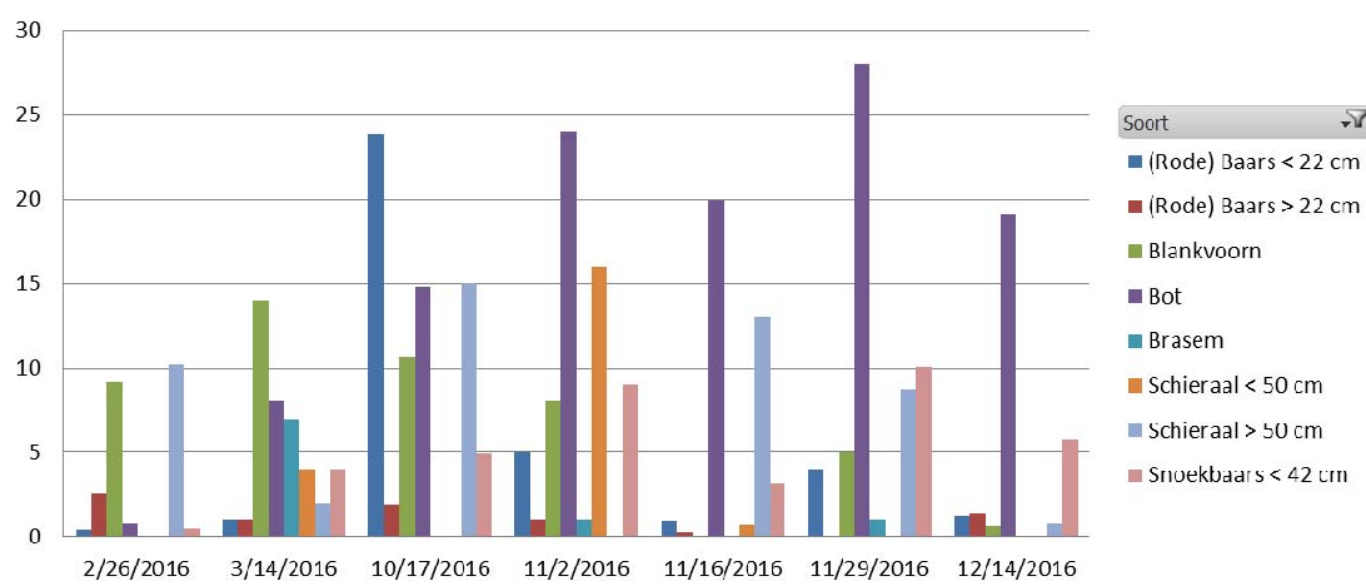

- (Rode) Baars $<22 \mathrm{~cm}$

- (Rode) Baars $>22 \mathrm{~cm}$

- Blankvoorn

a Bot

Brasem

n Schieraal $<50 \mathrm{~cm}$

- schieraal > $50 \mathrm{~cm}$

n Snvekbaars $<42 \mathrm{im}$

\section{Schietfuik GM29}

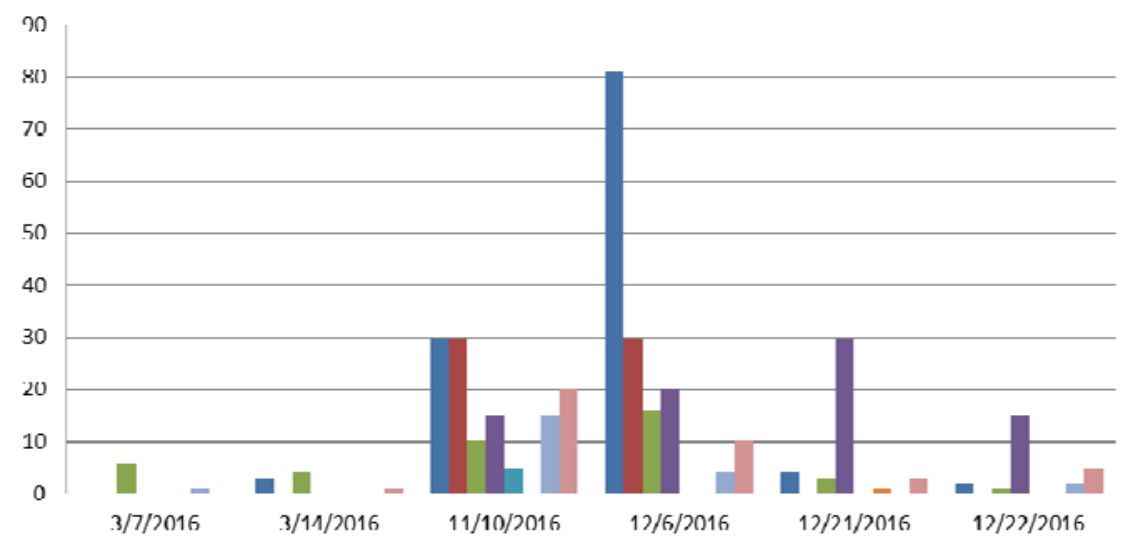

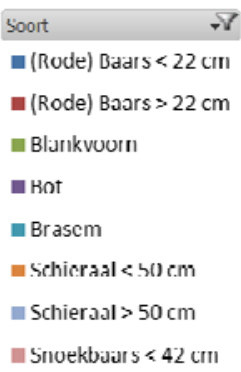

Figuur 3 Bijvangst van vis (gewicht in $\mathrm{kg}$ ) in de verschillende vistuigen geregistreerd door de vissers in 
VRS.

Tabel 14 Totale bijvangst van vis (gewicht in $\mathrm{kg}$ ) in het onderzoek geregistreerd door de vissers in VRS.

\begin{tabular}{|l|c|c|c|c|}
\hline Soort & Korf WON1 & Hokfuik EH22 & Schietfuik VD94 & Schietfuik GM29 \\
\hline (Rode) Baars < 22 cm & 4.3 & 366 & 36.5 & 120 \\
\hline (Rode) Baars > 22 cm & & 10.6 & 8.2 & 60.0 \\
\hline Snoekbaars < 42 cm & 0.22 & 135 & 37.0 & 39.0 \\
\hline Snoekbaars > 42 cm & & 0.50 & & 40.0 \\
\hline Blankvoorn & 0.63 & 187 & 47.4 & 5.0 \\
\hline Brasem & & 73.8 & 9.0 & 1.0 \\
\hline Schieraal < 50 cm & & & 20.7 & 22.0 \\
\hline Schieraal > 50 cm & & 3.0 & 49.8 & 80.0 \\
\hline Bot & 9.5 & 85.6 & 115 & \\
\hline
\end{tabular}

De gegevens in Tabel 14 zijn omgerekend naar de bijvangst per vissoort op eenheid van visserijinspanning. Het resultaat staat in Tabel 15.

Tabel 15 Totale bijvangst van vis in gewicht (gram) per soort per vistuig in een vistijd van 100 dagen. Gebaseerd op gegevens geregistreerd door vissers in VRS.

\begin{tabular}{|l|c|c|c|c|}
\hline Soort & Korf WON1 & Hokfuik EH22 & Schietfuik VD94 & Schietfuik GM29 \\
\hline Baars & 92 & 19720 & 227 & 3367 \\
\hline Snoekbaars & 5 & 7110 & 190 & 730 \\
\hline Blankvoorn & 13 & 9793 & 240 & 748 \\
\hline Brasem & 0 & 3864 & 46 & 94 \\
\hline Schieraal & 0 & 157 & 357 & 430 \\
\hline Bot & 202 & 4482 & 581 & 1496 \\
\hline
\end{tabular}

Baars is de commerciële vissoort die het meest wordt bijgevangen, gevolgd door blankvoorn, snoekbaars en brasem. Ook bot wordt relatief veel bijgevangen, maar deze soort mag gewoon worden aangevoerd. Het vistuigtype met de grootste bijvangst per visserij-inspanning is de hokfuik. Het vistuigtype met de kleinste bijvangst is de korf. De schietfuik heeft de intermediaire positie. Er is een aanzienlijk verschil in bijvangst tussen de beide schietfuikenvissers. De reden hiervan zou de invloed van de visserijlocaties kunnen zijn, maar dit kan niet worden geverifieerd omdat daarvoor de informatie ontbreekt.

Het aandeel op gewichtsbasis van de zes door de vissers geregistreerde vissoorten is weergegeven in Figuur 4. Er komen aanzienlijk verschillen naar voren. Schieraal wordt niet of nauwelijks bijgevangen in korf en hokfuik, maar wel in de beide schietfuikentypen. Snoekbaars, blankvoorn en brasem heeft een klein aandeel in de bijvangst van korven, maar dat geldt niet voor hokfuiken en schietfuiken. 


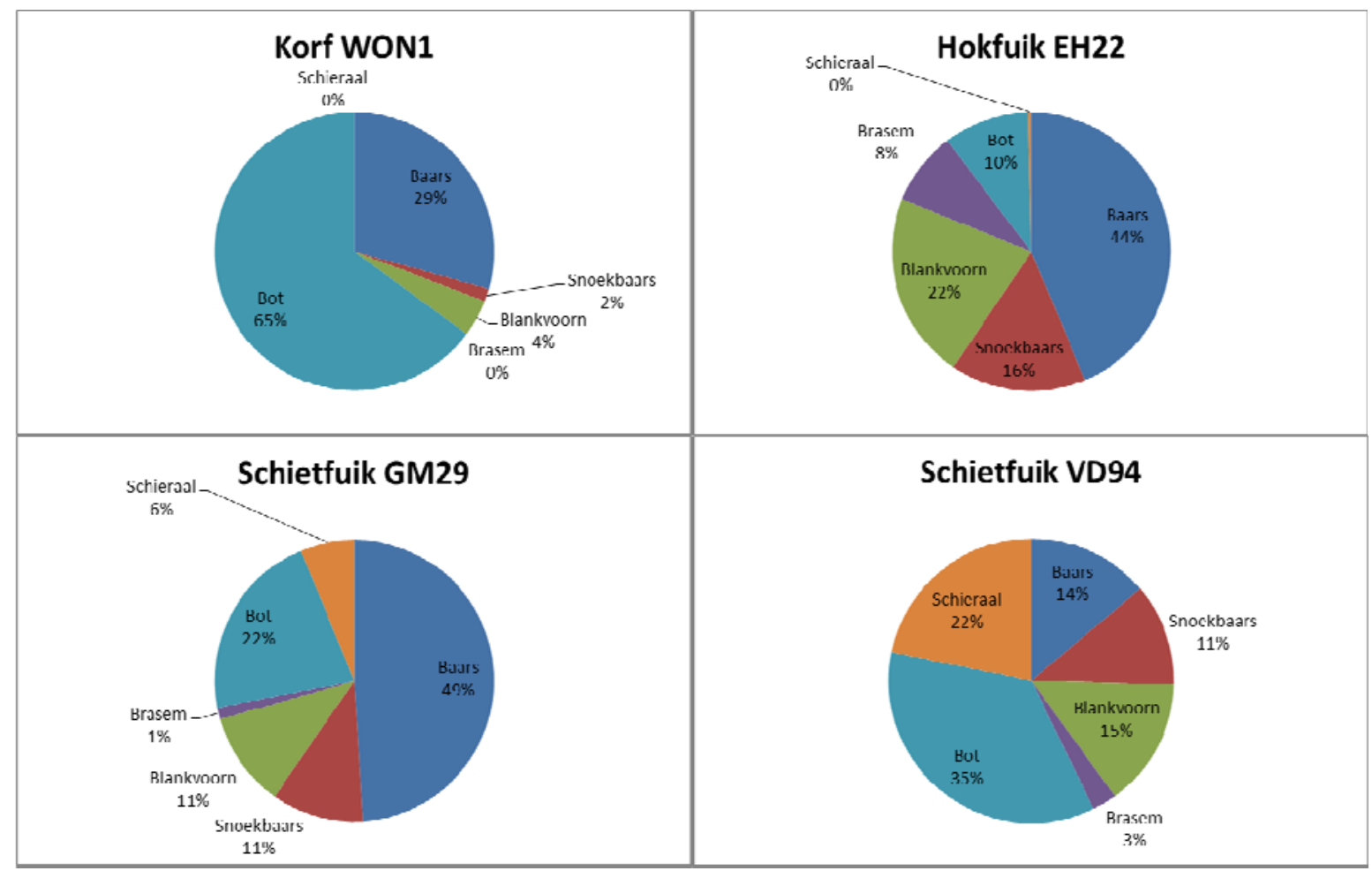

Figuur 4 Soortensamenstelling bijvangst van vis op basis van gewicht in korf, hokfuik, schietfuik (2x) zoals geregistreerd door vissers in VRS.

\subsubsection{Bijvangst ten opzichte van vangst op basis van VRS}

De bijvangst in gewicht van vis ten opzichte van de vangst van wolhandkrab is vermeld in Tabel 16 . Er zijn per vistuigtype en vissoort vaak grote verschillen in bijvangst. De bijvangst is het kleinste bij de korven, namelijk minder dan 20\%. Het verschil in de bijvangst tussen de twee schietfuik-schip combinaties is opvallend. De bijvangst is daarbij voor de meeste vissoorten veel groter in de schietfuiken van de GM29. Een verklaring zou kunnen zijn dat er minder vis ontsnapt door een grofmazig ruif dan door een grofmazige achterste kub.

Tabel 16 Bijvangst van vis als \% van het gewicht van gevangen wolhandkrab over de gehele onderzoeksperiode door vissers geregistreerd in VRS.

\begin{tabular}{|l|c|c|c|c|}
\hline Soort & Korf WON1 & Hokfuik EH22 & Schietfuik VD94 & Schietfuik GM29 \\
\hline Baars & $5.3 \%$ & $28.9 \%$ & $7.6 \%$ & $74.7 \%$ \\
\hline Snoekbaars & $0.3 \%$ & $10.4 \%$ & $6.3 \%$ & $16.2 \%$ \\
\hline Blankvoorn & $0.8 \%$ & $14.4 \%$ & $8.0 \%$ & $16.6 \%$ \\
\hline Brasem & $0.0 \%$ & $5.7 \%$ & $1.5 \%$ & $2.1 \%$ \\
\hline Schieraal & $0.0 \%$ & $0.2 \%$ & $11.9 \%$ & $9.5 \%$ \\
\hline Bot & $11.7 \%$ & $6.6 \%$ & $19.4 \%$ & $33.2 \%$ \\
\hline
\end{tabular}

\subsubsection{Bijvangst van vogels op basis van VRS}

De bijvangst van vogels in de geteste vistuigen is weergegeven als aantal slachtoffers per soort en per visreis tijdens het onderzoek (Tabel 17), alsmede op basis van de visserij-inspanning over de gehele onderzoeksperiode (Tabel 18). 
Tabel 17 Visreizen met bijvangst van vogels.

\begin{tabular}{|l|l|l|c|c|}
\hline \multirow{2}{*}{ Vistuigtype } & \multirow{2}{*}{ Schip } & \multirow{2}{*}{ Datum } & \multicolumn{2}{|c|}{ Bijvangst vogels } \\
\cline { 3 - 5 } & & & Soort & Aantal \\
\hline Aangepaste hokfuik & $\mathrm{EH} 22$ & $4-\mathrm{feb}$ & Fuut & 2 \\
\hline Aangepaste hokfuik & $\mathrm{EH} 22$ & $4-\mathrm{feb}$ & Aalscholver & 1 \\
\hline Aangepaste hokfuik & $\mathrm{EH} 22$ & $12-\mathrm{feb}$ & Aalscholver & 4 \\
\hline Aangepaste hokfuik & $\mathrm{EH} 22$ & $18-\mathrm{feb}$ & Aalscholver & 2 \\
\hline Aangepaste hokfuik & EH22 & $25-\mathrm{feb}$ & Aalscholver & 3 \\
\hline Aangepaste hokfuik & EH22 & $10-\mathrm{mrt}$ & Aalscholver & 1 \\
\hline Aangepaste schietfuik & VD94 & $26-\mathrm{feb}$ & Kuifeend & 1 \\
\hline Aangepaste schietfuik & VD94 & $14-\mathrm{mrt}$ & Kuifeend & 1 \\
\hline Aangepaste schietfuik & GM29 & 6-dec & Aalscholver & 2 \\
\hline Aangepaste schietfuik & GM29 & $21-\mathrm{dec}$ & Fuut & 11 \\
\hline
\end{tabular}

Tabel 18 Bijvangst van vogels per vistuigtype in alle visreizen. Bijvangst per visserij-inspanning.

\begin{tabular}{|l|c|c|c|c|}
\hline & $\begin{array}{c}\text { Korf } \\
\text { WON1 }\end{array}$ & $\begin{array}{c}\text { Hokfuik } \\
\text { EH22 }\end{array}$ & $\begin{array}{c}\text { Schietfui } \\
\text { k VD94 }\end{array}$ & $\begin{array}{c}\text { Schietfui } \\
\text { k GM29 }\end{array}$ \\
\hline Aantal aalscholver & 0 & 11 & 0 & 2 \\
\hline Aantal fuut & 0 & 2 & 0 & 11 \\
\hline Aantal kuifeend & 0 & 0 & 2 & 0 \\
\hline Bijvangst aalscholver in 100 vistuigdagen & 0.000 & 0.576 & 0.000 & 0.037 \\
\hline Bijvangst fuut in 100 vistuigdagen & 0.000 & 0.105 & 0.000 & 0.206 \\
\hline Bijvangst kuifeend in 100 vistuigdagen & 0.000 & 0.000 & 0.010 & 0.000 \\
\hline
\end{tabular}

Het totale aantal bijgevangen vogels dat door de vissers is geregistreerd in VRS is 28 . Er zijn 3 vogelsoorten bijgevangen: aalscholver, fuut en kuifeend. Bijvangst trad op in hokfuiken en schietfuiken, maar niet in korven. Opvallend is de bijvangst van 11 futen in de visreis van 21 december 2016 waarin schietfuiken werden opgehaald. De berekende bijvangst van aalscholvers op basis van visserij-inspanning is hoger voor hokfuiken dan die in schietfuiken en vergelijkbaar voor futen, maar dit kan niet significant worden getoetst. Men dient zich te realiseren dat het aantal waarnemingen (visreizen) daarvoor te laag is. Bij 9 van de in totaal 36 visreizen is door de vissers bijvangst van één of meer vogels geregistreerd.

\subsection{Vangstregistratie door waarnemers}

\subsubsection{Visserij-inspanning op basis van waarnemers}

De vissers hebben alleen het gewicht van de gevangen wolhandkrabben gewogen. De waarnemers daarentegen moesten volgens het protocol in ieder geval de breedte van het rugschild van de wolhandkrabben meten, waarmee vervolgens het gewicht kan worden afgeleid. Daarvoor is de rugschildbreedte-gewicht relatie van Czerniejewski (2010) gebruikt. In de praktijk bleek echter dat niet in alle 16 waarnemersreizen de breedte van het rugschild is gemeten. In die gevallen is wel het gewicht van de wolhandkrabben gewogen. Dit is één keer een vergissing geweest, maar zeven keer vanwege praktische overweging gedaan, omdat het aantal wolhandkrabben zeer groot was, waardoor werd besloten het totale gewicht van gehaalde vistuigen te nemen in plaats van het meten van individuele wolhandkrabben. Voor korven zijn er 5 waarnemersreizen met lengte en 1 waarnemersreis met gewicht. Voor de hokfuiken is er 1 waarnemersreis met lengte en 2 waarnemersreizen met gewicht. Voor de schietfuiken kunnen beter de bepalingen van gewicht worden gebruikt. De Wolhandkrabvangst is weergeven op basis van gewicht afgeleid van lengte en gewicht of op basis van 
gewogen gewicht. De visserij-inspanning van de visreizen met een waarnemer aan boord is weergegeven in Tabel 19.

Tabel 19 Visserij inspanning van de visreizen met door de waarnemers gemeten (bij)vangst.

\begin{tabular}{|l|c|c|c|c|}
\hline & Korf WON1 & Hokfuik EH22 & Schietfuik VD94 & Schietfuik GM29 \\
\hline $\begin{array}{l}\text { Visserij inspanning } \\
\text { (aantal vistuigdagen) }\end{array}$ & 2787 & 514.4 & 14694 & 3298 \\
\hline
\end{tabular}

\subsubsection{Vangst van wolhandkrab op basis van waarnemers}

De vangst van wolhandkrab is weergegeven in gewicht op verschillende momenten in het onderzoek (Figuur 5) en op basis van aantal en gewicht per visserij-inspanning (Tabel 20). De vangst van wolhandkrab lijkt gedurende het jaar af te nemen bij de hokfuik van EH22 en de schietfuik van VD94, terwijl deze iets lijkt toe te nemen bij de korf van WON1 en de schietfuik van GM29. Er kunnen hierbij echter geen harde conclusies worden getrokken vanwege de beperkte omvang van en grote variatie in dit onderzoek.

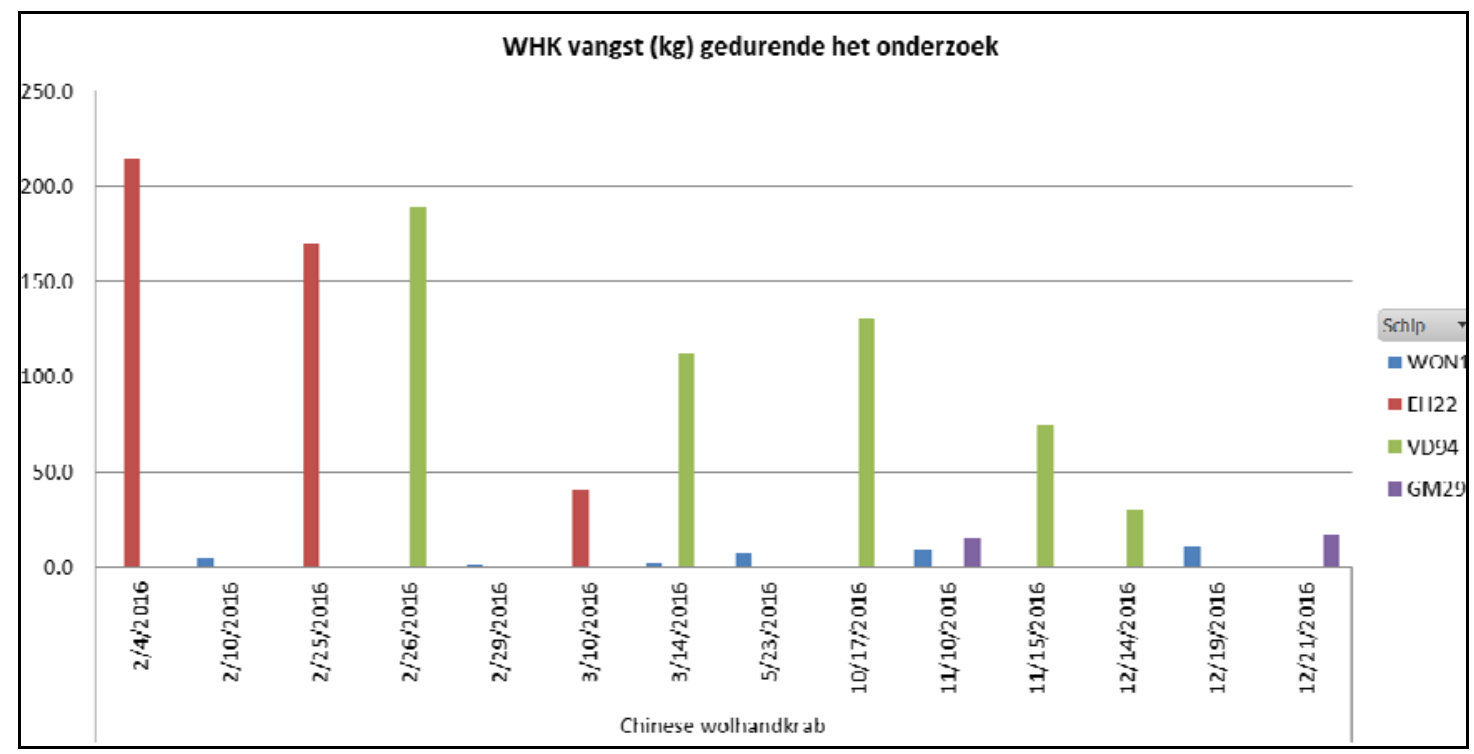

Figuur 5 Vangst van wolhandkrab (in $\mathrm{kg}$ ) gedurende het onderzoek en geregistreerd door waarnemers.

De vangst van wolhandkrab, zowel absoluut als per visserij-inspanning, is het grootste bij hokfuiken en het kleinste bij de korven en de schietfuiken van GM29. De schietfuiken van VD94 hebben een intermediaire positie. Er is een relatief groot verschil tussen de beide schietfuik-schip combinaties betreffende de vangst van wolhandkrab per visserij-inspanning. 
Tabel 20 Vangst van wolhandkrab (WHK) per vistuigtype in alle waarnemersreizen

\begin{tabular}{|l|c|c|c|c|}
\hline Vistuigtype & $\begin{array}{c}\text { Korf } \\
\text { WON1 }\end{array}$ & $\begin{array}{c}\text { Hokfuik } \\
\text { EH22 }\end{array}$ & $\begin{array}{c}\text { Schietfuik } \\
\text { VD94 }\end{array}$ & $\begin{array}{c}\text { Schietfuik } \\
\text { GM29 }\end{array}$ \\
\hline Aantal WHK & 242 & $1569 \#$ & 4476 & 275 \\
\hline Totaal Gewicht WHK (kg) & 35.2 & 424.2 & 536.7 & 32.4 \\
\hline Gem. Gewicht 1 WHK & 0.145 & 0.137 & 0.120 & 0.118 \\
\hline Aantal waarnemersreizen & 6 & 3 & 5 & 2 \\
\hline Visserij inspanning (vistuigdagen) & 2787 & 514.4 & 14694 & 3298 \\
\hline WHK vangst (kg) per 100 vistuigdagen & 1.261 & 82.47 & 3.653 & 0.981 \\
\hline
\end{tabular}

\# Bij de EH22 is bij 2 van de 3 waarnemersreizen het aantal WHK niet bepaald. Daarom is hier van slechts 1 waarnemersreis het aantal WHK vermeld. Het gewicht was $214.6 \mathrm{~kg}$ voor die waarnemersreis van 4 febr. 2016.

\section{Rugschildbreedte verdeling van wolhandkrab}

De verdeling van de rugschildbreedte van de gevangen wolhandkrabben is visueel weergegeven in Figuur 6. Er is relatief weinig verschil waarneembaar tussen de vistuigtypen betreffende de invloed op de rugschildbreedteverdeling. Verreweg de meeste gevangen wolhandkrabben hebben een rugschildbreedte tussen 50 en $82 \mathrm{~mm}$, met de mediane waarde tussen 60 en $64 \mathrm{~mm}$. Opvallend is het grote aantal wolhandkrabben van $60 \mathrm{~mm}$ in de hokfuik. Het lijkt erop dat waarnemers een voorkeur hebben om de lengte van wolhandkrabben af te ronden op 10-tallen (50,60, 70, $80 \mathrm{~mm}$ ). Hier dient men bij de interpretatie van Figuur 6 rekening mee te houden. 


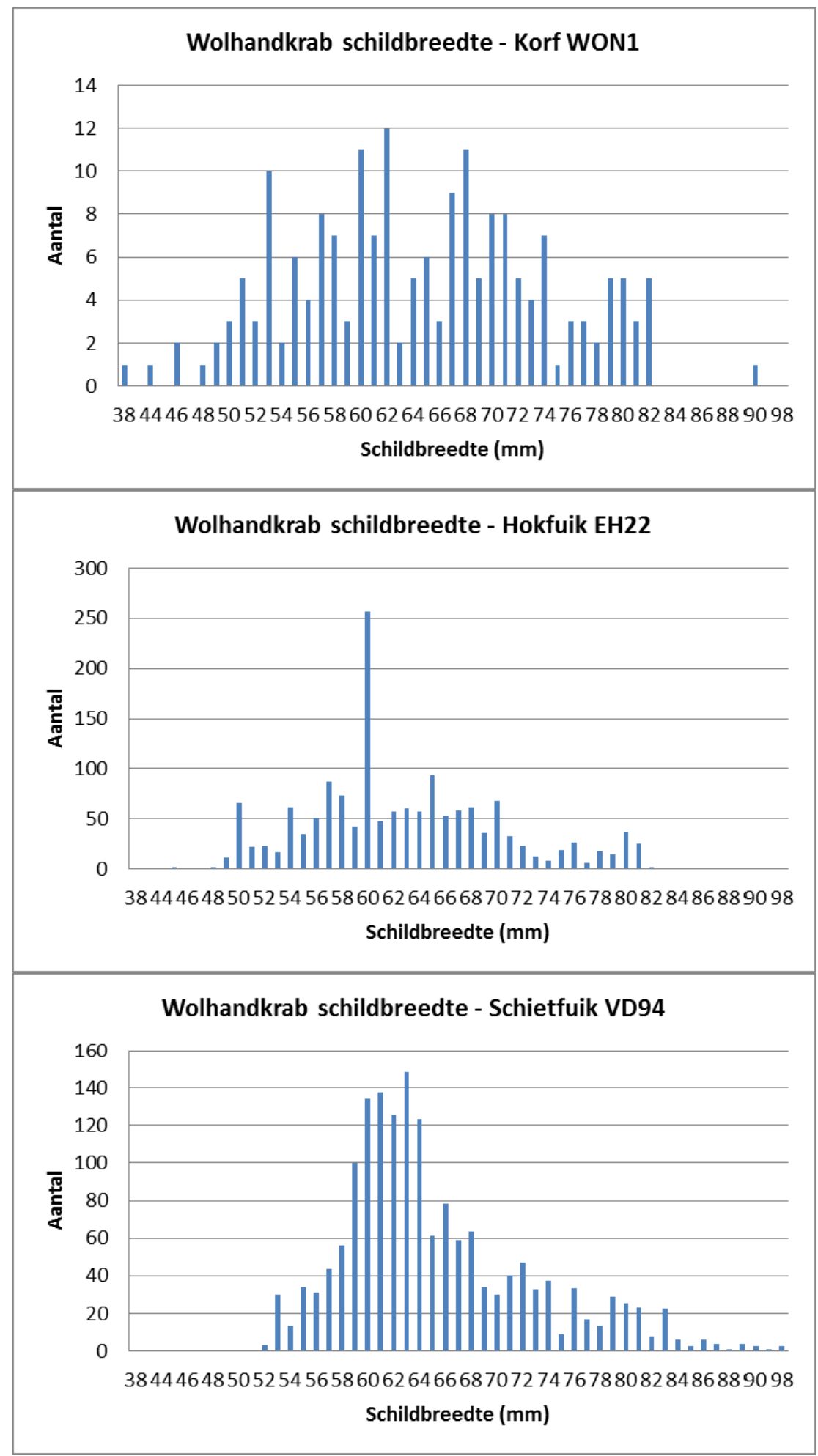

Figuur 6 Rugschildbreedte van wolhandkrabben gevangen met verschillende vistuigtypen en gemeten door waarnemers

\subsubsection{Bijvangst van vis op basis van waarnemers}

De bijvangst van vis is weergegeven als aantal per vissoort op verschillende momenten in het onderzoek (Figuur 7 t/m Figuur 10) en op basis van gewicht per visserij-inspanning (Tabel 21).

Het aantal aangetroffen vissoorten is het hoogste (26) in hokfuik en het laagste (11) in korf, met een tussenpositie (14 en 18) voor schietfuiken. $\mathrm{Er}$ is een groot verschil tussen de vissoorten, maar ook tussen de vistuigtypen betreffende het aantal exemplaren en het gewicht dat is bijgevangen. Ook 
tussen de beide schietfuik-schip combinaties VD94 en GM29 is een groot verschil met veel meer bijvangst door de GM29.

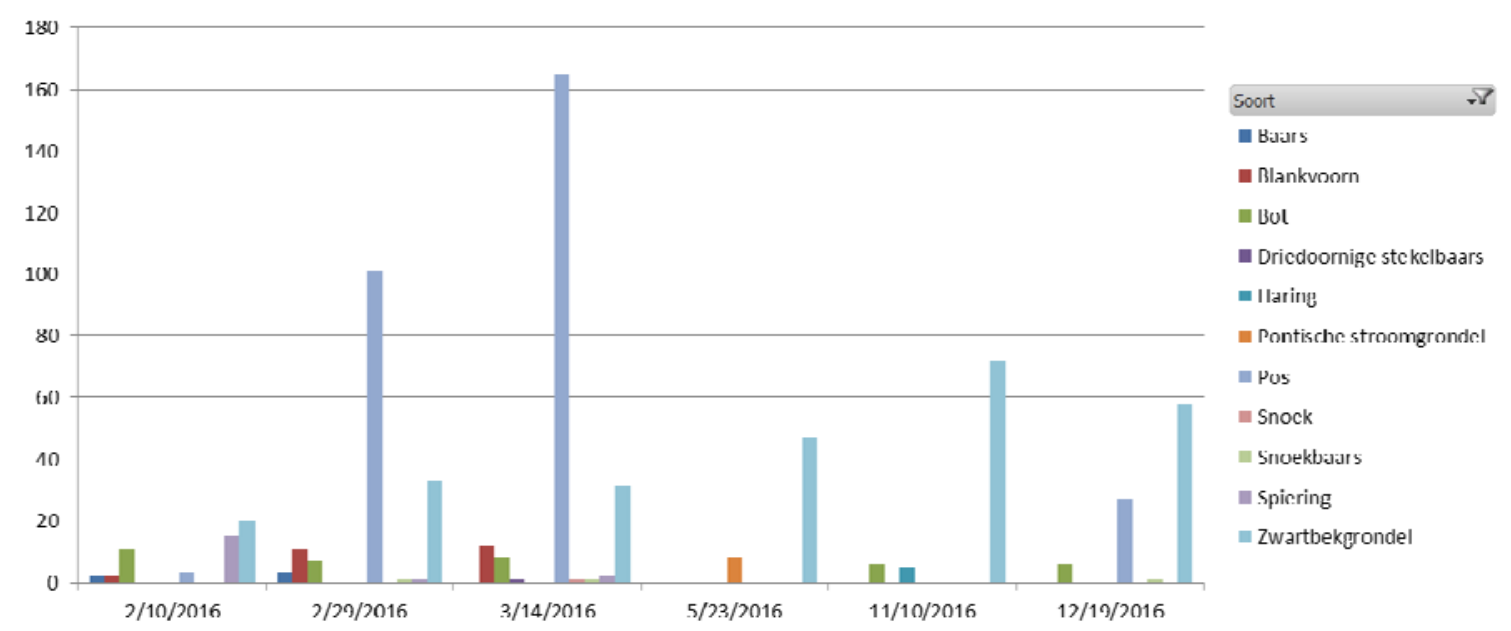

Figuur 7 Bijvangst van vis (aantal) in korven gedurende het seizoen, geregistreerd door waarnemers

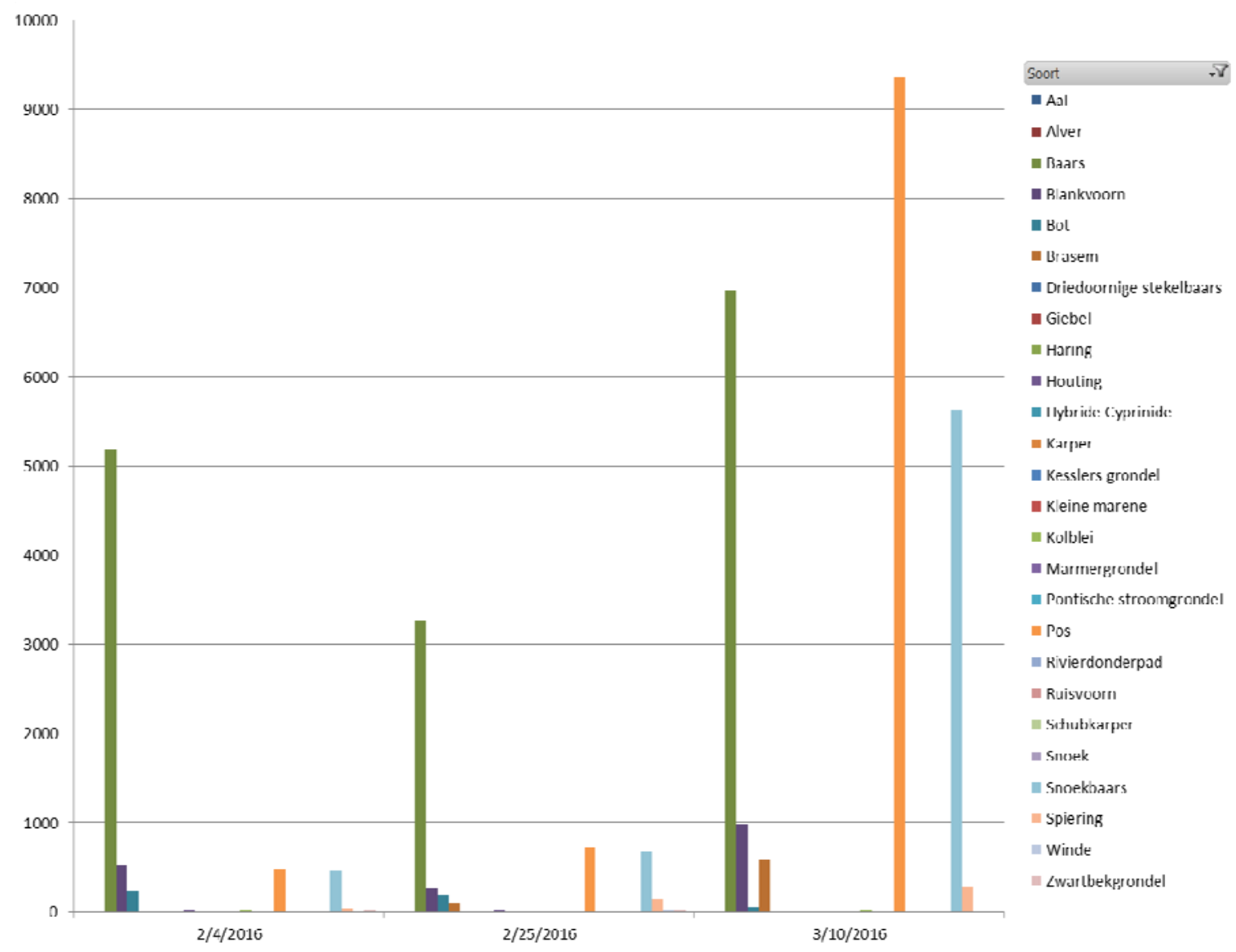

Figuur 8 Bijvangst van vis (aantal) in hokfuiken gedurende het seizoen, geregistreerd door waarnemers 


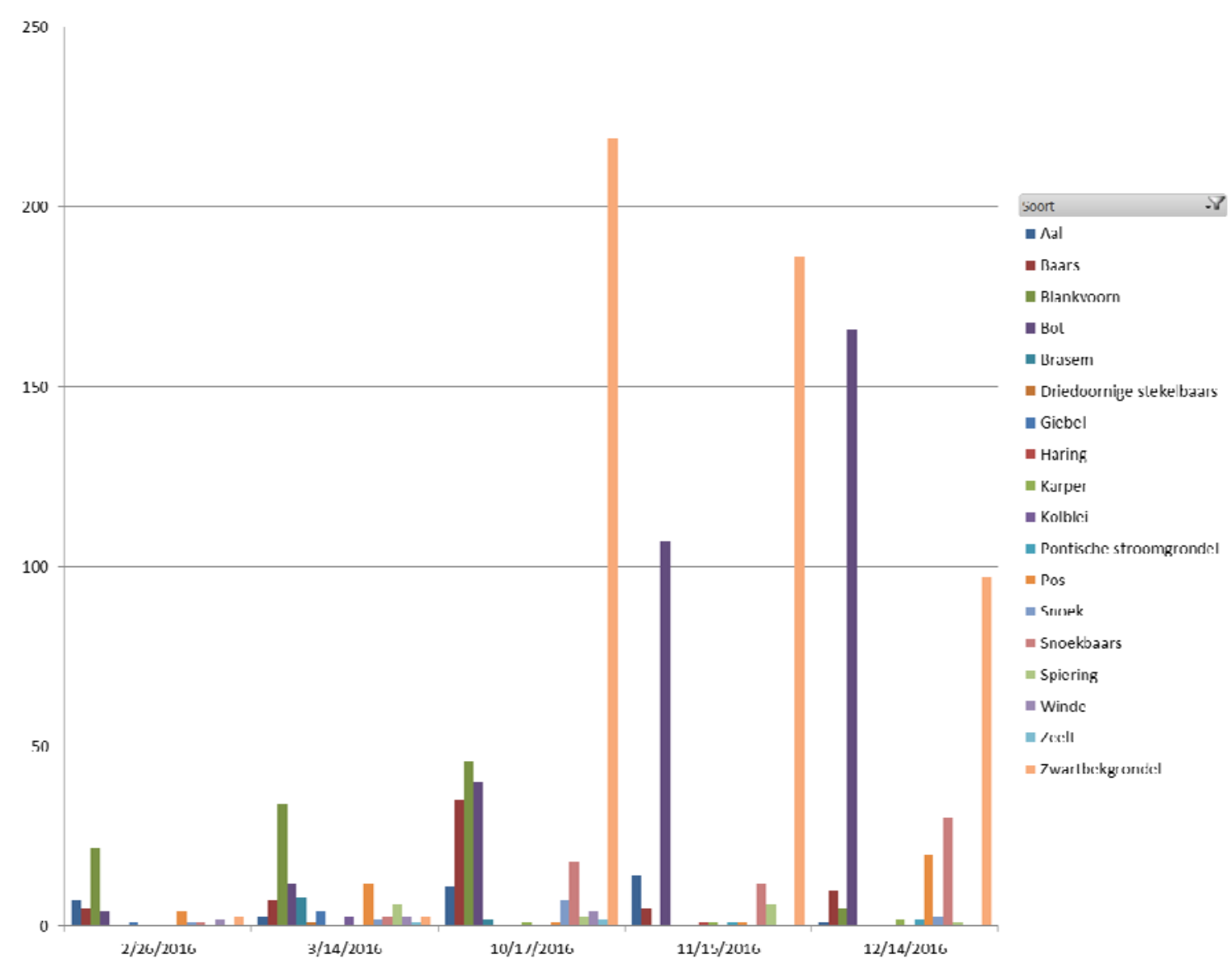

Figuur 9 Bijvangst van vis (aantal) in schietfuiken van VD94 gedurende het seizoen, geregistreerd door waarnemers

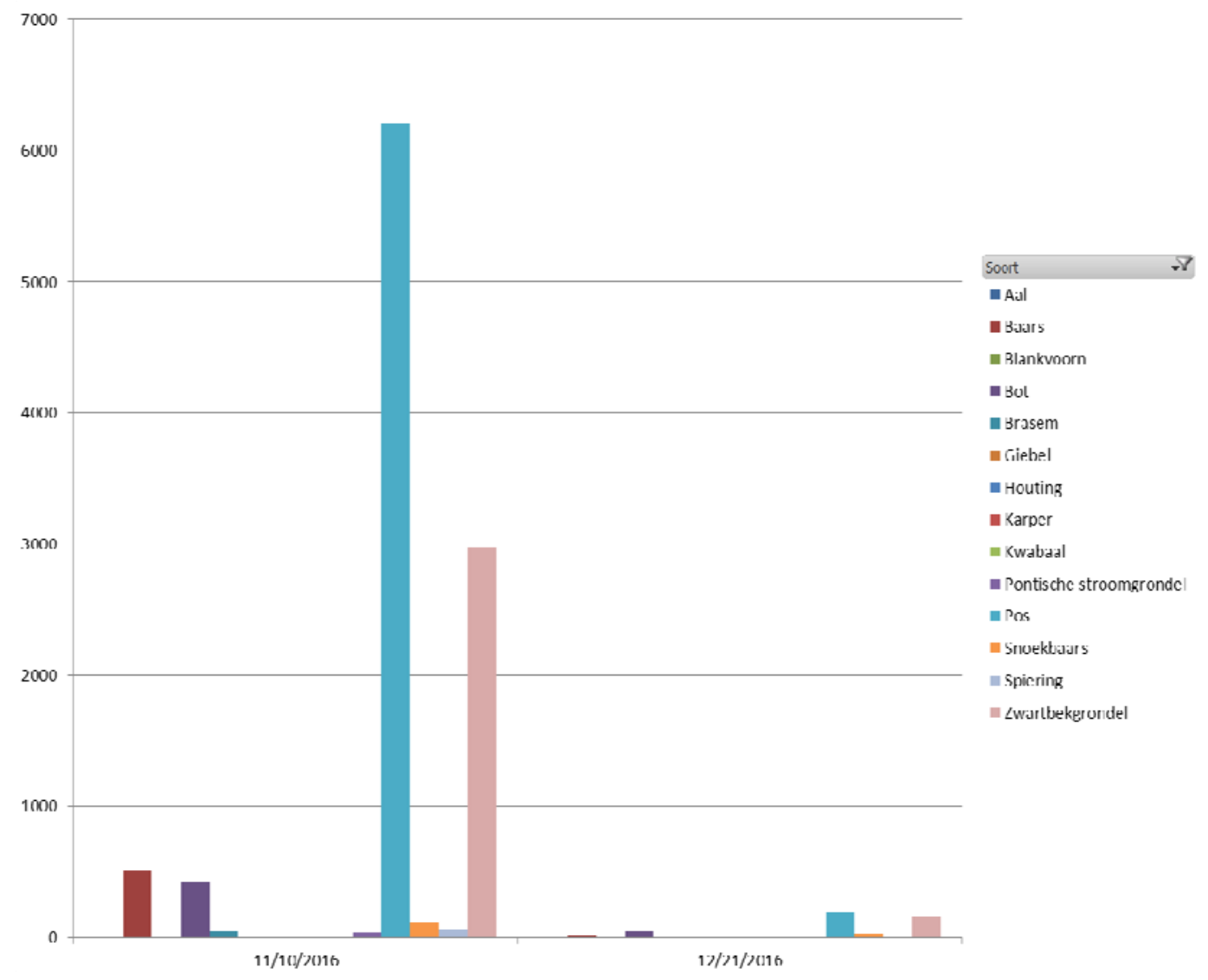

Figuur 10 Bijvangst van vis (aantal) in schietfuiken van GM29 gedurende het seizoen, geregistreerd door waarnemers 
Tabel 21 Bijvangst van vis in gewicht (gram) per soort per vistuig in een vistijd van 100 dagen. Gegevens uit waarnemersreizen.

\begin{tabular}{|c|c|c|c|c|}
\hline Vissoort & $\begin{array}{c}\text { Korf } \\
\text { WON1 }\end{array}$ & $\begin{array}{c}\text { Hokfuik } \\
\text { EH22 }\end{array}$ & $\begin{array}{c}\text { Schietfuik } \\
\text { VD94 }\end{array}$ & $\begin{array}{l}\text { Schietfuik } \\
\text { GM29 }\end{array}$ \\
\hline Aal & 0 & 268 & 188 & 170 \\
\hline Alver & 0 & 6 & 0 & 0 \\
\hline Baars & 2 & 30426 & 97 & 1382 \\
\hline Blankvoorn & 10 & 22791 & 142 & 76 \\
\hline Bot & 116 & 8905 & 514 & 1627 \\
\hline Brasem & 0 & 12022 & 23 & 213 \\
\hline Driedoornige stekelbaars & 0 & 2 & 0 & 0 \\
\hline Giebel & 0 & 175 & 13 & 20 \\
\hline Haring & 1 & 1 & 0 & 0 \\
\hline Houting & 0 & 7949 & 0 & 20 \\
\hline Hybride Cyprinide & 0 & 3 & 0 & 0 \\
\hline Karper & 0 & 55 & 10 & 33 \\
\hline Kesslers grondel & 0 & 58 & 0 & 0 \\
\hline Kleine marene & 0 & 12 & 0 & 0 \\
\hline Kolblei & 0 & 1006 & 3 & 0 \\
\hline Kwabaal & 0 & 0 & 0 & 64 \\
\hline Marmergrondel & 0 & 1 & 0 & 0 \\
\hline Pontische stroomgrondel & 9 & 5 & 1 & 61 \\
\hline Pos & 117 & 29344 & 8 & 4044 \\
\hline Rivierdonderpad & 0 & 3 & 0 & 0 \\
\hline Ruisvoorn & 0 & 18 & 0 & 0 \\
\hline Schubkarper & 0 & 2 & 0 & 0 \\
\hline Snoek & 1 & 1637 & 76 & 0 \\
\hline Snoekbaars & 2 & 26495 & 90 & 545 \\
\hline Spiering & 5 & 814 & 1 & 15 \\
\hline Winde & 0 & 134 & 15 & 0 \\
\hline Zeelt & 0 & 0 & 6 & 0 \\
\hline Zwartbekgrondel & 147 & 119 & 121 & 4099 \\
\hline
\end{tabular}

\subsubsection{Soortensamenstelling van bijvangst}

Het aandeel van de schubvissoorten op basis van aantal en gewicht in de bijvangst van de door de waarnemers geregistreerde vissoorten is weergegeven in Figuur 11 en Figuur 12. Er komen aanzienlijke verschillen naar voren. Bij elk van de 4 onderzochte vistuig-schip combinaties zijn er 2 vissoorten die de bijvangst qua aantal domineren. Dit zijn pos en zwartbekgrondel bij korf WON1 en schietfuik GM29, zwartbekgrondel en bot bij schietfuik VD94 en baars en pos bij hokfuik EH22.

De 4 commerciële schubvissoorten (baars, snoekbaars, blankvoorn, brasem) hebben een beperkt aandeel (aantal en gewicht) in de totale bijvangst bij korf (resp. 5\% en 4\%), schietfuik VD94 (20\% en $28 \%$ ) en schietfuik GM29 (7\% en 4\%), maar een groot aandeel bij hokfuik (ca. 69 en 66\%).

Schieraal wordt het meeste bijgevangen in schietfuik VD94 (aantal 3\% en gewicht 15\%). 


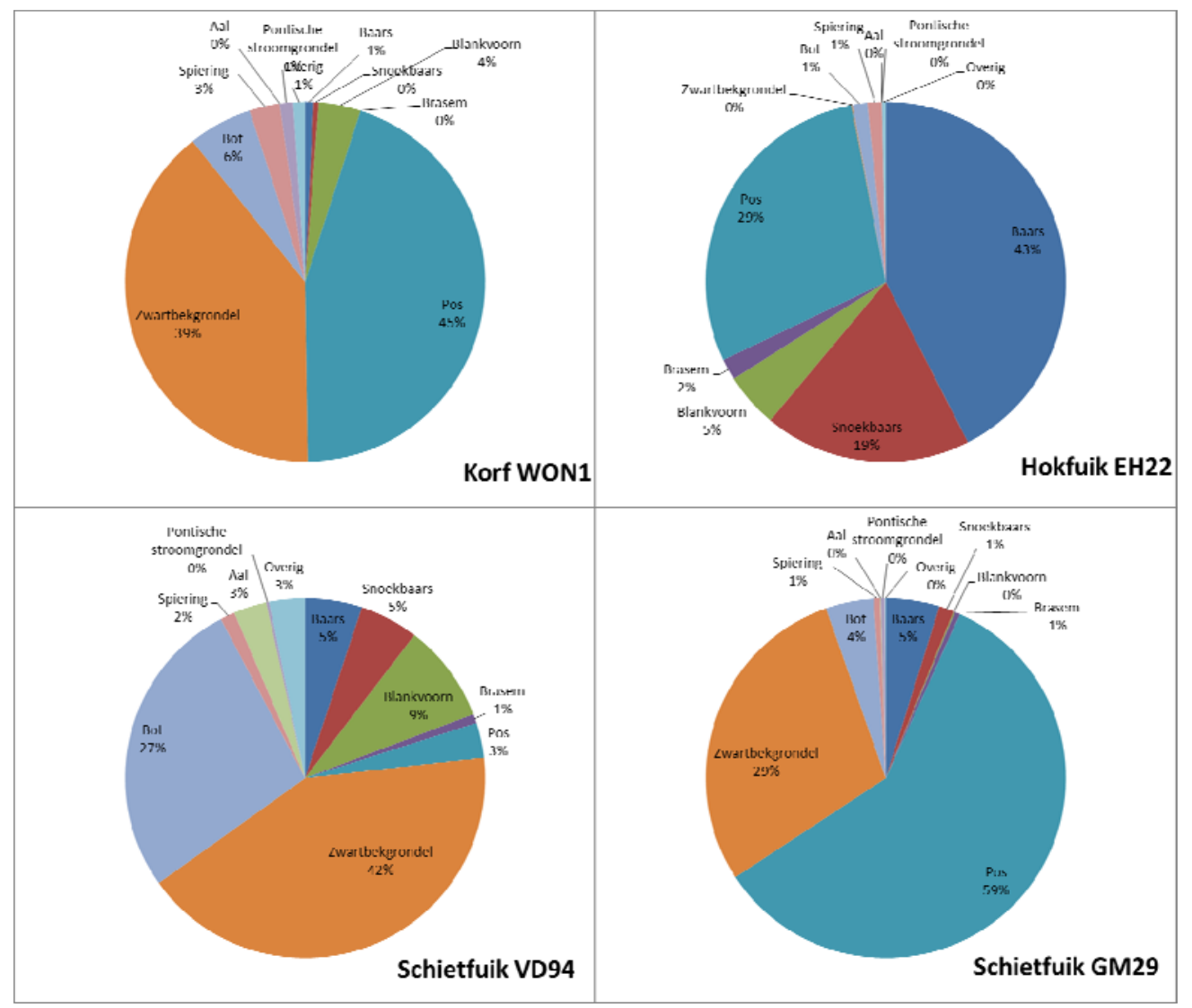

Figuur 11: Soortensamenstelling bijvangst van vis op basis van aantal in korf, hokfuik, schietfuik (2x) zoals geregistreerd door waarnemers.

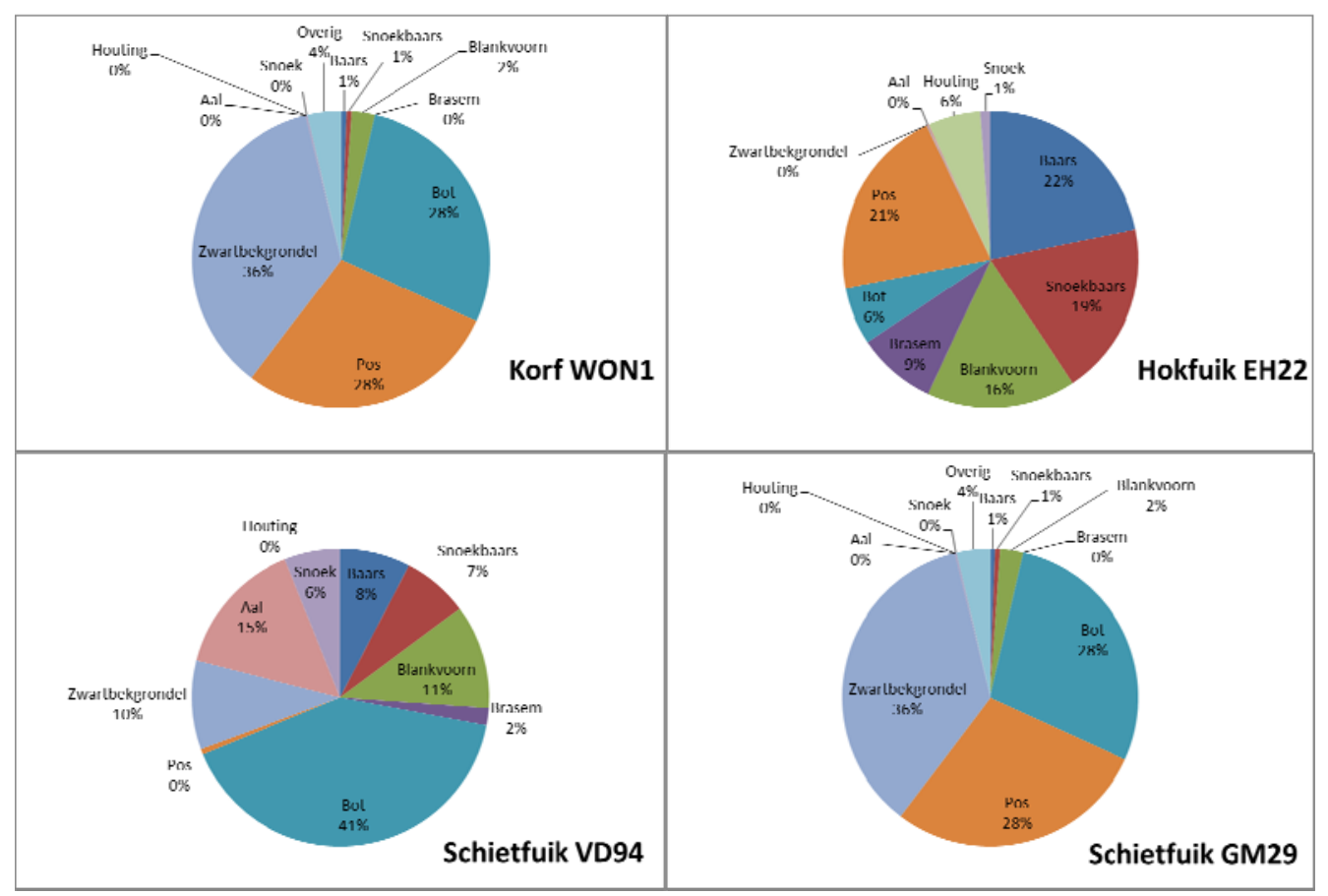

Figuur 12: Soortensamenstelling bijvangst van vis op basis van gewicht in korf, hokfuik, schietfuik $(2 x)$ zoals geregistreerd door waarnemers.

\subsubsection{Lengte verdeling van bijvangstsoorten}

De lengteverdeling van de bijgevangen commerciële schubvissoorten baars, snoekbaars, blankvoorn en brasem in elk van de 4 onderzochte vistuig-schip combinaties staat in Figuur 13 t/m Figuur 16. Met korf en hokfuik worden over het algemeen kleinere vissen bijgevangen dan met de schietfuiken. 
Blijkbaar zijn deze kleine vissen niet in staat uit de vistuigen te ontsnappen via de ruif of grotere maaswijdte, terwijl dat fysiek wel mogelijk zou moeten zijn afgaande op de maaswijdte daarvan. In sommige situaties worden er 2 lengtegroepen van een soort bijgevangen, zoals bij blankvoorn en brasem in hokfuik. Er wordt nauwelijks grote snoekbaars ( $>42 \mathrm{~cm}$ ) bijgevangen. Alleen met schietfuiken worden nog grote baars ( $>22 \mathrm{~cm}$ ) bijgevangen.

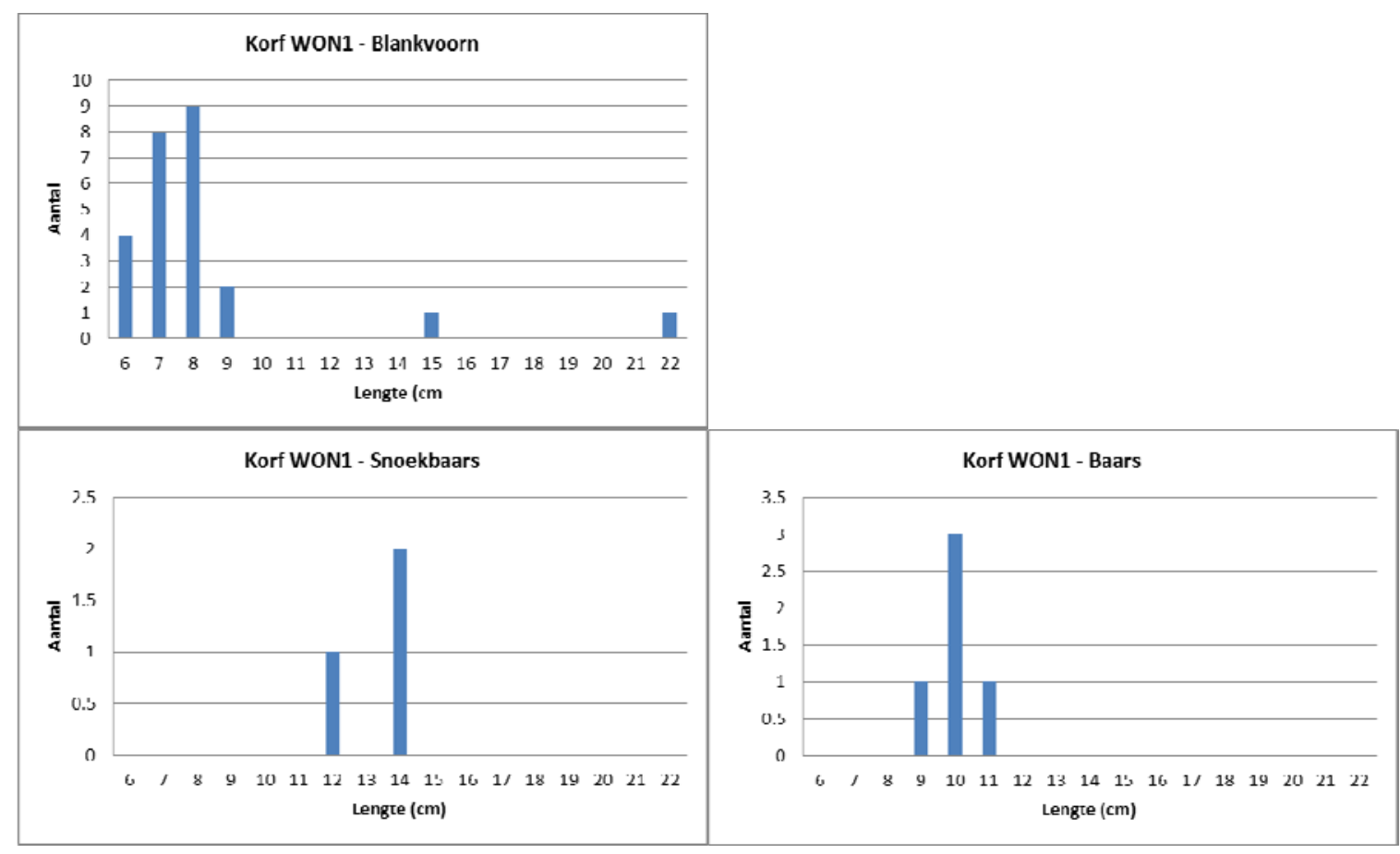

Figuur 13 Lengte verdeling van de commerciële schubvissoorten gevangen met korven van de WON1 en gemeten door waarnemers

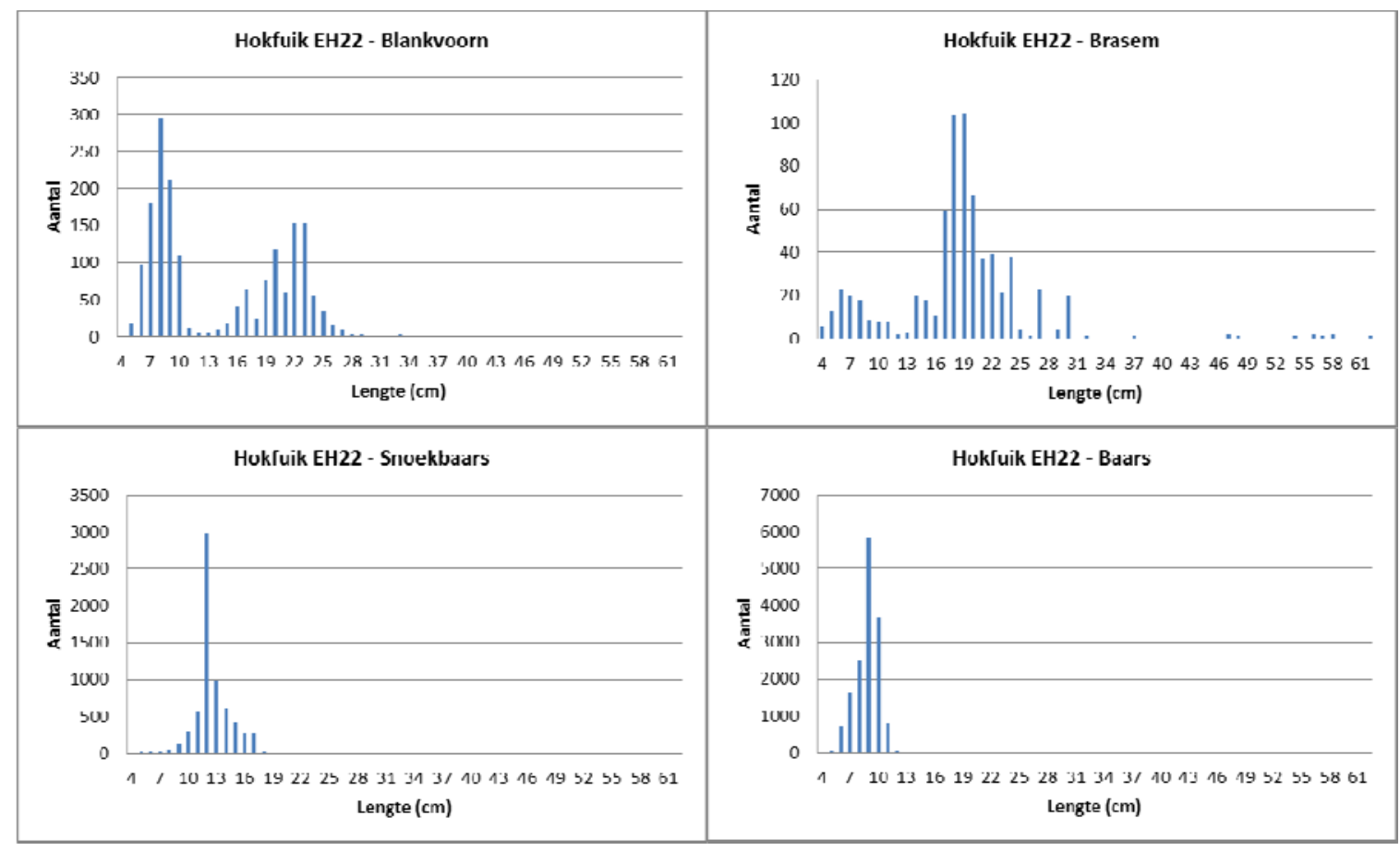

Figuur 14 Lengte verdeling van de commerciële schubvissoorten gevangen met hokfuiken van de $\mathrm{EH} 22$ en gemeten door waarnemers 


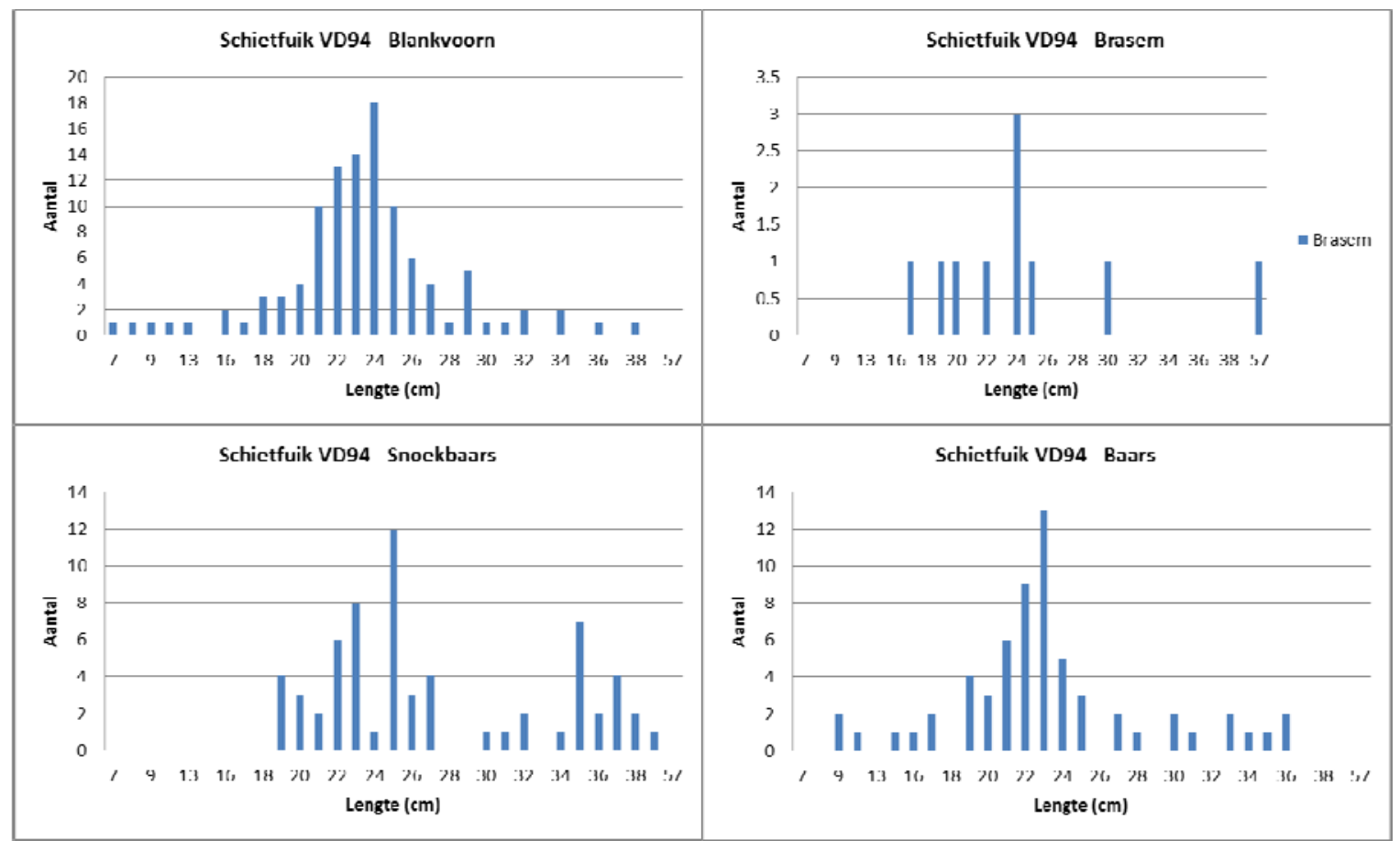

Figuur 15 Lengte verdeling van de commerciële schubvissoorten gevangen met schietfuiken van de VD94 en gemeten door waarnemers

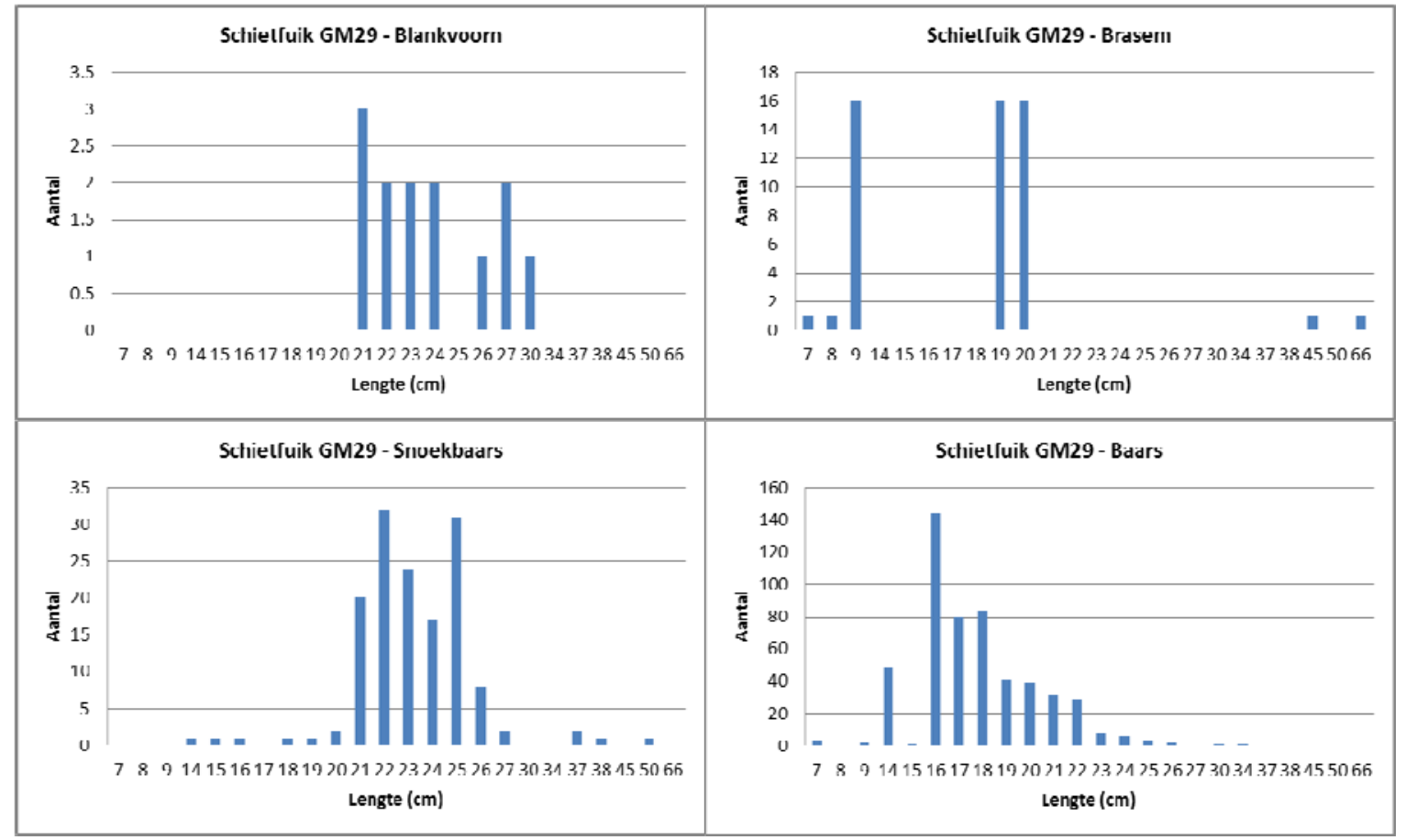

Figuur 16 Lengte verdeling van de commerciële schubvissoorten gevangen met schietfuiken van de GM29 en gemeten door waarnemers

\subsubsection{Bijvangst ten opzichte van vangst}

In Tabel 22 en Tabel 23 staan de vissoorten vermeld die in minimaal één van de vistuigtypen minimaal $1 \%$ van het aantal of gewicht van de gevangen wolhandkrab uitmaken. Dit geldt voor respectievelijk 12 en 15 soorten. 
Tabel 22 Bijvangst uitgedrukt als \% van het aantal gevangen wolhandkrab over de gehele onderzoeksperiode, bepaald door waarnemers

\begin{tabular}{|l|c|c|c|c|}
\hline Soort & Korf WON1 & Hokfuik EH22 & Schietfuik VD94 & Schietfuik GM29 \\
\hline Aal & - & $0.0 \%$ & $0.8 \%$ & $2.5 \%$ \\
\hline Baars & $2.1 \%$ & $290 \%$ & $1.4 \%$ & $190 \%$ \\
\hline Blankvoorn & $10 \%$ & $34 \%$ & $2.4 \%$ & $4.7 \%$ \\
\hline Bot & $15 \%$ & $9.2 \%$ & $7.4 \%$ & $170 \%$ \\
\hline Brasem & - & $13 \%$ & $0.2 \%$ & $19 \%$ \\
\hline Haring & $2.1 \%$ & $0.0 \%$ & $0.02 \%$ & - \\
\hline Karper & - & $0.0 \%$ & $0.1 \%$ & $2.2 \%$ \\
\hline Pontische stroomgrondel & $3.3 \%$ & $0.0 \%$ & $0.1 \%$ & $14 \%$ \\
\hline Pos & $122 \%$ & $199 \%$ & $0.8 \%$ & $2323 \%$ \\
\hline Snoekbaars & $1.2 \%$ & $127 \%$ & $1.4 \%$ & $53 \%$ \\
\hline Spiering & $7.4 \%$ & $8.8 \%$ & $0.4 \%$ & $23 \%$ \\
\hline Zwartbekgrondel & $108 \%$ & $0.6 \%$ & $11 \%$ & $1138 \%$ \\
\hline
\end{tabular}

Tabel 23 Bijvangst uitgedrukt als \% van het gewicht van gevangen wolhandkrab over de gehele onderzoeksperiode bepaald door waarnemers

\begin{tabular}{|l|c|c|c|c|}
\hline Soort & Korf WON1 & Hokfuik EH22 & Schietfuik VD94 & Schietfuik GM29 \\
\hline Aal & $0.0 \%$ & $0.3 \%$ & $5.2 \%$ & $17 \%$ \\
\hline Baars & $0.2 \%$ & $37 \%$ & $2.6 \%$ & $141 \%$ \\
\hline Blankvoorn & $0.8 \%$ & $28 \%$ & $3.9 \%$ & $7.8 \%$ \\
\hline Bot & $9.2 \%$ & $11 \%$ & $14 \%$ & $166 \%$ \\
\hline Brasem & $0.0 \%$ & $15 \%$ & $0.6 \%$ & $22 \%$ \\
\hline Giebel & $0.0 \%$ & $0.2 \%$ & $0.3 \%$ & $2.1 \%$ \\
\hline Houting & $0.0 \%$ & $9.6 \%$ & $0.0 \%$ & $2.0 \%$ \\
\hline Karper & $0.0 \%$ & $0.1 \%$ & $0.3 \%$ & $3.4 \%$ \\
\hline Kolblei & $0.0 \%$ & $1.2 \%$ & $0.1 \%$ & $0.0 \%$ \\
\hline Pontische stroomgrondel & $0.7 \%$ & $0.0 \%$ & $0.0 \%$ & $6.2 \%$ \\
\hline Pos & $9.3 \%$ & $36 \%$ & $0.2 \%$ & $412 \%$ \\
\hline Snoek & $0.1 \%$ & $2.0 \%$ & $2.1 \%$ & $0.0 \%$ \\
\hline Snoekbaars & $0.2 \%$ & $32 \%$ & $2.5 \%$ & $56 \%$ \\
\hline Spiering & $0.4 \%$ & $1.0 \%$ & $0.0 \%$ & $1.6 \%$ \\
\hline Zwartbekgrondel & $12 \%$ & $0.1 \%$ & $3.3 \%$ & $418 \%$ \\
\hline
\end{tabular}

De bijvangst van vis relatief ten opzichte van Wolhandkrab is voor de meeste soorten groter op basis van aantal dan op gewicht. De bijvangst is het grootste in hokfuik en schietfuik van de GM29. De bijvangst is het kleinste in korven. De bijvangst is intermediair in de schietfuiken van VD94. Er wordt een groot verschil in bijvangst geconstateerd tussen de schietfuiken van de VD94 en de GM29.

Bovengeschetst beeld geldt ook voor de 4 commerciële schubvissoorten. De totale bijvangst op gewichtsbasis van deze 4 soorten is $111 \%$ bij EH22, 9.6\% bij VD94 en $1.2 \%$ bij WON1. Van deze soorten is de bijvangst van brasem meestal het kleinste.

\subsubsection{Bijvangst van vogels}

Er zijn drie vogelsoorten bijgevangen: aalscholver, fuut en kuifeend tijdens de waarnemersreizen. De bijvangst van aalscholver en fuut op basis van visserij-inspanning is hoger voor hokfuik, maar dit kan 
niet significant worden getoetst aangezien het aantal waarnemingen daarvoor te laag is. Bij zes van de 16 visreizen met een waarnemer aan boord is bijvangst van één of meer vogels geconstateerd.

Tabel 24 Bijvangst van vogels per vistuigtype in alle waarnemersreizen. Verdeling over de periode van het onderzoek.

\begin{tabular}{|l|l|l|c|c|}
\hline \multirow{2}{*}{ Vistuigtype } & \multirow{2}{*}{ Schip } & \multirow{2}{*}{ Datum } & \multicolumn{2}{|c|}{ Bijvangst vogels } \\
\cline { 4 - 5 } & & & Soort & Aantal \\
\hline Aangepaste hokfuik & EH22 & 4-feb & Fuut & 2 \\
\hline Aangepaste hokfuik & EH22 & 4-feb & Aalscholver & 1 \\
\hline Aangepaste hokfuik & EH22 & $25-\mathrm{feb}$ & Aalscholver & 3 \\
\hline Aangepaste hokfuik & EH22 & $10-\mathrm{mrt}$ & Aalscholver & 1 \\
\hline Aangepaste schietfuik & VD94 & $26-\mathrm{feb}$ & Kuifeend & 1 \\
\hline Aangepaste schietfuik & VD94 & 14-mrt & Kuifeend & 1 \\
\hline Aangepaste schietfuik & GM29 & 21-dec & Fuut & 11 \\
\hline
\end{tabular}

Tabel 25 Bijvangst van vogels per vistuigtype in alle waarnemersreizen. Bijvangst per visserijinspanning.

\begin{tabular}{|l|c|c|c|c|}
\hline & $\begin{array}{c}\text { Korf } \\
\text { WON1 }\end{array}$ & $\begin{array}{c}\text { Hokfuik } \\
\text { EH22 }\end{array}$ & $\begin{array}{c}\text { Schietfuik } \\
\text { VD94 }\end{array}$ & $\begin{array}{c}\text { Schietfuik } \\
\text { GM29 }\end{array}$ \\
\hline Aantal bijgevangen aalscholver & 0 & 5 & 0 & 0 \\
\hline Aantal bijgevangen fuut & 0 & 2 & 0 & 11 \\
\hline Aantal bijgevangen kuifeend & 0 & 0 & 2 & 0 \\
\hline Bijvangst aalscholver per 100 vistuigdagen & 0.000 & 0.972 & 0.000 & 0.000 \\
\hline Bijvangst fuut per 100 vistuigdagen & 0.000 & 0.389 & 0.000 & 0.334 \\
\hline Bijvangst kuifeend per 100 vistuigdagen & 0.000 & 0.000 & 0.014 & 0.000 \\
\hline
\end{tabular}

\subsection{Vergelijking vangstregistratiemethoden}

\subsubsection{Vangst van wolhandkrab}

De relatie tussen de wolhandkrabvangst geregistreerd door vissers en geregistreerd door waarnemers is onderzocht door deze visueel weer te geven voor de visreizen waarvoor beide type bepalingen metingen zijn gedaan (zie Figuur 17). Het blijkt dat er een redelijke overeenkomst bestaat. 


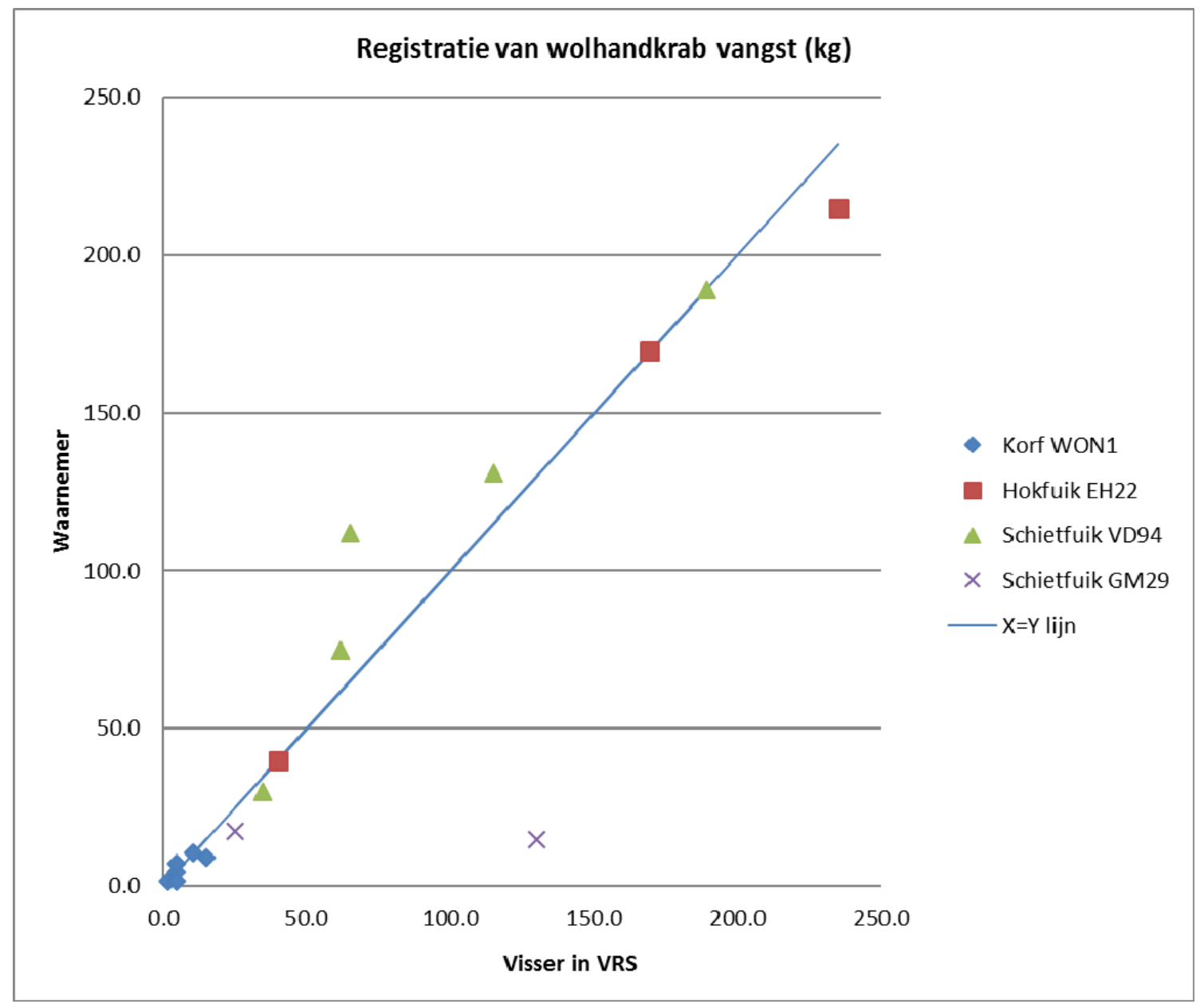

Figuur 17 Relatie tussen de vangst $(\mathrm{kg})$ van wolhandkrab, geregistreerd door vissers in VRS en door waarnemers. Zestien visreizen. Lineaire trendline: $y=0.9108 x ; R^{2}=0.8176$. Ter vergelijking is de $X=Y \operatorname{lijn}(1$ op 1 lijn) in de figuur geplot. 


\subsubsection{Bijvangst van vis}

De relatie tussen de bijvangst geregistreerd door vissers en geregistreerd door waarnemers is onderzocht door deze visueel weer te geven voor de visreizen waarvoor beide type bepalingen metingen zijn gedaan. Dit is gedaan voor elk van de 4 commerciële schubvissoorten en 2 andere commerciële vissoorten (Figuur 18) en van de 6 soorten gecombineerd (Figuur 19). Het blijkt dat er over het algemeen een redelijke overeenkomst bestaat tussen het resultaat van de waarnemingen van vissers en waarnemers. Zie daarvoor Figuur 19 waaruit blijkt dat de verhouding bijna 1 is, en de correlatie matig is. Tussen de vissoorten bestaat hierbij variatie. Bij baars en aal schatten vissers de bijvangst hoger in dan de waarnemers. De correlatie is goed bij baars, blankvoorn en brasem; matig bij snoekbaars en aal en slecht bij bot.

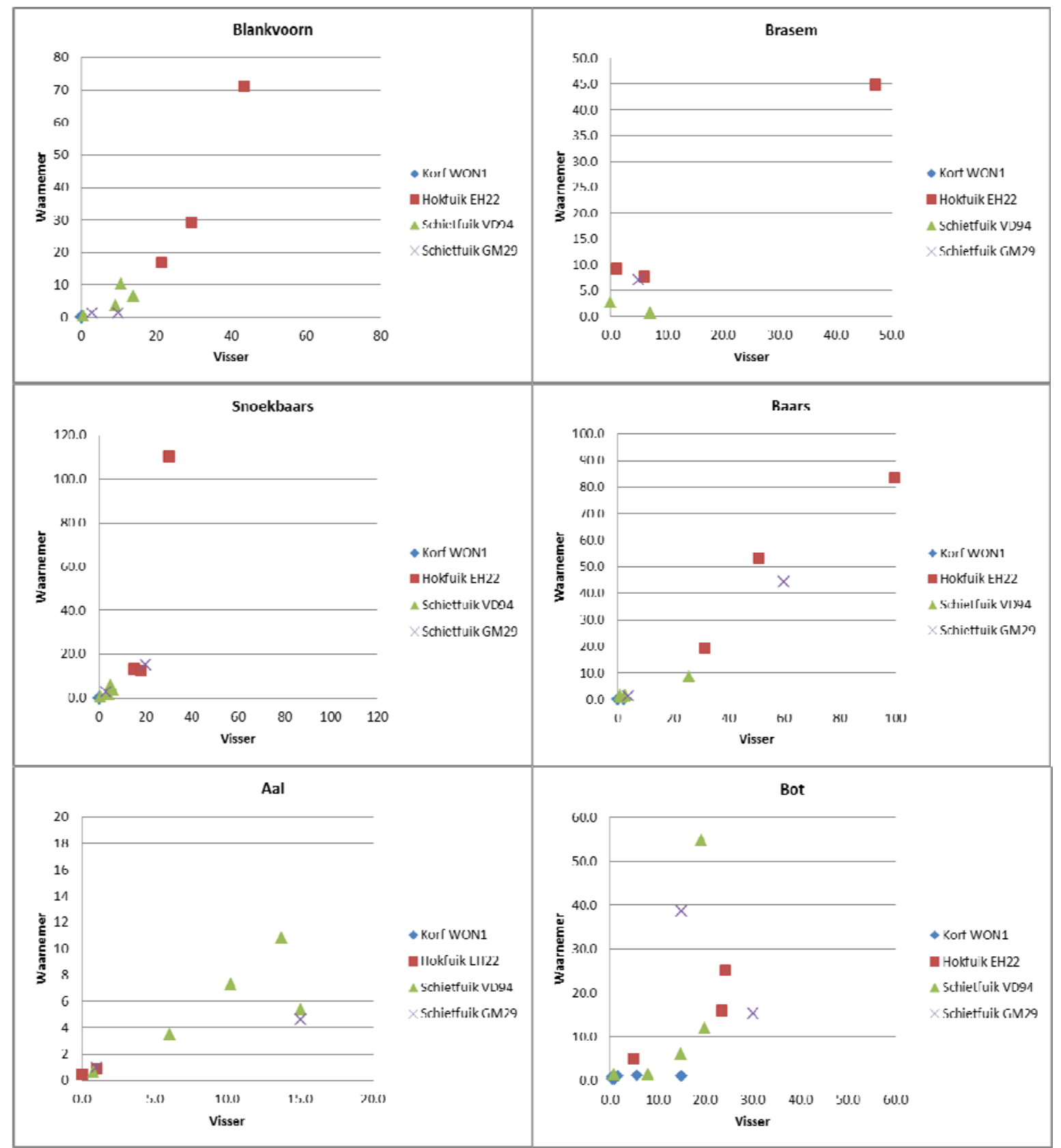

Figuur 18 Relatie tussen de bijvangst $(\mathrm{kg})$ geregistreerd door vissers in VRS en waarnemers betreffende de afzonderlijke soorten: baars, blankvoorn, snoekbaars, brasem, aal en bot. Zestien visreizen. 


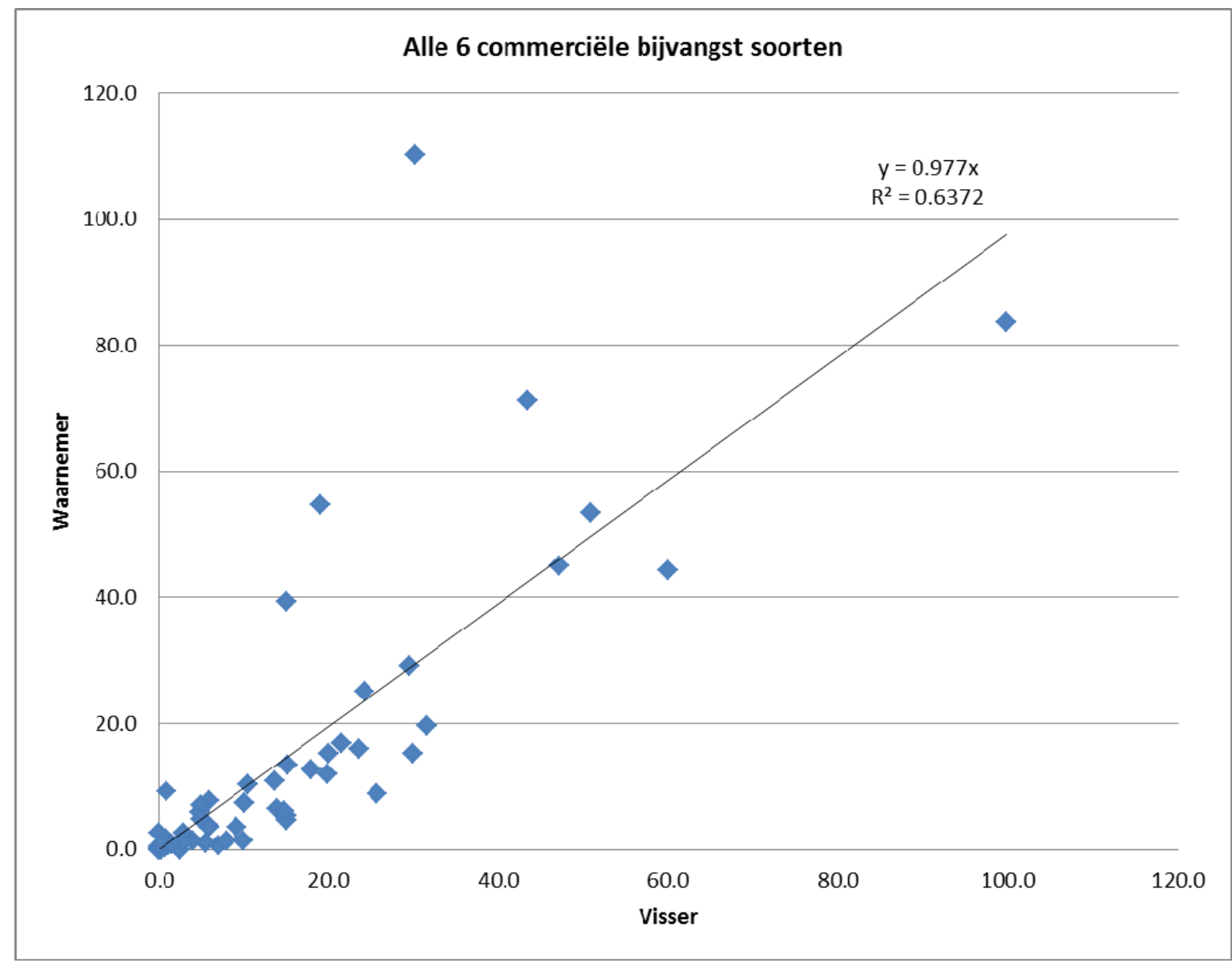

Figuur 19 Relatie tussen de bijvangstregistratie door vissers in VRS en waarnemers betreffende de 6 commerciële vissoorten: baars, blankvoorn, snoekbaars, brasem, aal en bot. Zestien visreizen. $R^{2}=$ 0.64

\subsubsection{Verhouding tussen bijvangst en vangst}

De verhouding tussen de bijvangst en de vangst kan worden gebaseerd op de registratie door de vissers en die door de waarnemers. In Figuur 20 is dit weergegeven voor de vissoorten en voor de vistuigtype-schip combinaties. Het blijkt dat deze verhouding voor de bijvangst over het algemeen een factor 2 hoger is voor waarnemer met een matige correlatie.
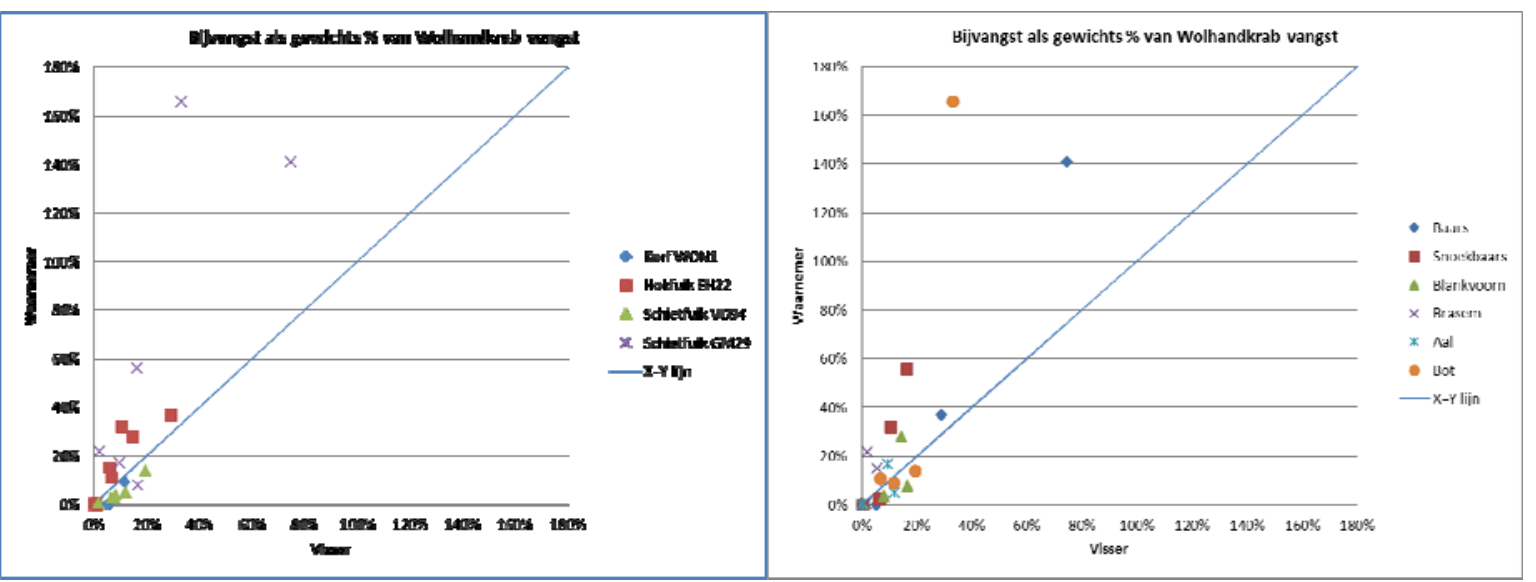

Figuur 20 Relatie tussen de bijvangstregistratie door vissers in VRS en waarnemers betreffende de 4 vistuigtype-schip combinaties (linker figuur) en betreffende het aandeel van de bijvangst op gewichtsbasis t.o.v. de wolhandkrabvangst voor de 6 commerciële vissoorten: baars, blankvoorn, snoekbaars, brasem, aal en bot (rechter figuur). Zestien visreizen. Lineaire trendline: $y=2.11 x ; R^{2}=$ 0.67 . Ter vergelijking is de $X=Y$ lijn ( 1 op 1 lijn) in de figuur geplot. 


\subsubsection{Bijvangst van vogels}

Het aantal bijgevangen vogels is in de 16 waarnemersreizen lager dan dat in de 36 visreizen, maar op basis van de visserij-inspanning is deze groter. Er kan echter geen uitspraak over de statistische significantie worden gedaan vanwege het relatief kleine aantal visreizen. 


\section{Discussie, conclusies en aanbevelingen}

In dit hoofdstuk worden eerst belangrijke aspecten bediscussieerd en conclusies getrokken, dan de kennisvragen uit hoofdstuk 2 beantwoord en vervolgens enkele aanbevelingen gedaan.

\subsection{Wel en niet onderzochte vistuigtypen}

Van de 6 vistuigtypen, waarvoor een ontheffing en een Nb-wetvergunning is aangevraagd en verkregen, zijn er 3 vistuigtypen getest in de pilot, namelijk korven, aangepaste hokfuiken en aangepaste schietfuiken. De andere 3 vistuigtypen, zijnde aangepaste schietfuiken met een buis, verlaagd staandwant, platliggend net, zijn niet getest omdat de vissers die zich daar oorspronkelijk voor hadden aangemeld, uiteindelijk hebben besloten niet te gaan vissen in de pilot. Het aantal deelnemende vissers was klein, namelijk 4. In de voorafgaande inventarisatie en de open inschrijving was de belangstelling van de beroepsvissers van het IJsselmeer wel behoorlijk groot.

De reden die de vissers, die op het laatst afhaakten, voor hun aarzeling opgaven was dat ze eerst de uitspraak van de Raad van State over het verminderen van de staande netten op het IJsselmeer wilden afwachten. Toen de uitspraak van de Raad van State bekend was op 26 april 2016, waren ze niet meer gemotiveerd om deel te nemen aan het onderzoek.

\subsection{Onderzoeksperiode}

De gehele periode waarin er in dit onderzoek kon worden gevist, is wel grotendeels, maar niet volledig benut. Er is namelijk in de eerste 3 weken van januari niet gevist vanwege de vertraging die was opgetreden door het later aanbieden van de samenwerkingsovereenkomst door Wageningen Marine Research. Daarnaast is een deel van de visperiode voor dit onderzoek niet door de korven- en schietfuikenvissers gevist omdat ze verwachtten dat de vangst van wolhandkrab te laag zou zijn om rendabel te zijn. De beide schietfuikenvissers hebben niet gevist in de laatste 10 a 14 dagen van december. De korvenvisser heeft niet gevist in de maanden augustus en september (zie Bijlage 6). De motivatie van de korvenvisser was dat die maanden niet interessant waren voor visserij van Wolhandkrab doordat de te verwachten vangst van wolhandkrab veel lager zal zijn dan in de periode oktober t/m mei (pers. mededeling M. van Malsen). De schietfuikenvisser van de GM29 heeft niet op wolhandkrab gevist in oktober. Voor deze visser was de motivatie dat hij het druk had met een andere en commercieel aantrekkelijke vorm van visserij, waardoor visserij op de wolhandkrab in het IJsselmeer minder aantrekkelijk was (pers. mededeling S. Hoekman).

\subsection{Bruikbaarheid en betrouwbaarheid van de gegevens}

Met betrekking tot de bruikbaar en betrouwbaarheid van de gegevens kan het volgende worden geconcludeerd:

- $\quad$ Er kan geen statistische vergelijking tussen vangtuigtypen worden gemaakt van de selectiviteit (vangst-bijvangst ratio's) vanwege te weinig metingen (n), verschil in locaties, ontbreken van controle vistuigtypen (zonder aanpassing), maar dat was ook al bekend bij aanvang van de pilot.

- Er kan geen statistische analyse van het effect in de tijd (gedurende het jaar) op de (bij)vangst worden gemaakt door het gebrek aan metingen per vistuigtype. Dit was oorspronkelijk wel een van de doelen. 
- $\quad$ Er kan geen ruimtelijke analyse worden gemaakt door het gebrek aan meerdere locaties per vistuigtype, maar dat was ook al bekend bij aanvang van de pilot.

- Er zijn veel data verzameld, waarvan duidelijke overzichten kunnen worden gemaakt, zoals voor (bij)vangstgegevens per vistuigtype en visreisdatum, en ook gepoold per vistuigtype over de duur van de hele pilot voor zowel VRS als de waarnemersreizen. Hieruit worden enkele conclusies getrokken.

\subsection{Vergelijking tussen gegevens van de vissers in het VRS en van waarnemers}

Een van de vragen die moet worden beantwoord is of er een substantieel verschil bestaat tussen de resultaten die zijn vergaard door de waarnemingen en door de vissers in het VRS.

VRS en het Billie programma van WMR zijn maar tot op beperkte hoogte met elkaar te vergelijken. Billie is ingericht voor een gedetailleerde en efficiënte registratie door waarnemers van alle trek/locatie gegevens, meetgegevens en allerlei andere biologische gegevens tijdens surveys en waarnemingsreizen. Vervolgens wordt dit opgeslagen op een manier die zeer efficiënt is voor de database van Wageningen Marine Research.

VRS is bedoeld om in het veld door ieder willekeurig persoon basis gegevens te laten registeren. Dit zijn basisgegevens en daarmee meteen beperkt bruikbaar voor wetenschappelijke doeleinden.

VRS is restrictief, doel is zo min mogelijk mogelijkheden te geven, zodat de gebruiker er zonder fouten mee kan werken. Extra soorten, extra gegevens vragen (lengte, gewicht, etc.) is erg lastig toe te voegen en vaak ook niet nodig. En dit is grotendeels terecht aangezien het fout ging toen er meer opties kwamen, en van de extra opties maar weinig correct zijn ingevoerd.

Voor een beperkte hoeveelheid gegevens kan VRS zeker goed werken. Voor het bereiken van voldoende bruikbare en betrouwbare resultaten uit de gegevens in VRS, zullen de gebruikers beter moeten worden onderwezen, met een demonstratie van de noodzaak van het consequent registreren. Waar mogelijk moeten in VRS allerlei velden verplicht worden gemaakt, alvorens de gegevens op kunnen worden geslagen. Zolang gebruikers de mogelijkheid hebben alle gegevens gecombineerd voor 1 positie te rapporteren, terwijl het meerdere fuiken etc. waren, worden wel data verkregen die een grof beeld van de vangst geven, maar geen data die bruikbaar gaat zijn in wetenschappelijk vergelijkingsstudies zoals voor onderhavige pilot werd gewenst.

VRS is beperkt bruikbaar voor wetenschappelijke vragen en kan niet dienen ter vervanging van waarnemersreizen. VRS is wel een geschikte tool voor vragen over visserijpraktijk, waaronder controle vragen van de NVWA.

\subsection{Ervaringen met VRS}

De ervaringen met de digitale visvangstregistratie door de vissers in het VRS van NatuurNetwerk, zijn dat de vissers het soms onduidelijk en bewerkelijk vonden om er mee te werken, terwijl er een enkele keer ook storingen in het VRS optraden.

Er zijn een aantal tekortkomingen geconstateerd bij de registratie van de gegevens in het VRS door de 4 deelnemende vissers. De belangrijkste tekortkomingen en daaraan gekoppelde mogelijke verbeteracties zijn:

- Niet consequent invoeren van ophalen en uitzetten van vangtuigen: soms niet, soms vaker per vangtuig (er wordt soms te vaak direct achter elkaar op dezelfde knop gedrukt). (Van Malsen, Blok)

- De sessie (batch) wordt niet afgesloten na elke visreis. Daardoor was er maar 1 batch van meerdere visreizen (Blok) 
- De posities voor uitzetten van elk uitgezet vistuig moeten worden genummerd terwijl dat niet altijd (volledig) gebeurt (bijv. Noord1, Noord2, West1, West2, enz.) (Smit)

- De vangstregistratie wordt niet afgesloten per vangtuig, maar voor een reeks vangtuigen achter elkaar (van Malsen)

- De juiste vissoort wordt niet altijd ingevoerd, terwijl de vissers die vissoort wel herkent, maar het keuzesysteem van het VRS werkte op dat moment niet. Het kan ook zijn dat de visser een vissoort probeert in te voeren die niet kan worden ingevoerd. Het is bijvoorbeeld voorgekomen dat de zwartbekgrondel dan wordt geregistreerd als baars.(Van Malsen)

- Een visreis is niet ingevoerd want het VRS systeem werkte toen niet (oorzaak: verouderde browser) (Smit)

- $\quad$ Na de eerste visperiode in het onderzoek, waarin de meeste tekortkomingen zijn geconstateerd, heeft WMR de vissers aangeraden dat ze de VRS handleiding nogmaals gaan lezen. Het bleek dat het omgaan met de VRS in de resterende visperiode veel beter ging. Voor de toekomst is voor 2 van de 4 vissers is een korte cursus, door NatuurNetwerk te geven, aan te raden.

- $\quad$ Een check en bewerking (opschonen) van de VRS gegevens door de onderzoekers is zeer belangrijk en onmisbaar en kostte veel tijd (Wageningen Marine Research).

\subsection{Bijvangst van vogels}

Duikvogels kunnen in potentie verstrikt raken in bepaalde vistuigtypen en dan verdrinken. In dit onderzoek zijn in korven geen vogels bijgevangen. In hokfuiken en schietfuiken zijn wel dode vogels aangetroffen en dit gaat om een beperkt aantal soorten, namelijk aalscholver, fuut en kuifeend.

De bijvangst van vogels in vistuigen, is een kennislacune, waarbij de algemene gedachte was dat dit in fuiken niet vaak voorkomt. In de Voortoets voor de Nb-wetvergunning voor dit onderzoek (Jongbloed, 2015) werd incidentele bijvangst van duikvogels niet uitgesloten, maar werd de omvang als dermate gering ingeschat dat deze een verwaarloosbaar zou hebben op de populaties van deze vogels. Significante effecten op de instandhoudingsdoelstellingen van vogels werden daarom niet verwacht. Met de gegevens die in onderhavig veldonderzoek zijn gegenereerd wordt die inschatting niet bevestigd.

Er is opvallend veel bijvangst van aalscholvers in hokfuiken opgetreden. De populatie bevindt zich recent ruim boven de doelstelling voor de populatieomvang. De trend van de populatie op het IJsselmeer in de periode 2003-2013 is positief. Er is geen bedreiging van de visserij met aangepaste hokfuiken in dit onderzoek voor de aalscholverpopulatie, mede door de geringe visserij-intensiteit. De relatief grote kans op bijvangst van aalscholvers in hokfuiken is wel een punt dat aandacht moet krijgen. De deelnemende hokfuikenvisser had de indruk dat de aalscholvers actief op de aangepaste hokfuiken af kwamen en deze mogelijk inzwemmen en daarna niet meer kunnen ontsnappen.

De fuut is een vogelsoort met een gemiddelde populatieomvang onder de doelpopulatie van het instandhoudingsdoel voor het IJsselmeer en heeft bovendien een afnemende trend. De staat van instandhouding van de landelijke populatie van de fuut is matig ongunstig. Deze soort is dus extra kwetsbaar voor effecten van het wolhandkrabvisserij onderzoek. Bij de bijvangst van enkele exemplaren kan men al overwegen de visserij waarmee de futen werden bijgevangen, te stoppen (zie Voortoets: Jongbloed, 2015). Er zijn in het onderzoek in totaal 13 futen bijgevangen. Dit gebeurde in 2 visreizen. Op 21 december 2016 dus aan het eind van de onderzoeksperiode werden 11 futen bijgevangen in aangepaste schietfuiken. Dit is een zorgpunt en er zou met de betrokken partijen besproken moeten worden of er nader onderzoek gedaan moet worden naar het risico van fuiken voor de wolhandkrabvisserij. Dit is dus zeker een punt van aandacht bij de eventuele opschaling van de visserij met hokfuiken. Bij de visserij met verlaagd staand want was de fuut al onder speciale aandacht vanwege het risico op bijvangst (Jongbloed, 2016).

Ook de kuifeend is extra kwetsbaar voor effecten van het wolhandkrabvisserij onderzoek. Deze soort heeft een behoudsdoelstelling voor het IJsselmeer. De populatie bevindt zich recent onder de doelstelling voor de populatieomvang. $\mathrm{Er}$ is geen betrouwbare indicatie te geven van de trend van 
de populatie op het IJsselmeer in de periode 2003-2013. Indien er tijdens de uitvoering van het wolhandkrabvisserij onderzoek substantiële bijvangst van kuifeenden wordt geconstateerd, kan de visserij met betreffende vistuig worden stilgelegd. Dit is dus een toepassing van het "hand aan de kraan principe". De geconstateerde bijvangst van 2 kuifeenden, die is opgetreden in dit onderzoek, is niet substantieel want deze is nog ruim onder de $1 \%$ mortaliteitsnorm van 29 exemplaren per jaar (zie Voortoets: Jongbloed, 2015). Men dient zich te bedenken dat de omvang van de visserij met aangepaste schietfuiken in dit onderzoek nog gering is, het probleem van de bijvangst van kuifeenden in schietfuiken kan wel een probleem worden bij opschaling.

\subsection{Vergelijking met ander onderzoek met aangepaste hokfuiken en schietfuiken}

IJsselmeervissers hebben eind 2007 tot begin 2008 een onderzoek uitgevoerd naar de effectiviteit en bijvangsten van een gerichte visserij op wolhandkrab met behulp van aangepaste grote fuiken en aangepaste schietfuiken (Leijzer et al. 2008). De omvang van deze bijvangsten was volgens hen zeer gering ten opzichte van de standaard schietfuikvisserij op aal. De verhouding wolhandkrab:bijgevangen schubvis $(\mathrm{kg})$ was ruwweg $1: 1$ (waarnemer) of 0,06 (zonder waarnemer) bij gebruik van aangepaste schietfuiken. De verhouding wolhandkrab:bijgevangen schubvis (kg) was ruwweg 1:1.6 (waarnemer) of $1: 1$ (zonder waarnemer) bij gebruik van aangepaste grote fuiken. In vergelijking hiermee wordt er voor de aangepaste schietfuiken van de VD94 in onderhavig onderzoek veel minder bijvangst van schubvis t.o.v. wolhandkrab (10\% t.o.v. 100\%) gevonden. Ook voor de hokfuiken wordt in ons onderzoek relatief minder schubvis bijgevangen (111\% t.o.v. 160\%). De netaanpassingen in het onderzoek van Leijzer et al. (2008) waren als volgt. De grote vuile fuiken hadden een ontsnappingsring voor vis in de laatste kub met hierin netwerk met een (gestrekte) maaswijdte tussen de 4,5 en $7 \mathrm{~cm}$. De schietfuiken hadden grote mazen (gestrekte maaswijdte tussen de 4,5 en $6 \mathrm{~cm}$ ) in de laatste kub. Deze aanpassingen verschillen van die in onderhavige onderzoek, waarin de hokfuik in de achterste kub geheel of deels (ruif) een maaswijdte heeft van tenminste 70 $\mathrm{mm}$, met een buis met een diameter van $200 \mathrm{~mm}$ en de schietfuik een maaswijdte van $70 \mathrm{~mm}$. Dit zou mede het verschil in bijvangst kunnen verklaren, maar dat is niet duidelijk omdat er nog andere factoren zijn die bijvangst kunnen beïnvloeden en die factoren kunnen heel verschillend zijn geweest in de perioden dat de beide experimenten plaatsvonden. Bult et al. (2007) toonden in een eerdere analyse naar de schubvis - aal vangst verhouding in schietfuiken aan dat tijd van het jaar, het weer en vislocatie een groot effect hebben op de bijvangstverhouding en samenstelling. Dergelijke effecten spelen hoogstwaarschijnlijk ook een rol bij de wolhandkrabvisserij.

Kampen (2014) heeft de bijvangst gemonitord in de wolhandkrabvisserij met aangepaste schietfuiken met een ruif of hele kub van $60 \mathrm{~mm}$ want achter in de schietfuiken in de periode oktober-november 2014. De maaswijdte is dus kleiner dan in dit onderzoek (70 $\mathrm{mm}$ ). De resultaten zijn redelijk vergelijkbaar met die van de aangepaste schietfuiken van de VD94 in ons onderzoek. De verhouding van de bijvangst van de 4 commerciële schubvissoorten t.o.v. gevangen wolhandkrab in de aangepaste schietfuiken van Kampen (2014) is 6.5\% en daarmee iets lager dan die in de aangepaste schietfuiken van de VD94 in dit onderzoek, terwijl die van de bijvangst van alle vissoorten samen t.o.v. gevangen wolhandkrab 52\% en iets hoger is. De schietfuiken van de GM29 wijken af door een relatief grotere bijvangst van zowel commerciële schubvissoorten als het totaal van alle vissoorten.

\subsection{Fuikenvisserij druk van onderzoek en visserijdruk van andere fuikenvisserij op het IJsselmeer}

Het aantal vergunde merken voor hokfuiken op IJsselmeer plus Markermeer in 2016 was 1733 volgens EZ/RVO, waarvan er 1012 ook een ontheffing voor de aalgesloten periode hadden. 
Het aantal vergunde merken voor schietfuiken op IJsselmeer plus Markermeer in 2016 was volgens EZ/RVO 3314 waarvan er 1459 ook een ontheffing voor de aalgesloten periode hadden.

Vergeleken met deze aantallen fuiken zijn de 42 hokfuiken en 325 schietfuiken in dit onderzoek geteste fuiken beperkt. Voor de hokfuiken is dit $2 \%$ van de niet aalgeslotenperiode en $4 \%$ van de aalgesloten periode. Voor de schietfuiken is dit $10 \%$ van de niet aalgeslotenperiode en $22 \%$ van de aalgesloten periode

\subsection{Schaalgrootte en bestanden van commerciële schubvis op het IJsselmeer}

Het onderzoek van Leijzer et al. (2008) naar gerichte visserij op wolhandkrab met behulp van aangepaste grote fuiken en aangepaste schietfuiken liet zien dat de bijvangst van schubvis bij de toen geldende inzet erg gering is, maar bij een volledige inzet substantieel (172 ton voor schietfuiken) kan zijn. Onder een meer realistischere aanname, waarbij maximaal 50\% van de merken wordt ingezet en er actief op wolhandkrab wordt gevist van oktober (november voor de grote fuiken) tot en met december (de migratie periode), dan zou dit neerkomen op respectievelijk 52 en 124 ton voor de schietfuiken en grote fuiken. Dit werd toen gezien als een relatief klein aandeel ten opzichte van de natuurlijke mortaliteit en schubvisvangst behorende bij de aalvisserij (zie sectie 3.4 en Bult et al. 2007).

\subsection{Beantwoording van de kennisvragen}

Bij de beantwoording van de kennisvragen worden eerst de deelvragen behandeld en daarna de hoofdvraag. De beantwoording van de hoofdvraag kan namelijk geheel worden gebaseerd op de antwoorden van de deelvragen.

1 en 2: Vangst van wolhandkrab en bijvangst van vis (omvang, soortensamenstelling, lengteverdeling)

$\mathrm{Er}$ is veel inzicht verkregen in de vangst van wolhandkrab en de omvang, soortsamenstellingen en lengteverdeling van de bijvangst van vis. Dit is verkregen uit de visserij met relatief weinig vistuigtypen (korf, hokfuik, schietfuik) en weinig schepen (WON1, EH22, VD94, GM29) in een lange vis periode, die was toegestaan gedurende bijna een jaar. Er zijn veel bruikbare gegevens verzameld. De vangst aan wolhandkrab en vis per visserijinspanning verschilde sterk tussen de vistuigtypen. Er worden veel schubvissoorten bijgevangen, waarbij er slechts enkele soorten zijn die in kwantitatieve zin, zowel aantal als gewicht, de bijvangst grotendeels bepalen. Dit zijn baars, snoekbaars, blankvoorn, bot, pos, zwartbekgondel. Daarvan zijn er bij elk van de 4 onderzochte vistuig-schip combinaties slechts steeds 2 vissoorten die de bijvangst domineren. De commerciële schubvissoorten baars, snoekbaars, blankvoorn hebben alleen bij de hokfuiken een belangrijk aandeel in de totale bijvangst. Met korven en hokfuiken wordt bijna alleen kleine vis bijgevangen, terwijl met schietfuiken ook veel grotere vis wordt bijgevangen.

\section{3: Verhouding tussen bijvangst van vis en vangst van wolhandkrab}

De verhouding tussen de bijvangst van vis en de vangst van wolhandkrab is berekend voor alle 4 vistuig-schip combinaties. Hierbij kwamen grote verschillen naar voren tussen deze combinaties. De bijvangst van vis relatief ten opzichte van wolhandkrab is het grootste in hokfuik en schietfuik van de GM29. De bijvangst is het kleinste in korven. De bijvangst is intermediair in de schietfuiken van VD94. Er wordt een groot verschil in bijvangst geconstateerd tussen de schietfuiken van de VD94 en de GM29. Er zijn twee verschillen tussen de beide schietfuik-schip combinaties die een grote rol bij dit verschil zouden kunnen spelen. Circa de helft van de schietfuiken van de GM29 had een andere netaanpassing, namelijk een grootmazige ruif in plaats van een grootmazige achterste kub. Wellicht dat de ontsnapping van vis beperkter is in een ruif vanwege de beperkte afmeting van die ruif. Een 
ander verschil betreft de vislocaties met de daaraan gekoppelde verschillen in dichtheden van wolhandkrab, schubvis, waterdiepte, e.d.. Dit zijn echter alleen veronderstellingen.

\section{4: Bijvangst van vogels}

Er is belangrijk inzicht verkregen in de bijvangst van vogels. Er trad namelijk bijvangst van een aanzienlijk aantal vogels op in hokfuiken en schietfuiken, terwijl van te voren niet werd verwacht dat de bijvangstkans in fuiken op het IJsselmeer zo groot zou kunnen zijn (Jongbloed, 2015). Het aantal waarnemingen is echter dermate gering om voldoende beeld te krijgen van de kans op bijvangst van vogels. Bijvangst van vogels in fuiken blijkt wel een reële bedreiging voor met name de instandhoudingsdoelstelling van de fuut te zijn, waarvoor nader onderzoek, dan wel maatregelen, worden aanbevolen.

Tijdens de visserij met aangepaste hokfuiken in dit onderzoek heeft de visser meerdere malen waargenomen dat zich veel duikende aalscholvers ophielden bij deze fuiken (persoonlijke mededeling R. Blok). Hij vermoedde dat aalscholver ook door de buis de fuik binnengaan om daar te foerageren op de bijgevangen vissen. Er werden bij het ophalen van de hokfuiken soms veel aangevreten vis gezien. Dit is waarschijnlijk veroorzaakt door de aalscholvers. Het zou kunnen dat aalscholvers ook gebruik maken van de buis om de fuik weer te verlaten. Er werd echter een aantal dode aalscholvers in de hokfuiken aangetroffen en de visser veronderstelt dat deze wel door de buis zijn binnengekomen, maar de buis niet meer hebben kunnen vinden om de fuik te verlaten. Het is niet duidelijk of de meeste aalscholver via de voorkant van de hokfuik of via de buis in de hokfuik terecht komen. Nader onderzoek met observaties met behulp van een onderwatercamera zou hier duidelijkheid over kunnen verschaffen.

\section{5: De invloed van seizoen en locatie op vangst en bijvangst}

Er is enig inzicht verkregen in de invloed van seizoen op vangst en bijvangst. Er waren geen grote verschillen tussen najaar, winter en voorjaar. Dit werd niet verwacht omdat algemeen bekend is dat de vangst van wolhandkrab meestal verreweg het grootste is in het najaar (Bakker \& Zaalmink, 2012). Echter de opzet en de omvang van dit onderzoek was te beperkt om harde conclusies te trekken. Voor de invloed van seizoenen binnen een jaar is monitoring gedurende een aantal jaren nodig, vanwege de variatie in bestanden van wolhandkrab en vissen. Er is slechts op 4 locaties in het IJsselmeer gevist en voor 2 van de 3 vistuigtypen op 1 locatie. Met schietfuiken is gevist op 2 locaties die meestal dichtbij elkaar lagen, waarbij wel grote verschillen in vangst en bijvangst werd gevonden. Om de eventuele invloed van regio's of locaties op vangst en bijvangst vast te kunnen stellen zal er per vistuigtype moeten worden gevist op meerdere locaties, die evenredig verdeeld zijn over het IJsselmeer. Vlakbij spuisluizen zal een groot deel van de bijgevangen vis tijdens het spuien weg spoelen. Hierbij wijken deze locaties sterk af van de rest van het IJsselmeer.

\section{6: De mate van overeenkomst tussen resultaten die zijn geregistreerd door waarnemingen van onderzoekers en door de vissers in het digitale visregistratiesysteem (VRS)}

De mate van overeenkomst tussen resultaten die zijn geregistreerd door waarnemers in hun eigen systeem en resultaten die door de vissers zijn ingevoerd in het digitale visregistratiesysteem (VRS) is redelijk voor de wolhandkrabvangst en over het algemeen matig voor bijvangst van vis, waarbij deze varieert per vissoort. Bij baars en aal schatten vissers de bijvangst hoger in dan de waarnemers. De correlatie is goed bij baars, blankvoorn en brasem; matig bij snoekbaars en aal en slecht bij bot. De verhouding tussen de bijvangst en de vangst verschilt tussen de beide registratiemethoden over het algemeen een factor 2, met een matige correlatie. VRS lijkt daarmee wel geschikt om een globaal te krijgen van vangst en bijvangst in de wolhandkrabvisserij, maar de afwijkingen met de waarnemers zijn soms aanzienlijk, o.m. vanwege het lagere detailniveau en daarmee is VRS niet geschikt voor wetenschappelijke doeleinden. Het geconstateerde verschil tussen waarnemers en vissers in dit onderzoek betreffende de schubvis:wolhandkrabvangstverhouding toont gelijkenis met de constatering van Bult et al. (2007) dat de schubvis:aalvangstverhouding in schietfuiken op het IJsselmeer door onderzoekers nog veel hoger werd ingeschat dan door vissers, namelijk 9:1 door onderzoekers en 4:1 door vissers. $\mathrm{Zij}$ vermoedden dat deze verschillen hoogstwaarschijnlijk zijn voortgekomen uit 
verschillen in schattingsmethoden: vissers schatten vooral op het oog, vanuit het onderzoek zijn de vangsten veelal gewogen en gemeten.

Hoofdvraag: Hoe selectief zijn nieuwe en aangepaste vistuigtypen voor de wolhandkrabvisserij op het IJsselmeer?

Alle 3 vistuigtypen zijn selectief voor de vangst van wolhandkrab, maar in verschillende mate. De verschillen zijn soms groot, maar zijn niet statistisch getoetst, omdat de opzet van het onderzoek zich daarvoor niet leende. De vraag blijft echter of deze selectiviteit voldoende of acceptabel is. Er zijn echter geen objectieve criteria voor een acceptabel niveau van selectiviteit van vistuigen.

In dit verband is wel relevant te noemen dat het Ministerie van LNV aan de PO IJsselmeer een brief heeft geschreven in 2006, waarin staat dat de verhouding bijvangst:aal maximaal 4:1 mag zijn om acceptabel te zijn voor visserij op schietfuiken (19:04:2006; Viss 06/2051).

We kunnen mede daarom voorstellen de volgende criteria te kiezen voor de verhouding tussen de bijvangst van alle schubvis ten opzichte van wolhandkrab (WHK) op basis van het gewicht:

- Klein: bijvangst vis : vangst WHK $<1$

- Matig: bijvangst vis : vangst WHK tussen 1 en 4

- Groot: bijvangst vis : vangst WHK $>4$

Hierbij zouden de categorieën klein en matig als acceptabel kunnen worden beschouwd.

Uitgaande van de metingen van de waarnemers is de bijvangst klein in korven, matig in hokfuiken, en klein tot groot in schietfuiken. Uitgaande van de registraties van de vissers is de bijvangst klein in korven, klein in hokfuiken, en klein tot matig in schietfuiken. De oorzaak van het grote verschil in de bijvangst tussen de twee schietfuik-schip combinaties is niet duidelijk. Mogelijk is een belangrijke oorzaak dat de schietfuiken met de grofmazige ruif in de achterste kub voor de ontsnapping van bijgevangen vissen veel minder effectief zijn geweest dan de schietfuiken met een achterste kub die geheel uit grofmazig netwerk bestaat.

\subsection{Aanbevelingen}

De resultaten laten de effectiviteit zien van een aantal verbetermogelijkheden zoals die in deze studie zijn onderzocht. Bij de bespreking van de resultaten met de deelnemende vissers bleek dat er nog veel aanvullende ideeën zijn en dus ruimte voor verdergaande verbetering en innovatie. Deze aanvullende ideeën worden hieronder benoemd.

\section{Keerwant in fuiken voor reductie van bijvangst van vogels}

Het risico op de bijvangst van duikvogels in hokfuiken en schietfuiken zou waarschijnlijk sterk kunnen worden gereduceerd met de toepassing van een grootmazige (bijvoorbeeld 100 of 140 mm) keerwant. Bij de fuikenvisserij in de kustwateren is een keerwant in fuiken al verplicht gesteld om daarmee de bijvangst van zeehonden en duikvogels te voorkomen. Bult et al. (2007) hebben de invloed van een keerwant ( $85-100 \mathrm{~mm}$ ) getest op bijvangst van vis in schietfuiken voor de aalvisserij op het IJsselmeer. De bijvangst van kleine en grote vis bleek aanzienlijk te worden gereduceerd.

In plaats van een keerwant zouden draden voorin de fuik kunnen worden gespannen. De verwachting is dat deze draden wel de duikvogels, maar niet de wolhandkrabben afschrikken om de fuik binnen te gaan. Dit zou experimenteel getest kunnen worden.

Draden die worden gespannen aan de buitenzijde van de ontsnappingsbuis zouden duikvogels, zoals aalscholvers, kunnen afschrikken door de buis de fuik binnen te komen.

De bevestiging van afschriklinten aan de palen van hokfuiken zou een effectieve mitigerende maatregel voor vogels kunnen zijn.

Nader onderzoek met onderwatercamera's kan worden aanbevolen om het gedrag van aalscholvers bij de hokfuiken, met en zonder de bovengenoemde mitigerende maatregelen, te onderzoeken. 
Aanpassingen van hokfuiken voor reductie van bijvangst van schubvis

De overleving van schubvis kan worden verbeterd met een opvangzak waarin de vangst wordt geleegd en de kleine schubvis kan ontsnappen. Dit is een alternatief voor de overlevingsbun.

Met de toepassing van een ruif (maaswijdte $70 \mathrm{~mm}$ ) aan de bovenkant en de onderkant van het middelste gedeelte van de hokfuik kan de daar zich soms massaal ophopende kleine schubvis makkelijker ontsnappen.

Diameter van de ontsnappingsbuis verkleinen van $20 \mathrm{~cm}$ naar $6 \mathrm{~cm}$, waardoor aal nog wel kan ontsnappen, maar er minder wolhandkrab ontsnapt (aangedragen door Rinke Blok). Het nadeel kan zijn dat grotere schubvis dan niet meer kan ontsnappen.

\section{Aanpassingen van schietfuiken voor reductie van bijvangst van schubvis}

Schietfuiken met een achterste kub die geheel uit grofmazig netwerk bestaan, zijn voor de beoogde ontsnapping van schubvis wellicht veel effectiever dan schietfuiken met de grofmazige ruif in de achterste kub. Het is echter wel belangrijk te controleren of de mazen van de achterste kub na het schieten van de fuiken wel voldoende open staan om daarmee de ontsnapping van kleine schubvis voldoende mogelijk te maken. Zo nodig moet de constructie van het netwerk worden aangepast om het doel wel te bereiken.

Met de toepassing van een ruif (maaswijdte $70 \mathrm{~mm}$ ) aan de bovenkant en de onderkant van het middelste gedeelte van de schietfuik kan de daar zich soms massaal ophopende kleine schubvis makkelijker ontsnappen.

\section{Testen van korven op andere locaties}

Met de korven wordt in absolute en relatieve zin zeer weinig bijgevangen. Volgens de korvenvisser is er hierbij nauwelijks verschil in bijvangst tussen de $6 \mathrm{~cm}$ en $7 \mathrm{~cm}$ ruif. Het is mogelijk dat de vislocatie een grote rol heeft gespeeld bij deze resultaten. Er is gevist vlakbij de spuisluizen waardoor er waarschijnlijk veel bijgevangen vis is weggespoeld (persoonlijke mededeling M. van Malsen). De bijvangst in korven zou groter kunnen zijn op locaties die niet bij spuisluizen, op minder dynamische locaties, staan. Dit is echter niet getest in dit onderzoek en kan worden aanbevolen.

\section{Opschaling van wolhandkrabvisserij}

De mogelijke opschaling van visserij met korven en fuiken op wolhandkrab behoefde in dit project niet te worden onderzocht. Dit is wel een interessante vraag, maar complex om te beantwoorden. De huidige of recente omvang van de IJsselmeer bestanden van wolhandkrab, de commerciële schubvissoorten en de overige vissoorten is namelijk niet bekend. Dan is het ook niet mogelijk om in te schatten welk aandeel de bijvangst van deze soorten in de wolhandkrabvisserij kan uitmaken van de bestanden. De vangstadviezen van de visserij op schubvis in het IJsselmeer worden namelijk gedaan met de data gelimiteerde benadering (DLS) (Tien et al., 2015; 2017) waarvoor geen absolute bestanden worden gebruikt gebaseerd op analytische bestandschattingen. Leijzer et al. (2008) hebben overigens wel een berekening gemaakt voor het effect op bijvangst van schubvis door de opschaling van wolhandkrabvisserij met fuiken in het IJsselmeer. Zij hadden daar toentertijd wel voldoende gegevens voor beschikbaar. Wij adviseren vooral de vangsten en de bijbehorende inspanning goed te registreren om daarmee op termijn te kunnen komen tot een optimaal beheer van de wolhandkrab.

Hoe verder? Adaptief beheer \& systematische verbetering

Wij adviseren de hierboven genoemde verbetermogelijkheden verder te verkennen en (als bewezen effectief) ook in de praktijk te benutten. De aanpak hiervan zou aan kunnen sluiten en meegenomen kunnen worden bij de "Plan B" benadering van de IJsselmeervissers, waarvoor de Staatssecretaris recent groen licht heeft gegeven - onder voorwaarden.

Dit betekent een aanpak van continue verbetering via "adaptief beheer": jaarlijks bepalen welke volgende verbeterstappen mogelijk zijn en kansrijk lijken; onderzoeken/door ontwikkelen (onder een onderzoekvergunning) van deze verbetermogelijkheden; en implementeren van daadwerkelijke verbeteringen. 


\section{$7 \quad$ Kwaliteitsborging}

Wageningen Marine Research beschikt over een ISO 9001:2008 gecertificeerd kwaliteitsmanagementsysteem (certificaatnummer: 187378-2015-AQ-NLD-RvA). Dit certificaat is geldig tot 15 september 2018. De organisatie is gecertificeerd sinds 27 februari 2001. De certificering is uitgevoerd door DNV Certification B.V. 


\section{$8 \quad$ Literatuur}

Bakker, T. \& W. Zaalmink (2012): De wolhandkrab, een Hollandse exoot; Een marktverkenning. LEIrapport 2012-006.

Bult, T.P., G. Aarts, J. Kampen \& T.B. Leijzer (2007): Bijvangsten in schietfuiken op het IJsselmeer. Imares en ATKB, Rapport nummer C125/07.

Czerniejewski, P. (2010): Changes in condition and in carapace length and width of the Chinese mitten crab (Eriocheir sinensis H. Milne Edwards, 1853) harvested in the Odra River estuary in 19992007. Oceanological and Hydrobiological Studies. International Journal of Oceanography and Hydrobiology Vol. XXXIX, No.2.

Heinen, A. (2012): Onderzoek naar bijvangsten aan aal in aangepaste hokfuiken en schietfuiken. Verslag van een proef. CVB.

Jongbloed, R.H. (2015): Voortoets bij de aanvraag van een Nb-wetvergunning voor onderzoek wolhandkrabvisserij op het IJsselmeer. IMARES rapport C149/15.

Jongbloed R.H. (2016): Futen en schelpdieren op het IJsselmeer in verband met te vermijden effecten door wolhandkrabvisserij. Wageningen Marine Research. Wageningen University \& Research Rapport 120/16.

Kampen, J. (2014): Rapport monitoring bijvangst krabbenvisserij IJsselmeer. Rapport van ATKB. Kenmerk: 20141022/brf03-definitief, d.d. 2 december 2014.

Kampen J. (2015): Onderzoek naar de bijvangst in laag staand want voor de wolhandkrabbenvisserij in het IJsselmeer. Rapport van ATKB. Kenmerk: 20150249/rap01-concept, 2 april 2015.

Leijzer, T.,B., E. Schram, J.W. van der Heul \& T. Bult (2007): Een verkenning naar de mogelijkheden voor opslag van levende wolhandkrab. IMARES rapport C089/07.

Leijzer, T.B., G.M. Aarts \& J. Kampen (2008): Gerichte visserij op wolhandkrab in het IJsselmeer, een onderzoek naar vangstmethoden en bijvangsten. Imares-rapport C088/08.

Ministerie van LNV (2009): Aanwijzingsbesluit IJsselmeer (gebied 72). Programmadirectie Natura 2000. PDN/2009-072.

Ministerie van EZ (2012): Wijzigingsbesluit IJsselmeer. Programmadirectie Natura 2000. PDN/201072. IJsselmeer (wijziging).

Soes, D.M., P.W. van Horssen, S. Bouma \& M.T. Collembon (2007): Chinese wolhandkrab; Een literatuurstudie naar ecologie en effecten. Rapport 07-234. Bureau Waardenburg.

Tien, N.S.H., T. van der Hammen \& R. van Hal (2015): Vangstadviezen voor snoekbaars, baars, blankvoorn, brasem in het IJsselmeer en Markermeer. IMARES rapport C045/15.

Tien, N., T. van der Hammen, P. de Vries, E. Schram \& J. Steenbergen (2017): Inspanningsadviezen voor snoekbaars, baars, blankvoorn en brasem in het IJssel- en Markermeer voor het visseizoen 2017 - 2018; Wageningen Marine Research Wageningen UR (University \& Research centre), Wageningen Marine Research rapport C018/17, 100 blz. https://doi.org/10.18174/410436

Van Hal, R. \& R. Jongbloed (2015): Protocol onderzoek wolhandkrabvisserij op het IJsselmeer. 29 december 2015. Conceptrapport IMARES. 


\section{Verantwoording}

Rapport C057/17

Projectnummer: 4318100039, 4318200021, 4318100131

Dit rapport is met grote zorgvuldigheid tot stand gekomen. De wetenschappelijke kwaliteit is intern getoetst door een collega-onderzoeker en het verantwoordelijk lid van het managementteam van Wageningen Marine Research

Akkoord:

Michiel Kotterman

Onderzoeker

Handtekening:

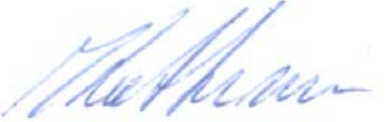

Datum:

$15-09-2017$

Akkoord:

Drs. J. Asjes

MT-Lid Integratie

Handtekening:

Datum:

31-07-2017 


\section{Bijlage 1 Antwoordformulier bij de brief Inventarisatie pilot experiment wolhandkrabvisserij op IJsselmeer}

Vraag- en antwoordformulier bij de brief Inventarisatie pilot experiment wolhandkrabvisserij op IJsselmeer

Betreft bijlage bij brief EZ met kenmerk RVO-VIR / 15078005.

\begin{tabular}{|l|l|}
\hline Naam Vergunninghouder & \\
\hline Vergunninghouder/-nummer & \\
\hline Kenteken vaartuig & \\
\hline Adres & \\
\hline Postcode & \\
\hline Plaats & \\
\hline Telefoonnummer & \\
\hline Emailadres & \\
\hline Datum & \\
\hline
\end{tabular}

\begin{tabular}{|c|c|c|}
\hline & Vragen & $\begin{array}{l}\text { Antwoorden (aankruisen en tekstueel } \\
\text { invullen) }\end{array}$ \\
\hline 1 & $\begin{array}{l}\text { Heeft u belangstelling voor deelname aan } \\
\text { het pilot experiment wolhandkrabvisserij? }\end{array}$ & $\begin{array}{l}\square \text { ja (de vragen hieronder verder invullen) } \\
\square \text { nee (u hoeft dan de vragen hieronder niet meer } \\
\text { in te vullen) }\end{array}$ \\
\hline 2 & $\begin{array}{l}\text { Welke type(en) aanpassing(en) aan } \\
\text { vistuigen voor pilot experiment } \\
\text { wolhandkrabvisserij wilt u toepassen? } \\
\text { Duidt deze aan d.m.v. aankruisen van } \\
\text { een van de gegeven rubrieken. }\end{array}$ & $\begin{array}{l}\square \text { aanpassingen aan staandwant } \\
\square \text { aanpassingen aan fuik: schietfuik } \\
\square \text { aanpassingen aan fuik: hokfuik } \\
\square \text { nieuw type tuig: platliggend net } \\
\square \text { nieuw type tuigen: krabben- of kreeftenkorf } \\
\square \text { nieuw type tuigen: anders (graag hier } \\
\text { aanduiden) }\end{array}$ \\
\hline 3 & $\begin{array}{l}\text { Voeg een tekening en/of foto en zo } \\
\text { mogelijk meer details bij van het door u } \\
\text { voorgestelde aangepaste experimentele } \\
\text { vistuig voor wolhandkrabvisserij. }\end{array}$ & Graag als bijlage toevoegen. \\
\hline 4 & $\begin{array}{l}\text { Geef een omschrijving van het door u } \\
\text { voorgestelde aangepaste experimentele } \\
\text { vistuig voor wolhandkrabvisserij. }\end{array}$ & \\
\hline 5 & $\begin{array}{l}\text { Op welke wijze denkt u dat deze } \\
\text { aanpassingen bijdragen aan selectieve } \\
\text { wolhandkrabvisserij? Bijvoorbeeld: } \\
\text { - verlaging van de vangkans van }\end{array}$ & \\
\hline
\end{tabular}




\begin{tabular}{|l|l|l|}
\hline & $\begin{array}{l}\text { schubvis. } \\
\text { - meer ontwijking van het tuig door } \\
\text { schubvis door vergroting van de } \\
\text { zichtbaarheid van het materiaal, } \\
\text { - vergroting van de overlevingskans van } \\
\text { bijgevangen schubvis, } \\
\text { - etc. }\end{array}$ & \\
\hline 6 & $\begin{array}{l}\text { Wat is het aantal experimentele vistuigen } \\
\text { dat u wilt inzetten? }\end{array}$ & \\
\hline 7 & $\begin{array}{l}\text { Heeft u voorkeurlocaties waar u zou } \\
\text { willen vissen met experimenteel vistuig? } \\
\text { Deze graag aangeven op de kaart } \\
\text { IJsselmeer en Markermeer die is } \\
\text { bijgevoegd. }\end{array}$ \\
\hline
\end{tabular}

Aan de hier door u opgegeven informatie kunnen geen rechten worden ontleend, zoals ook beschreven in de brief.

Dit antwoordwoordformulier met de bijbehorende informatie kunt u voor 1 juli 2015 naar IMARES sturen per email, ruud.jongbloed@wur.nl, of per post middels de bijgevoegde antwoordenvelop (geen postzegel nodig) 


\section{Bijlage 2 Kaart van het IJsselmeer met indeling van de regio's}

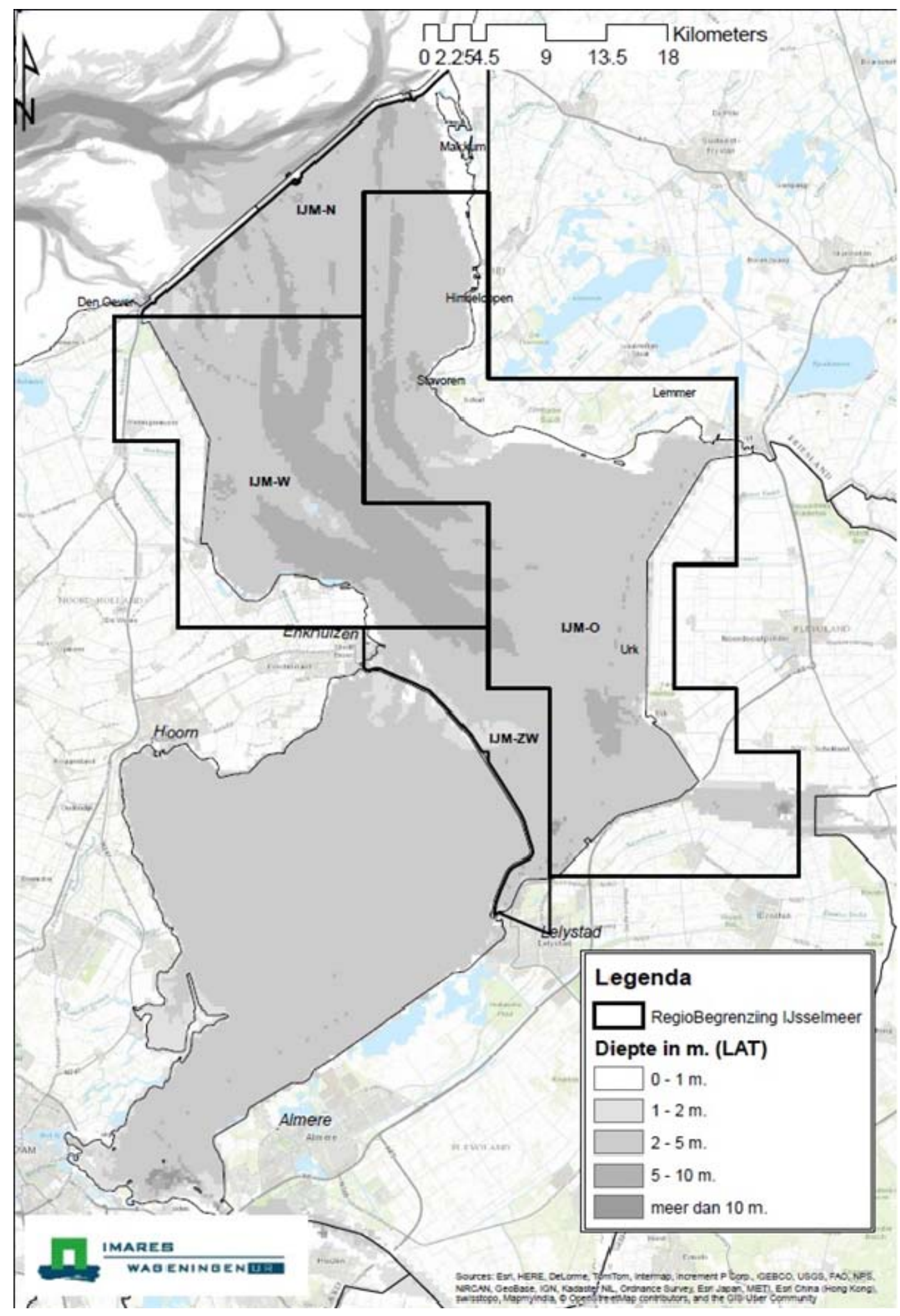




\section{Bijlage 3 Foto's van vistuigtypen in het wolhandkrabvisserij onderzoek}
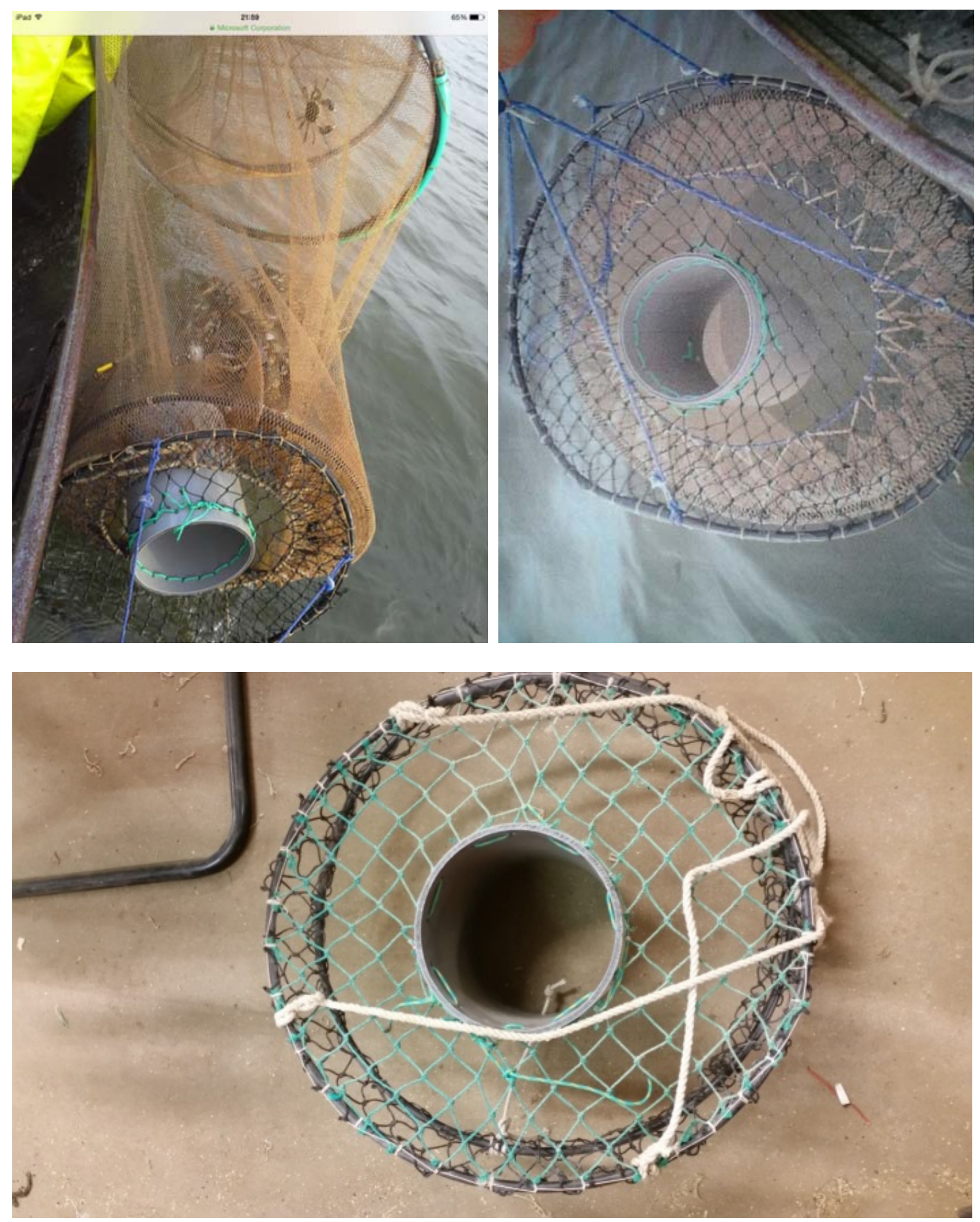

Hokfuik

Kub $70 \mathrm{~mm}$ of ruif $70 \mathrm{~mm}$ En buis horizontaal 

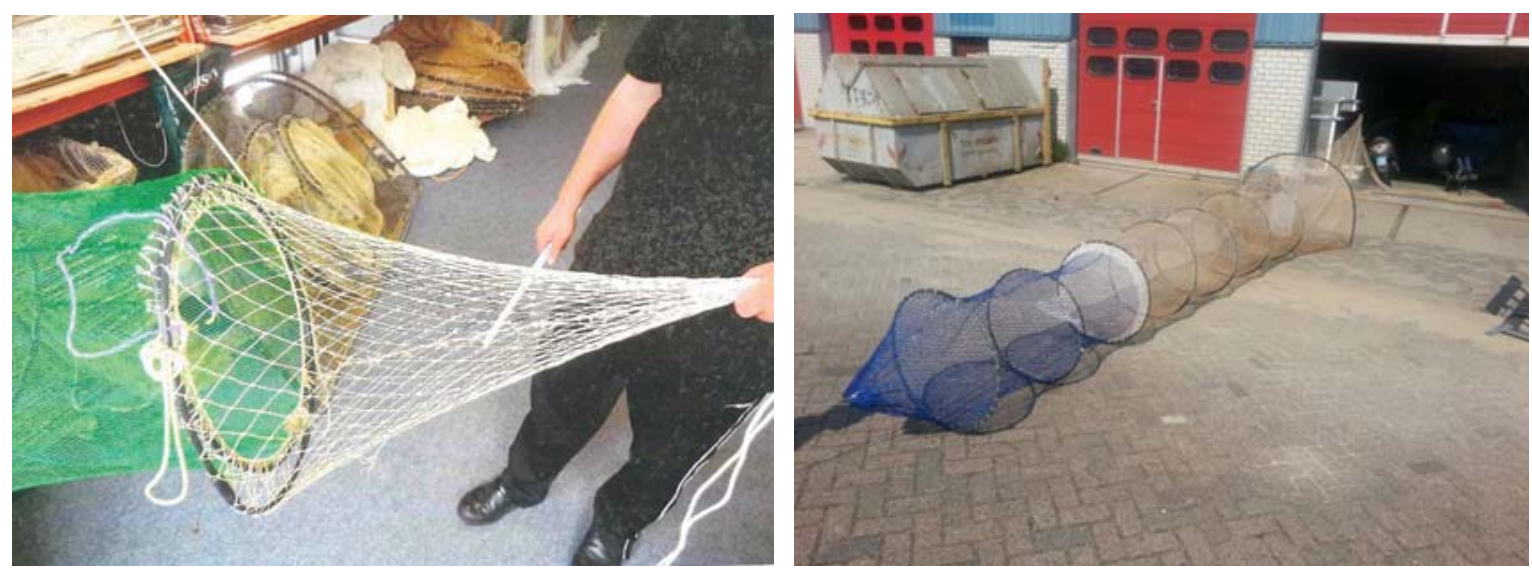

2

Schietfuik. Kub $70 \mathrm{~mm}$ of ruif $70 \mathrm{~mm}$, zonder buis
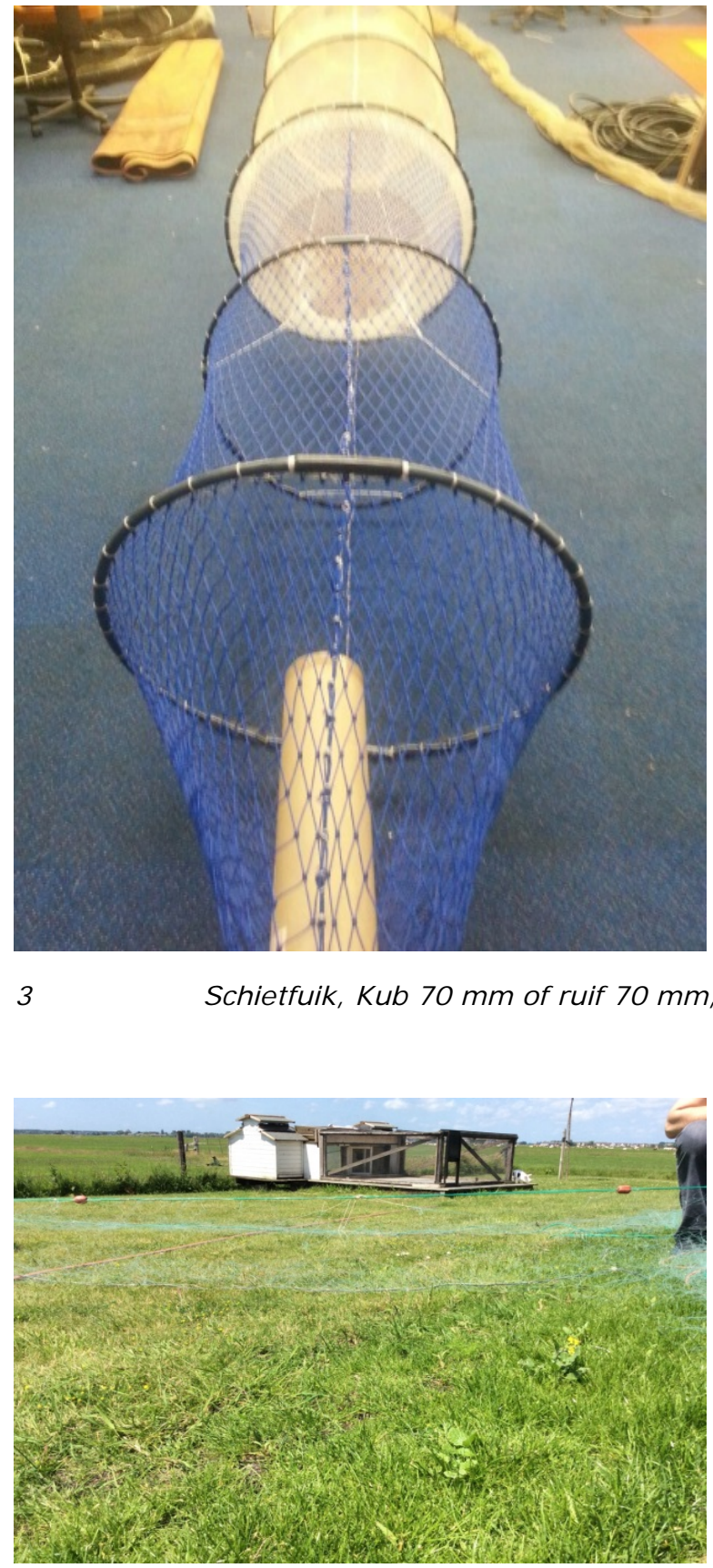


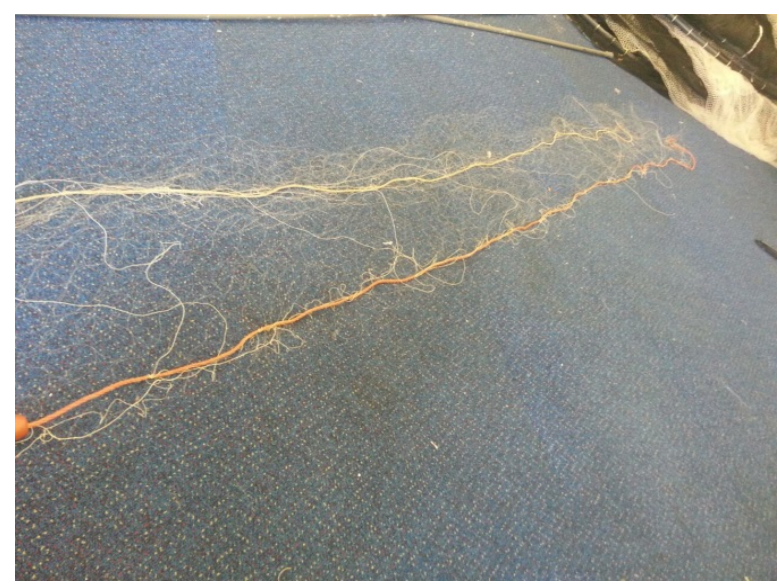

Platliggend net

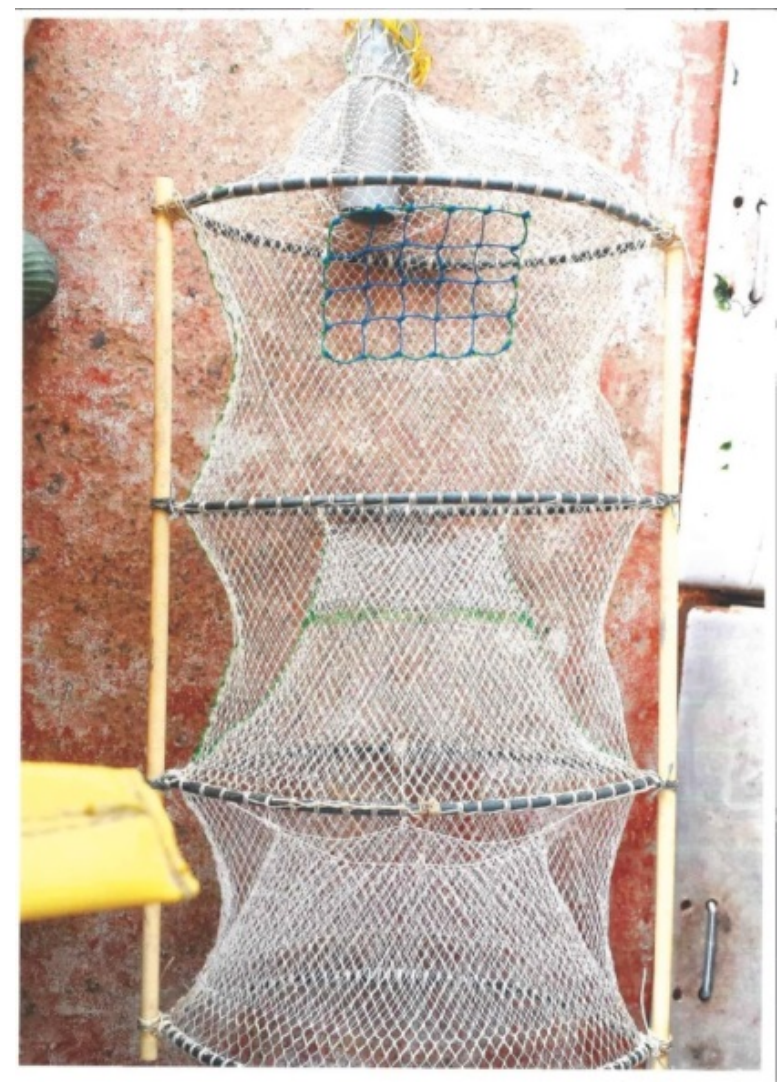

8

Korven (kubbentype) 


\section{Bijlage 4 Voorwaarden deelname onderzoek wolhandkrabvisserij IJsselmeer}

De volgende voorwaarden gelden voor dit onderzoek. Door inschrijving bevestigt de inschrijvende visser met deze voorwaarden in te stemmen en deze na te leven. Na de selectie ondertekent de vissers een contract met IMARES waarin de voorwaarden nogmaals worden bevestigd.

1. IMARES heeft alleen inschrijvingen in behandeling genomen die uiterlijk 21 september 2015 zijn ontvangen.

2. Het doen van een inschrijving betekent niet automatisch dat er een recht is op deelname aan het experiment. IMARES zal bij de selectie o.m. rekening houden met de uitvoerbaarheid en efficiëntie van het experiment.

3. De visser voert het bemonsteringsprogramma (o.a. gehele periode, locaties, type en aantal vistuigen, netlichtingen) uit, zoals dat vooraf is bepaald in het projectplan en houdt zich aan de voorwaarden die in de ontheffing op grond van de Visserijwet 1963 zijn opgenomen. Het projectplan beschrijft de vistuigtypen, het bemonsteringsprogramma, het controleprotocol en de sancties voor overtredingen.

4. De visser zal alleen de tuigen verplaatsen na uitdrukkelijke toestemming van IMARES.

5. De eigendomsrechten van de gegevens uit het experiment liggen bij IMARES en kunnen in geanonimiseerde vorm door IMARES openbaar worden gemaakt.

6. Als tijdens het experiment blijkt dat een bepaald vistuig naar het oordeel van IMARES aanzienlijk aal, schubvis of vogels bijvangt, bestaat de mogelijkheid dat het experiment naar dat tuig tussentijds wordt stopgezet door IMARES. Eventuele daaruit voortvloeiende kosten of schade zijn voor rekening van de visser.

7. De visser is visrechthebbende op het IJsselmeer en heeft voldoende visrechten (merkjes) voor de te testen vistuigen (m.u.v. nieuwe tuigen zoals platliggend net, korven en kooien). De $85 \%$ reductie op staandwantmerkjes is niet van toepassing op het aangepaste staandwant. De visser voert de visserij uit op eigen kosten.

8. Gevangen wolhandkrab mag de visser behouden en verkopen. Bijgevangen aal en onbeschadigde schubvis wordt onmiddellijk en levend teruggezet in hetzelfde water.

9. De visser werkt volledig mee aan controles van de daarvoor bij dit experiment door IMARES betrokken onafhankelijke controleurs die aangekondigd en onaangekondigd zullen controleren. Zij zullen aanlandingscontroles, controles tijdens visserijreizen van de visser en controle van de tuigen zonder aanwezigheid van de visser uitvoeren.

10. Van de vissers wordt verwacht dat ze professioneel en integer handelen. IMARES laat alleen vissers toe tot het experiment die een Verklaring Omtrent het Gedrag overleggen binnen een maand na aanvang van de visserij. Alle in te zetten medewerkers aan boord dienen een Verklaring Omtrent het Gedrag te kunnen overleggen. De kosten voor de aanvraag van de Verklaring Omtrent het Gedrag worden gedragen door de vissers.

11. De visser neemt deel aan een door IMARES te kiezen digitaal registratiesysteem en zorgt voor tijdige invoer daarin van tuigtypen en -locaties, visserijactiviteiten en overige onderzoeksdata. Te denken valt aan het registratiesysteem van Natuurnetwerk, zoals dat nu wordt gebruikt voor de visserij op wolhandkrab tijdens de aalgesloten tijd. De kosten voor het kunnen invoeren (het hebben van de licentie en een tablet of een smartphone en $50 \%$ van de kosten van een nieuw aan te schaffen licentie voor het gebruik van het systeem) zijn voor de visser.

12. De visser stemt ermee in dat het digitaal registratiesysteem toegankelijk is voor IMARES, de onafhankelijke controleurs die IMARES aantrekt en de ambtenaren, bedoeld in artikel 54a, van de Visserijwet 1963.

13. De visserij-reizen voor dit experiment zullen niet gecombineerd worden met andere visserijactiviteiten. Hierdoor is helder dat alle activiteiten en vangsten aan boord afkomstig zijn van het experiment.

14. Als voor of tijdens het experiment blijkt dat een visser deze spelregels of de aan de ontheffing verbonden voorwaarden niet naleeft, zal IMARES deze visser direct uitsluiten van verdere deelname aan het experiment. Eventuele kosten of schade voor de visser blijft voor rekening van de visser. Tevens zal IMARES melding doen van de uitsluiting aan de Minister van Economische Zaken. Deze zal de desbetreffende visser dan gedurende de periode van drie jaar volgend op de niet naleving uitsluiten van deelname aan ontheffingen voor ander onderzoek. 
Afhankelijk van de inschrijving, eventuele nieuwe inzichten en het beschikbare budget van het Ministerie van Economische Zaken kan de hier beschreven opzet van het projectplan worden aangepast. 


\section{Bijlage 5 Controle formulier voor wolhandkrabvisserij bijvangst schubvis}

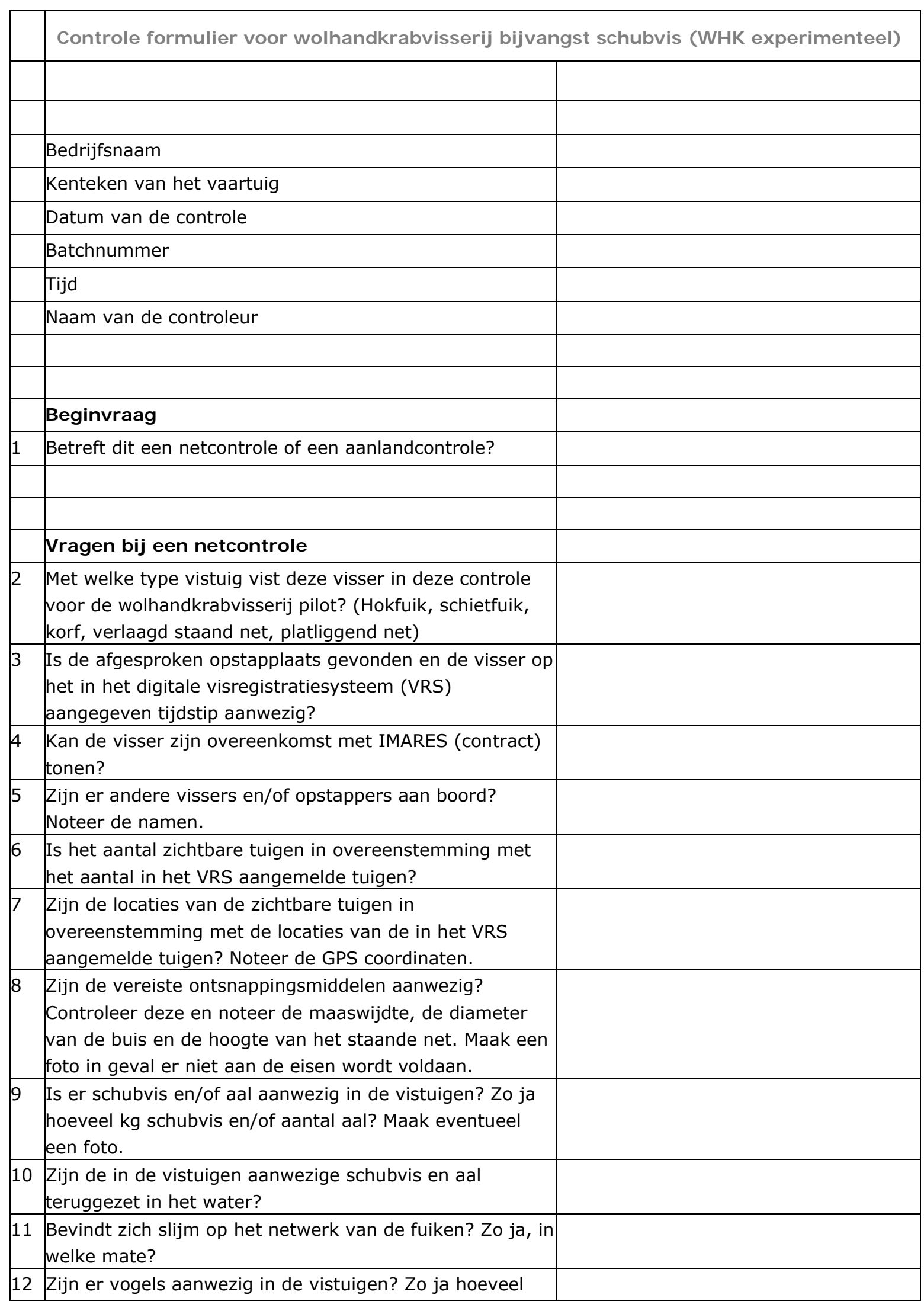




\begin{tabular}{|c|c|c|}
\hline & per vogelsoort? Maak dan een foto. & \\
\hline \multirow[t]{3}{*}{13} & Zijn er nog bijzonderheden geconstateerd? Zo ja, welke? & \\
\hline & & \\
\hline & Yragan hii oan a plandrontroll & \\
\hline 14 & $\begin{array}{l}\text { Met welke type vistuig vist deze visser in deze controle } \\
\text { voor de wolhandkrabvisserij pilot? (Hokfuik, schietfuik, } \\
\text { korf, verlaagd staand net, platliggend net) }\end{array}$ & \\
\hline 15 & $\begin{array}{l}\text { Is de afgesproken aanlandplaats gevonden en de visser } \\
\text { op het in het digitale visregistratiesysteem (VRS) } \\
\text { aangegeven tijdstip aanwezig? }\end{array}$ & \\
\hline 16 & $\begin{array}{l}\text { Kan de visser zijn overeenkomst met IMARES (contract) } \\
\text { tonen? }\end{array}$ & \\
\hline 17 & $\begin{array}{l}\text { Zijn er andere vissers en/of opstappers aan boord? } \\
\text { Noteer de namen. }\end{array}$ & \\
\hline 18 & $\begin{array}{l}\text { Is er op het moment van de aanlanding in de bun of } \\
\text { elders (bevestigd) aan boord schubvis en/of aal } \\
\text { aanwezig? Zo ja, hoeveel kg schubvis en/of welk aantal } \\
\text { aal? Maak dan een foto. }\end{array}$ & \\
\hline 19 & Zijn er nog bijzonderheden geconstateerd? Zo ja, welke? & \\
\hline
\end{tabular}




\section{Bijlage 6 Tijdschema wolhandkrabvisserij onderzoek volgens de vergunning en daadwerkelijk gevist}

Tabel A: Tijdschema voor het wolhandkrabvisserij onderzoek IJsselmeer volgens de vergunningen (ontheffing).

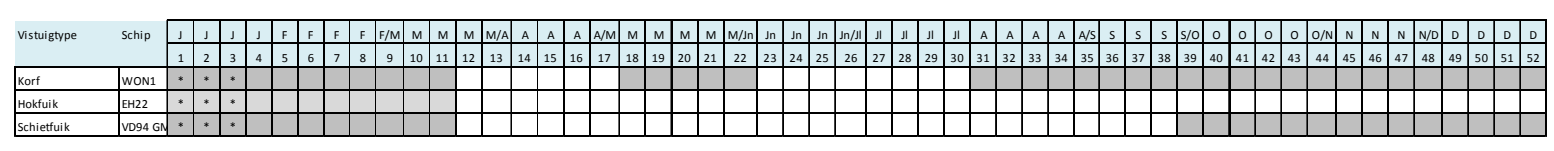

* visserij was wel toegestaan volgens de vergunningen, maar het contract was nog niet aangeboden aan de visser waardoor visserij in de pilot nog niet mogelijk was.

Tabel B: Tijdschema voor het wolhandkrabvisserij onderzoek IJsselmeer waarin daadwerkelijk is gevist.

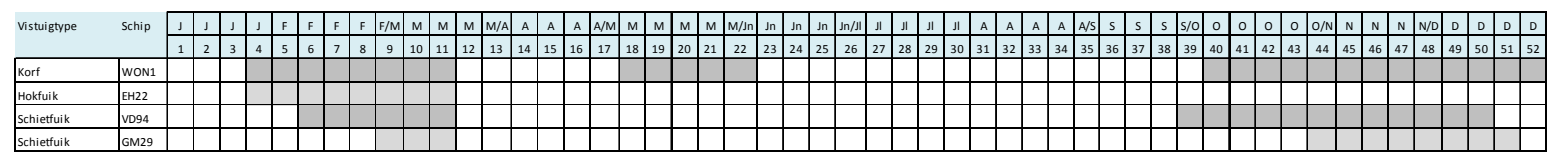




\section{Bijlage 7 Kenmerken ingezette korven}

Direct na de eerste keer uitzetten van de korven op 28 januari 2016 heeft Van Malsen (WON1) kenmerken van de korven en de waterdiepte doorgegeven:

\begin{tabular}{|c|c|c|}
\hline Kor & & waterdiept \\
\hline 1 & rond diameter $35 \mathrm{~cm}$. maaswijdte $10 \mathrm{~mm} \mathrm{(zwart)} \mathrm{met} \mathrm{ruif} 70 \mathrm{~mm}$ & 4.00 \\
\hline 2 & rechthoekig $56 \mathrm{~cm}$ breed en $20 \mathrm{~cm}$ hoog maaswijdte $11 \mathrm{~mm}$ (groen) met ruif $60 \mathrm{~mm}$ & 3.50 \\
\hline 3 & ovaal $48 \mathrm{~cm}$ breed en $25 \mathrm{~cm}$ hoog maaswijdte $11 \mathrm{~mm}$ ( zwart) met ruif $60 \mathrm{~mm}$ & 3.50 \\
\hline 4 & rond diameter $35 \mathrm{~cm}$ maaswijdte $9 \mathrm{~mm}$ ( groen ) met ruif $70 \mathrm{~mm}$ & 3.50 \\
\hline 5 & ovaal 48 breed en $25 \mathrm{~cm}$ hoog maaswijdte $11 \mathrm{~mm}$ ( wit ) met ruif $60 \mathrm{~mm}$ & 3.50 \\
\hline 6 & rechthoekig $40 \mathrm{~cm}$ breed en $20 \mathrm{~cm}$ hoog $10 \mathrm{~mm}$ ( zwart ) met ruif $60 \mathrm{~mm}$ & 3.50 \\
\hline 7 & rond diameter $35 \mathrm{~cm}$ maaswijdte $10 \mathrm{~mm}$ ( zwart ) met ruif $70 \mathrm{~mm}$ & 3.50 \\
\hline 8 & ovaal $48 \mathrm{~cm}$ breed en $25 \mathrm{~cm}$ hoog maaswijdte $11 \mathrm{~mm}$ ( wit ) met ruif $60 \mathrm{~mm}$ & 3.50 \\
\hline 9 & ovaal $48 \mathrm{~cm}$ breed en $25 \mathrm{~cm}$ hoog maaswijdte $10 \mathrm{~mm}$ ( zwart ) met ruif $60 \mathrm{~mm}$ & 3.50 \\
\hline 10 & rechthoekig $40 \mathrm{~cm}$ breed en $20 \mathrm{~cm}$ hoog maaswijdte $11 \mathrm{~mm}$ ( wit ) met ruif $60 \mathrm{~mm}$ & 4.00 \\
\hline 11 & ovaal $48 \mathrm{~cm}$ breed en $25 \mathrm{~cm}$ hoog maaswijdte $11 \mathrm{~mm}$ ( groen ) met ruif $60 \mathrm{~mm}$ & 4.00 \\
\hline 12 & rond diameter $35 \mathrm{~cm}$ maaswijdte $9 \mathrm{~mm}$ ( groen ) met ruif $70 \mathrm{~mm}$ & 4.00 \\
\hline 13 & rechthoekig $40 \mathrm{~cm}$ breed en $20 \mathrm{~cm}$ hoog maaswijdte $10 \mathrm{~mm}$ ( zwart) met ruif $60 \mathrm{~mm}$ & 4.00 \\
\hline 14 & ovaal $48 \mathrm{~cm}$ breed en $25 \mathrm{~cm}$ hoog maaswijdte $11 \mathrm{~mm}$ ( wit ) met ruif $60 \mathrm{~mm}$ & 4.50 \\
\hline 15 & rond diameter $35 \mathrm{~cm}$ maaswijdte $10 \mathrm{~mm}$ ( zwart ) met ruif $70 \mathrm{~mm}$ & 4.50 \\
\hline 16 & rechthoekig $40 \mathrm{~cm}$ breed en $20 \mathrm{~cm}$ hoog maaswijdte $11 \mathrm{~mm}$ ( wit ) met ruif $60 \mathrm{~mm}$ & 5.00 \\
\hline 17 & ovaal $48 \mathrm{~cm}$ breed en $25 \mathrm{~cm}$ hoog maaswijdte $10 \mathrm{~mm}$ ( zwart ) met ruif $60 \mathrm{~mm}$ & 5.00 \\
\hline 18 & rechthoekig 56 breed en $20 \mathrm{~cm}$ hoog maaswijdte $11 \mathrm{~mm}$ ( groen ) met ruif $60 \mathrm{~mm}$ & 5.20 \\
\hline 19 & ovaal $48 \mathrm{~cm}$ breed en $25 \mathrm{~cm}$ hoog maaswijdte $11 \mathrm{~mm}$ ( zwart ) met ruif $60 \mathrm{~mm}$ & 5.30 \\
\hline 20 & rond diameter $35 \mathrm{~cm}$ maaswijdte $9 \mathrm{~mm}$ ( groen ) met ruif $70 \mathrm{~mm}$ & 5.50 \\
\hline 21 & ovaal $48 \mathrm{~cm}$ breed en $25 \mathrm{~cm}$ hoog maaswijdte $11 \mathrm{~mm}$ ( wit ) met ruif 60 & 7.40 \\
\hline 22 & rechthoekig $40 \mathrm{~cm}$ breed en $20 \mathrm{~cm}$ hoog maaswijdte $10 \mathrm{~mm}$ ( zwart ) met ruif $60 \mathrm{~mm}$ & 8.00 \\
\hline 23 & ovaal $48 \mathrm{~cm}$ breed en $25 \mathrm{~cm}$ hoog maaswijdte $10 \mathrm{~mm}$ ( zwart ) met ruif $60 \mathrm{~mm}$ & 9.00 \\
\hline 24 & rond diameter $35 \mathrm{~cm}$ maaswijdte $9 \mathrm{~mm}$ ( groen ) met ruif $70 \mathrm{~mm}$ & 9.50 \\
\hline 25 & ovaal $48 \mathrm{~cm}$ breed en $25 \mathrm{~cm}$ hoog maaswijdte $11 \mathrm{~mm}$ ( wit ) met ruif $60 \mathrm{~mm}$ & 9.70 \\
\hline 26 & rond diameter $35 \mathrm{~cm}$ maaswijdte $10 \mathrm{~mm}$ ( zwart ) met ruif $70 \mathrm{~mm}$ & 9.50 \\
\hline 27 & ovaal $48 \mathrm{~cm}$ breed en $25 \mathrm{~cm}$ hoog maaswijdte $11 \mathrm{~mm}$ ( wit ) met ruif $60 \mathrm{~mm}$ & 7.30 \\
\hline 28 & ovaal $48 \mathrm{~cm}$ breed en $25 \mathrm{~cm}$ hoog maaswijdte $11 \mathrm{~mm}$ ( groen ) met ruif $60 \mathrm{~mm}$ & 6.00 \\
\hline 29 & ovaal $48 \mathrm{~cm}$ breed en $25 \mathrm{~cm}$ hoog maaswijdte $10 \mathrm{~mm}$ ( zwart ) met ruif $60 \mathrm{~mm}$ & 5.40 \\
\hline 30 & ovaal $48 \mathrm{~cm}$ breed en $25 \mathrm{~cm}$ hoog maaswijdte $11 \mathrm{~mm}$ ( wit ) met ruif $60 \mathrm{~mm}$ & 5.30 \\
\hline
\end{tabular}


Wageningen Marine Research

$\mathrm{T}+31(0) 317480900$

E: marine-research@wur.nl

www.wur.eu/marine-research

Visitors' address

- Ankerpark 271781 AG Den Helder

- Korringaweg 7, 4401 NT Yerseke

- Haringkade 1, 1976 CP IJmuiden
Wageningen Marine Research is the Netherlands research institute established to provide the scientific support that is essential for developing policies and innovation in respect of the marine environment, fishery activities, aquaculture and the maritime sector.

\section{Wageningen University \& Research:}

is specialised in the domain of healthy food and living environment.

\section{The Wageningen Marine Research vision}

'To explore the potential of marine nature to improve the quality of life'

\section{The Wageningen Marine Research mission}

- To conduct research with the aim of acquiring knowledge and offering advice on the sustainable management and use of marine and coastal areas.

- Wageningen Marine Research is an independent, leading scientific research institute

Wageningen Marine Research is part of the international knowledge organisation Wageningen UR (University \& Research centre). Within Wageningen UR, nine specialised research institutes of the Stichting Wageningen Research Foundation have joined forces with Wageningen University to help answer the most important questions in the domain of healthy food and living environment. 